\title{
Discovery of novel celastrol derivatives as Hsp90-Cdc37 interaction disruptors with antitumour activity
}

Na Li $i^{\delta}$, Manyi Xu ${ }^{\delta}$, Bing Wang, Zhixian Shi, Zihao Zhao, Yunqing Tang, Xinyue Wang, Jianbo Sun*, and Li Chen*

State Key Laboratory of Natural Medicines, Department of Natural Medicinal Chemistry, School of Traditional Chinese Pharmacy, China Pharmaceutical University, 24 Tong Jia Xiang, Nanjing 210009, People's Republic of China

\section{Contents:}

1. Structural characterization of the compounds $\left({ }^{1} \mathrm{H}\right.$ NMR, ${ }^{13} \mathrm{C}$ NMR, ESI/HRMS spectrum of the final compounds $\mathbf{1 - 4 8}, \mathbf{4 1 - H}$ and 41-Bio); 2 . The synthetic route of compound 41-H; 3. HPLC analysis of target compounds 
1. Spectral data.

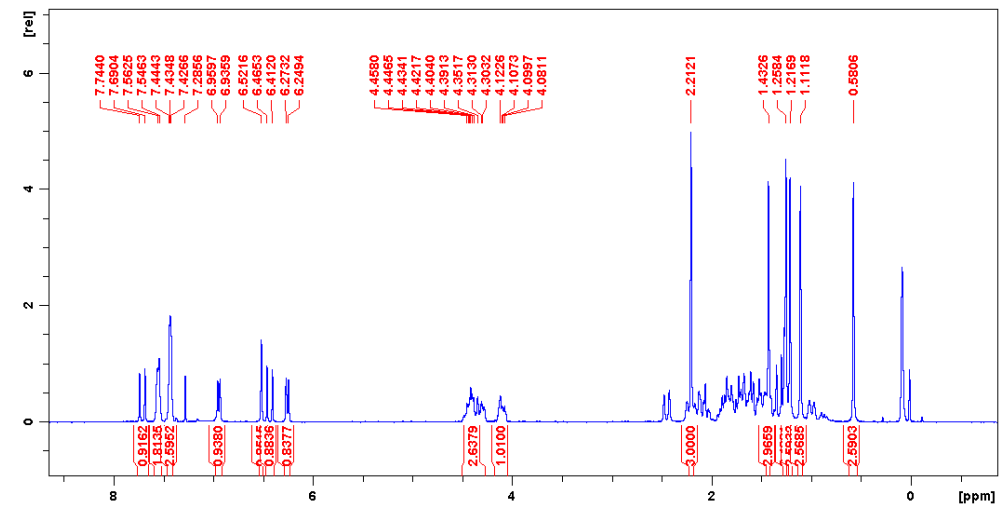

Fig. S1 ${ }^{1} \mathrm{H}$ NMR spectrum of $1\left(300 \mathrm{MHz}\right.$ in $\left.\mathrm{CDCl}_{3}\right)$

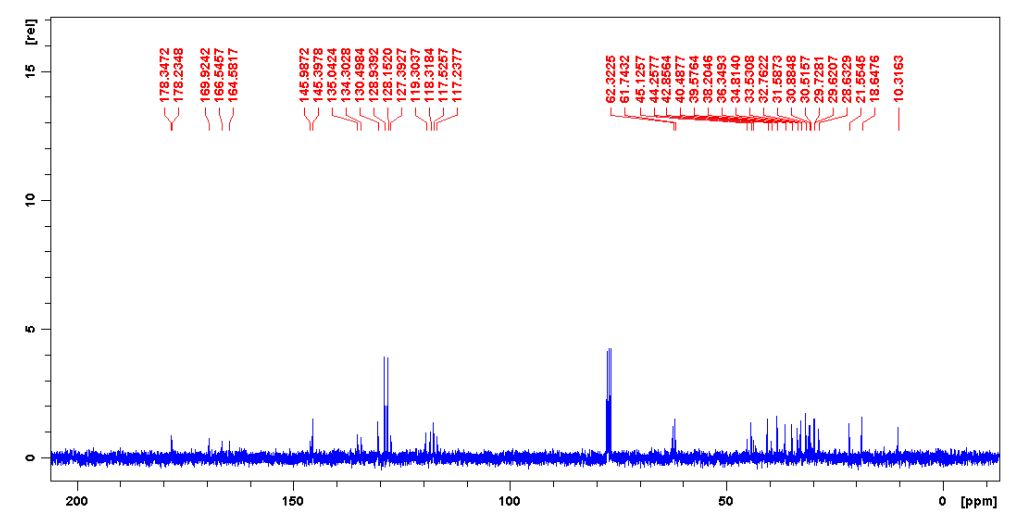

Fig. S2 ${ }^{13} \mathrm{C}$ NMR spectrum of $1\left(75 \mathrm{MHz}\right.$ in $\left.\mathrm{CDCl}_{3}\right)$

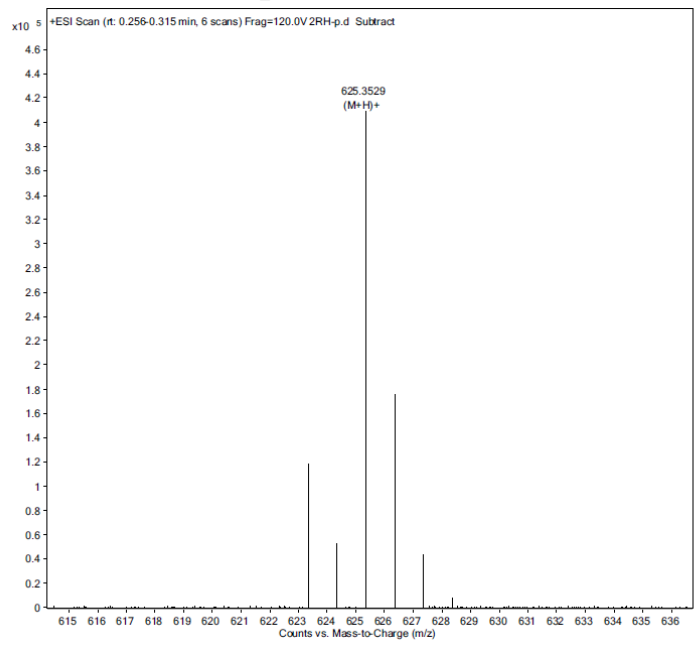

Spectrum Identification Results: + Scan (rt: 0.256-0.315 min) Sub - 2RH-p.d (2RH-p.d)

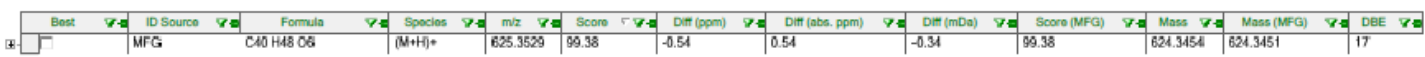

Fig. S3 ESI/HREMS spectrum of 1 


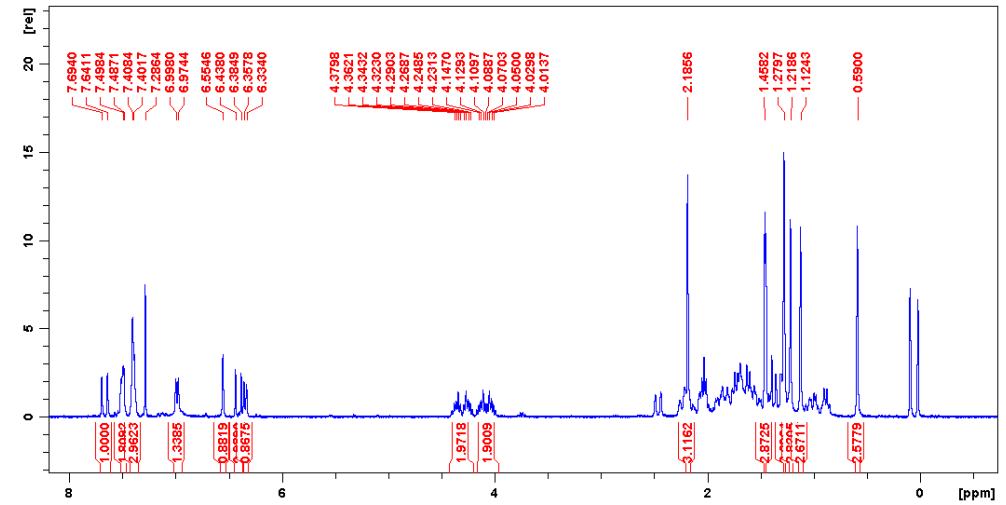

Fig. S4. ${ }^{1} \mathrm{H}$ NMR spectrum of $2\left(300 \mathrm{MHz}\right.$ in $\left.\mathrm{CDCl}_{3}\right)$

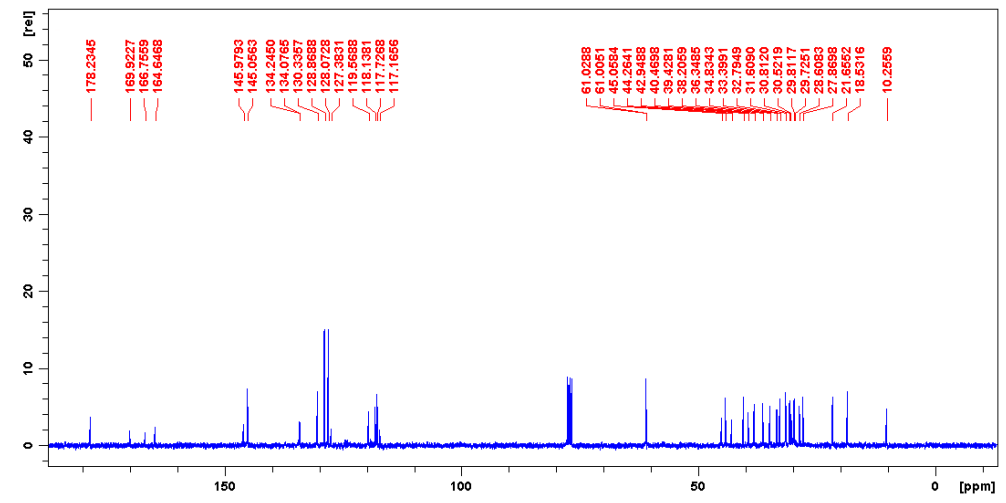

Fig. S5. ${ }^{13} \mathrm{C}$ NMR spectrum of $2\left(75 \mathrm{MHz}\right.$ in $\left.\mathrm{CDCl}_{3}\right)$

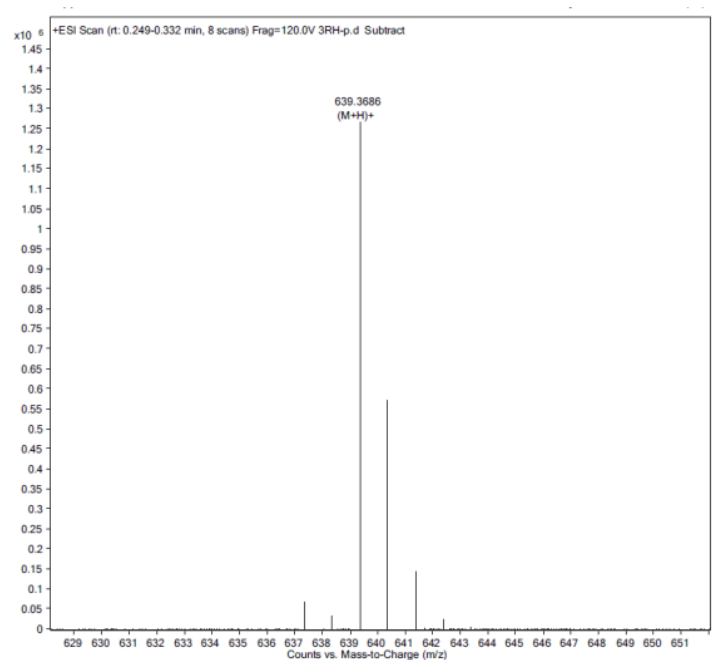

Spectrum Identification Results: + Scan (rt: 0.249-0.332 min) Sub - 3RH-p.d (3RH-p.d)

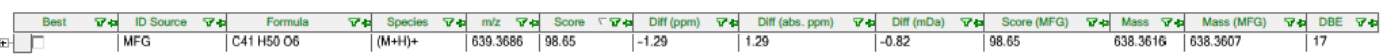

Fig. S6 ESI/HRMS spectrum of 2 


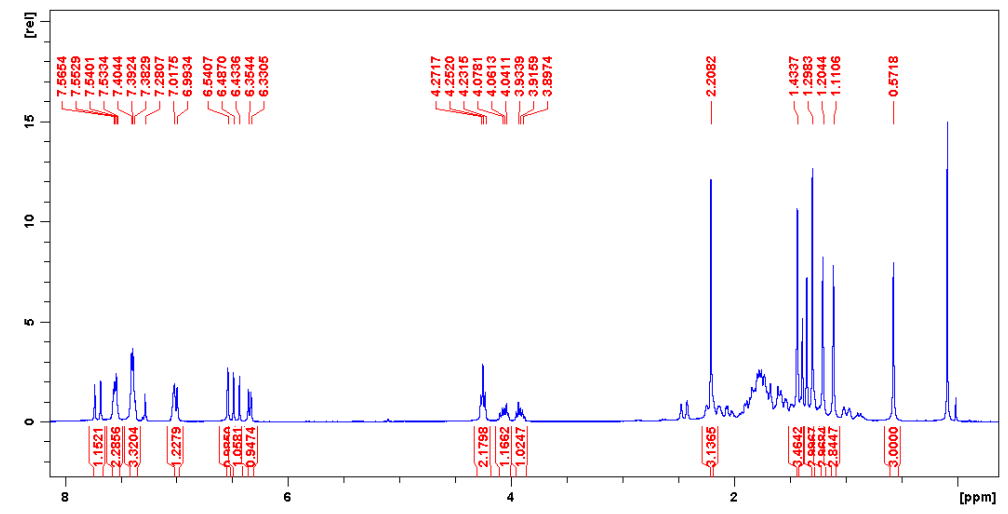

Fig. $\mathrm{S} 7{ }^{1} \mathrm{H}$ NMR spectrum of $\mathbf{3}\left(300 \mathrm{MHz}\right.$ in $\left.\mathrm{CDCl}_{3}\right)$

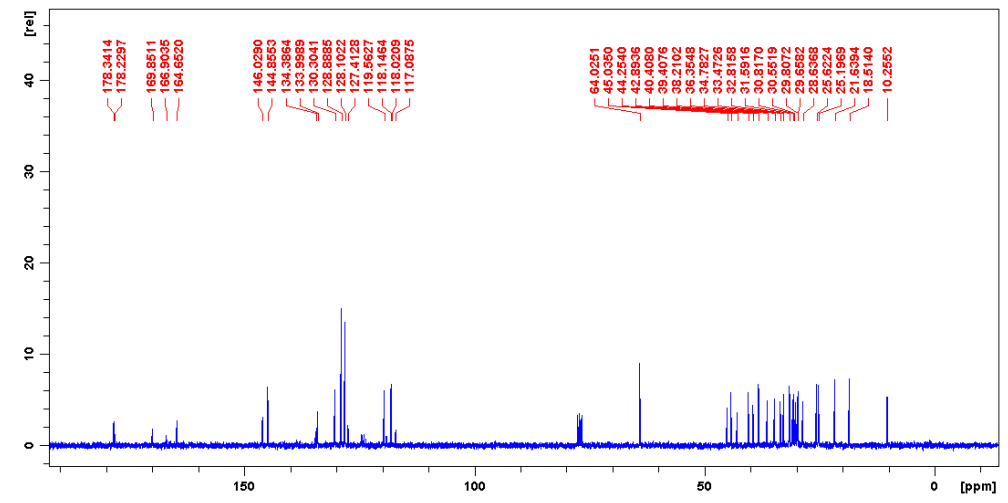

Fig. S8 ${ }^{13} \mathrm{C}$ NMR spectrum of $\mathbf{3}\left(75 \mathrm{MHz}\right.$ in $\left.\mathrm{CDCl}_{3}\right)$

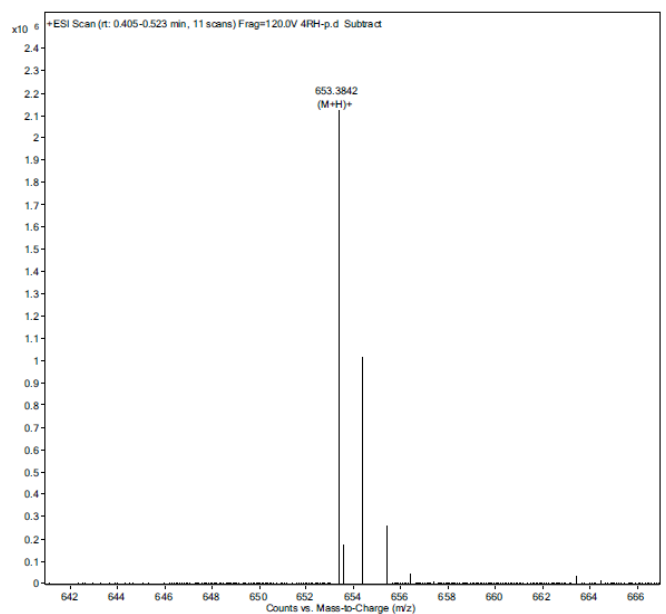

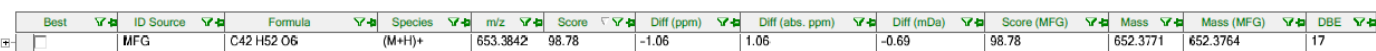

Fig. S9 ESI/HRMS spectrum of $\mathbf{3}$ 


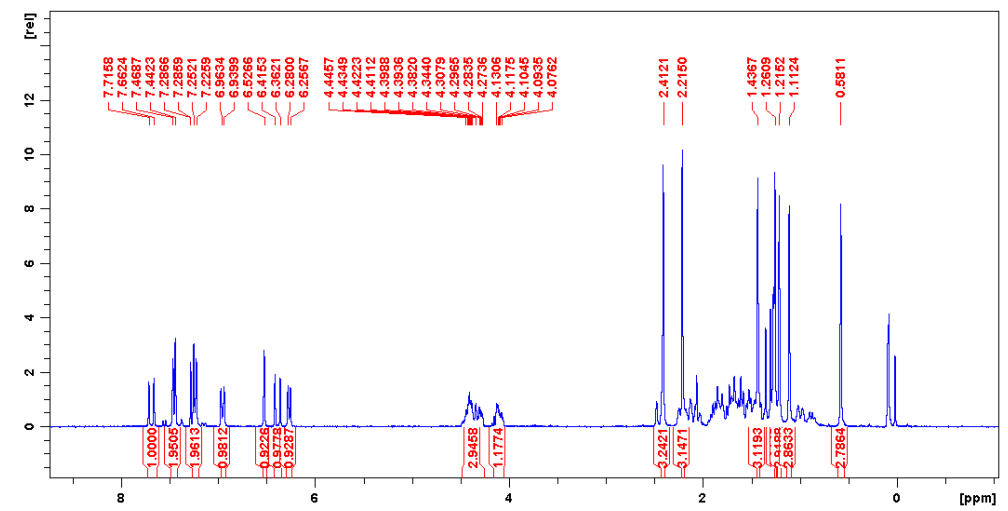

Fig. S10 ${ }^{1} \mathrm{H}$ NMR spectrum of $4\left(300 \mathrm{MHz}\right.$ in $\left.\mathrm{CDCl}_{3}\right)$

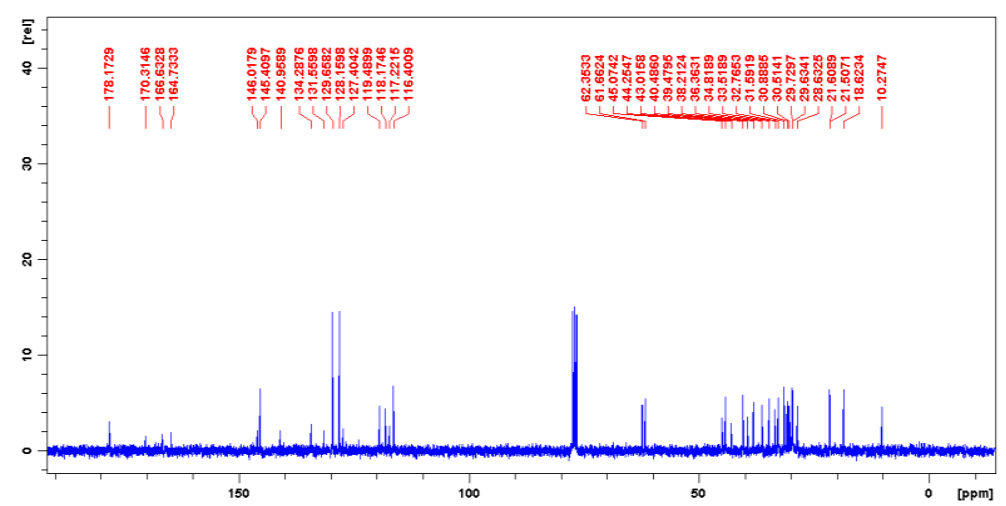

Fig. $\mathrm{S} 11{ }^{13} \mathrm{C}$ NMR spectrum of $4\left(75 \mathrm{MHz}\right.$ in $\left.\mathrm{CDCl}_{3}\right)$
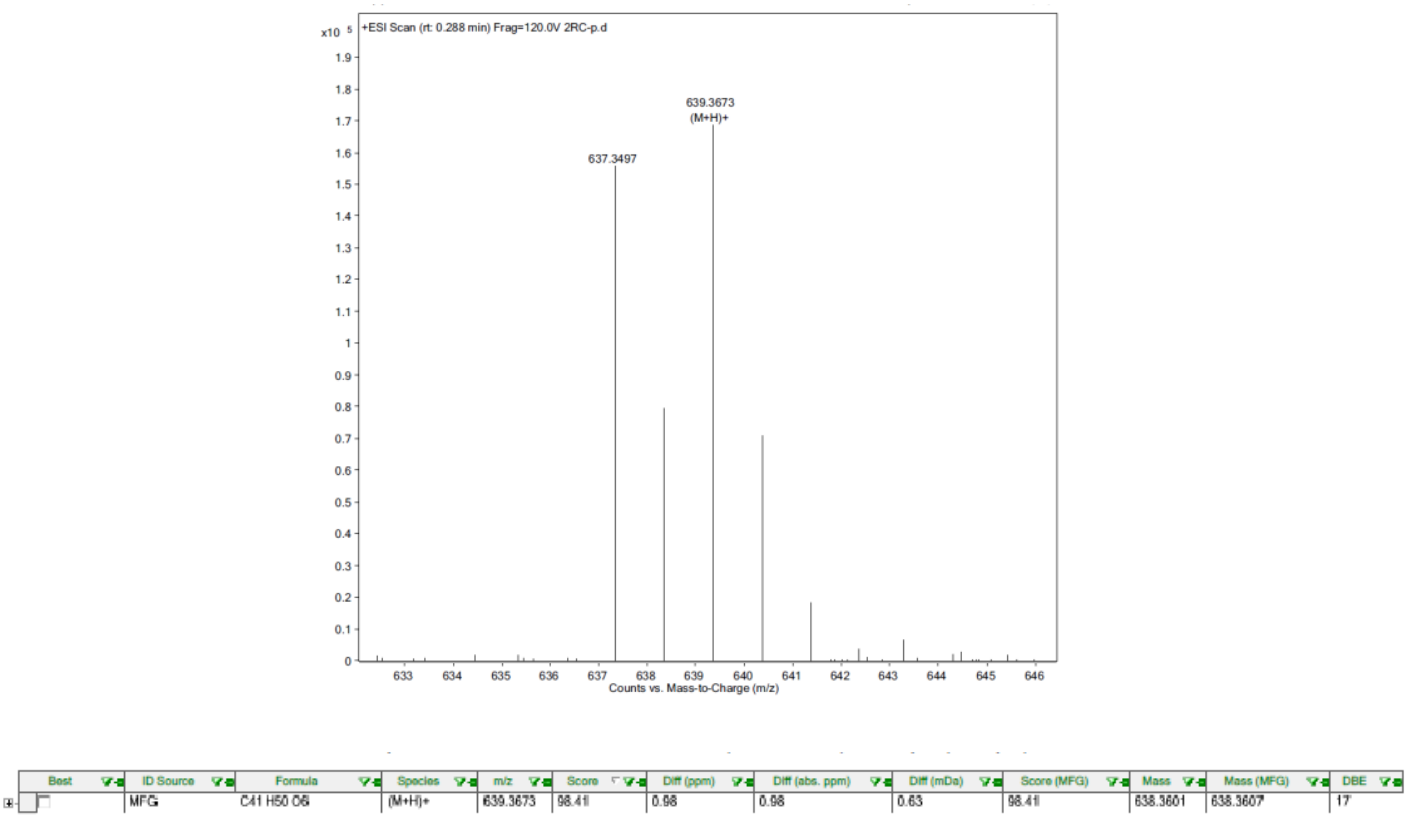

Fig. S12 ESI/HRMS spectrum of 4 


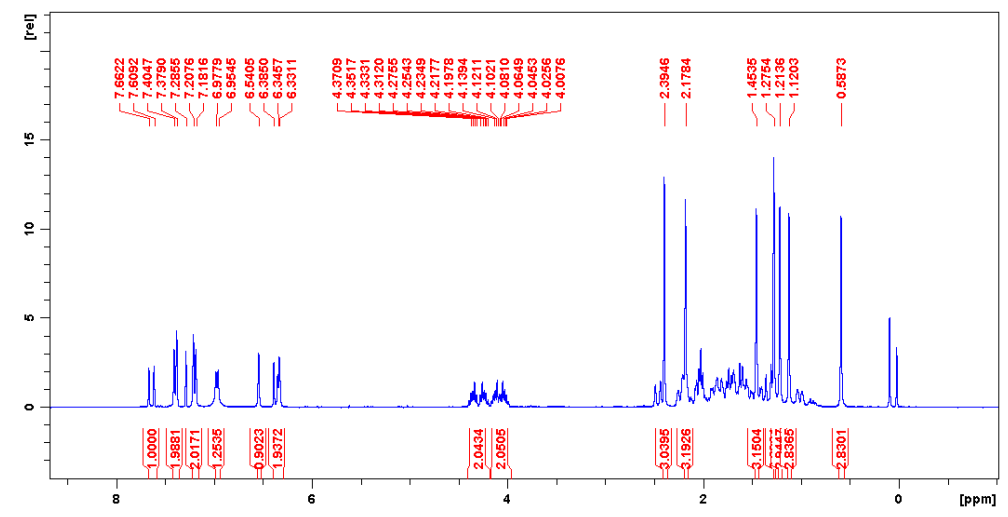

Fig. S13 ${ }^{1} \mathrm{H}$ NMR spectrum of $5\left(300 \mathrm{MHz}\right.$ in $\left.\mathrm{CDCl}_{3}\right)$

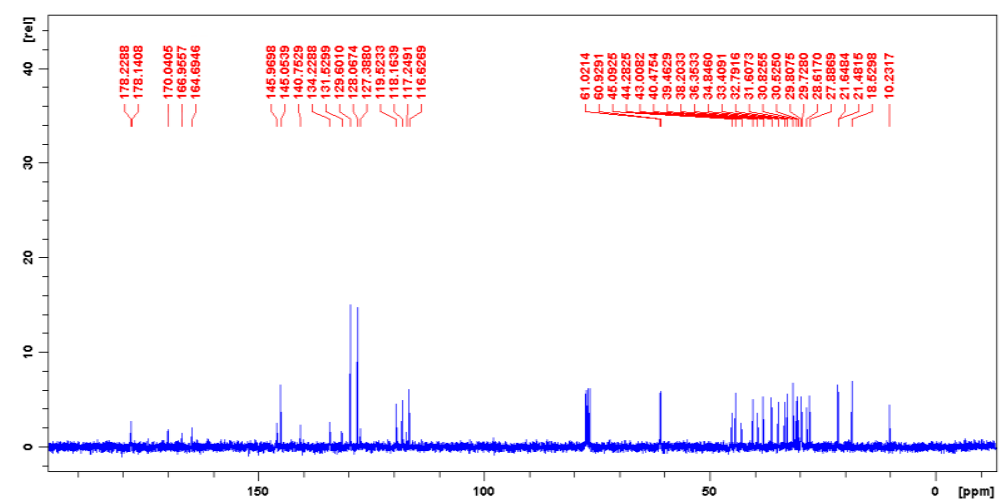

Fig. $\mathrm{S} 14{ }^{13} \mathrm{C}$ NMR spectrum of $5\left(75 \mathrm{MHz}\right.$ in $\left.\mathrm{CDCl}_{3}\right)$

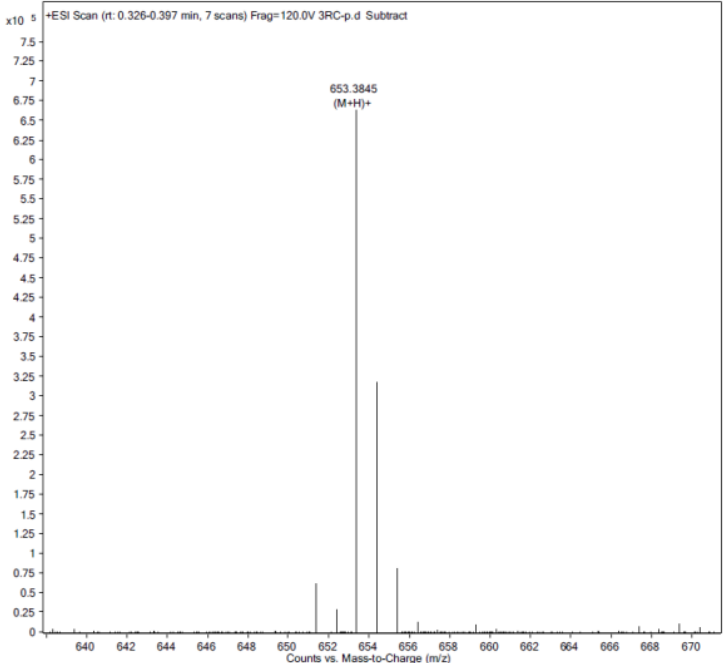

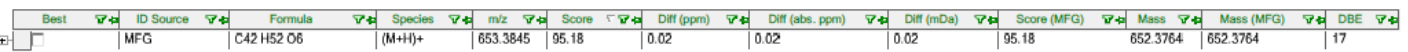

Fig. S15 ESI/HREMS spectrum of 5 


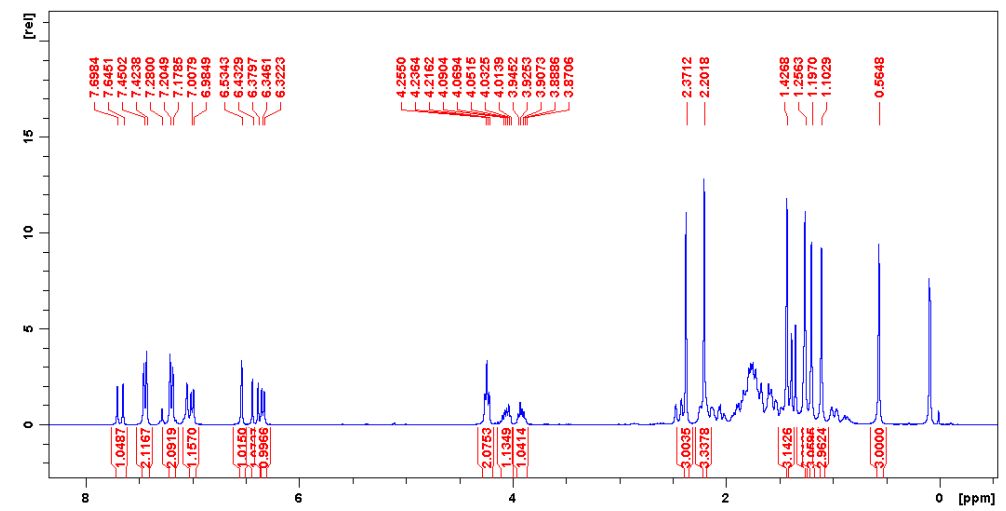

Fig. $\mathrm{S} 16{ }^{1} \mathrm{H}$ NMR spectrum of $6\left(300 \mathrm{MHz}\right.$ in $\left.\mathrm{CDCl}_{3}\right)$

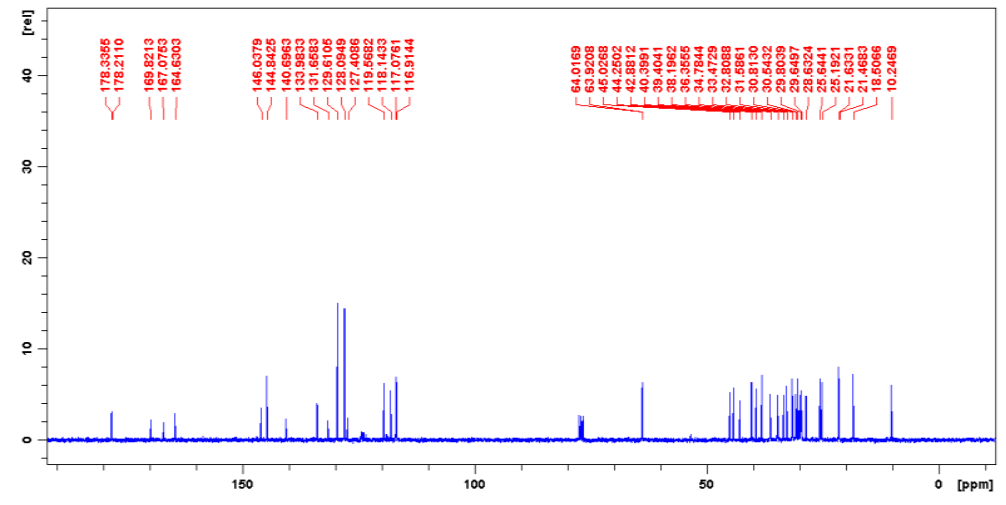

Fig. $\mathrm{S} 17{ }^{13} \mathrm{C}$ NMR spectrum of $6\left(75 \mathrm{MHz}\right.$ in $\left.\mathrm{CDCl}_{3}\right)$
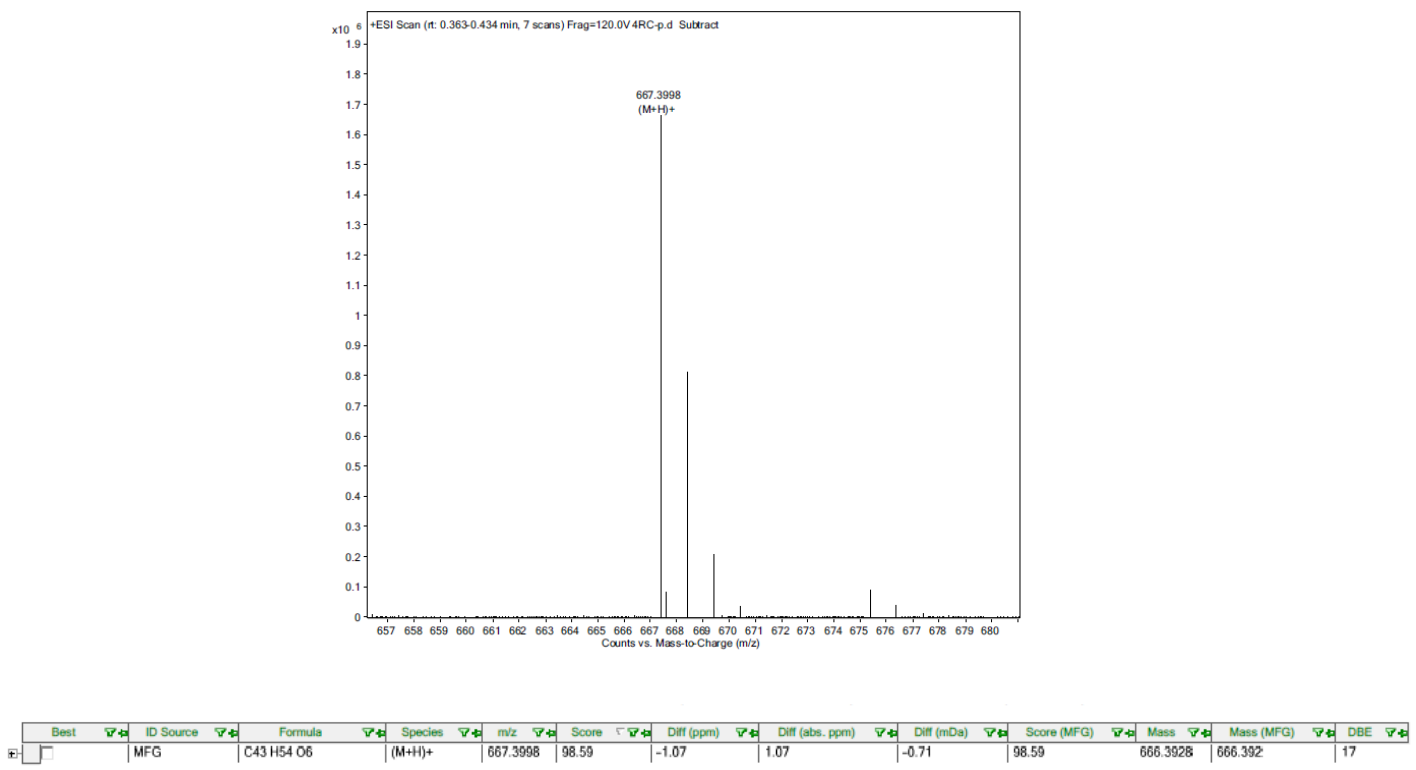

Fig. S18 ESI/HREMS spectrum of 6 


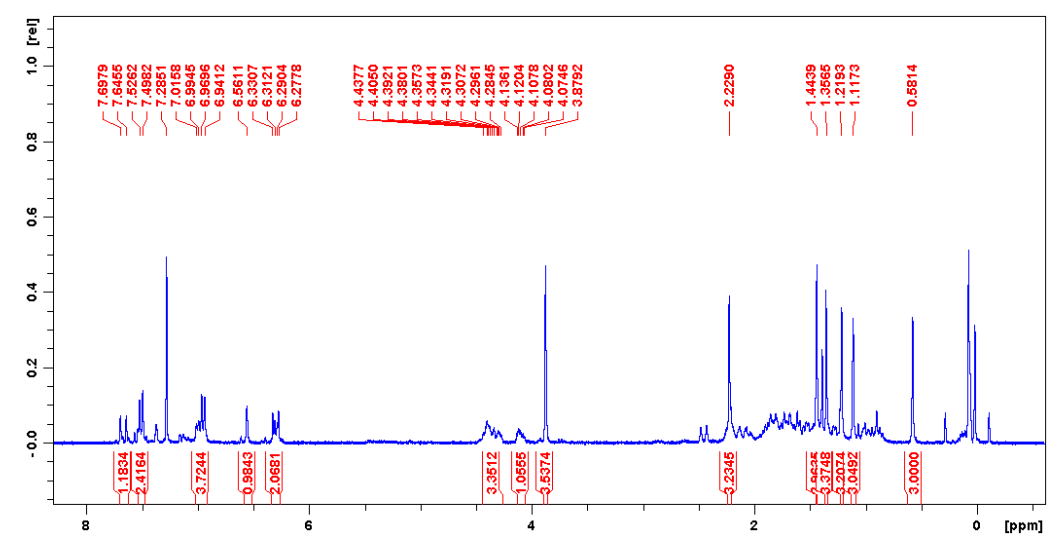

Fig. S19 ${ }^{1} \mathrm{H}$ NMR spectrum of $7\left(300 \mathrm{MHz}\right.$ in $\left.\mathrm{CDCl}_{3}\right)$

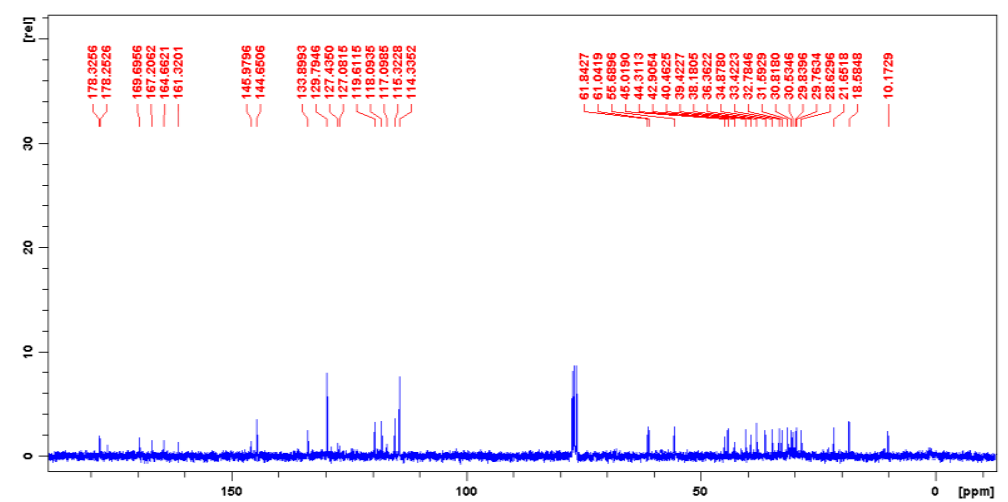

Fig. S20 ${ }^{13} \mathrm{C}$ NMR spectrum of $7\left(75 \mathrm{MHz}\right.$ in $\left.\mathrm{CDCl}_{3}\right)$
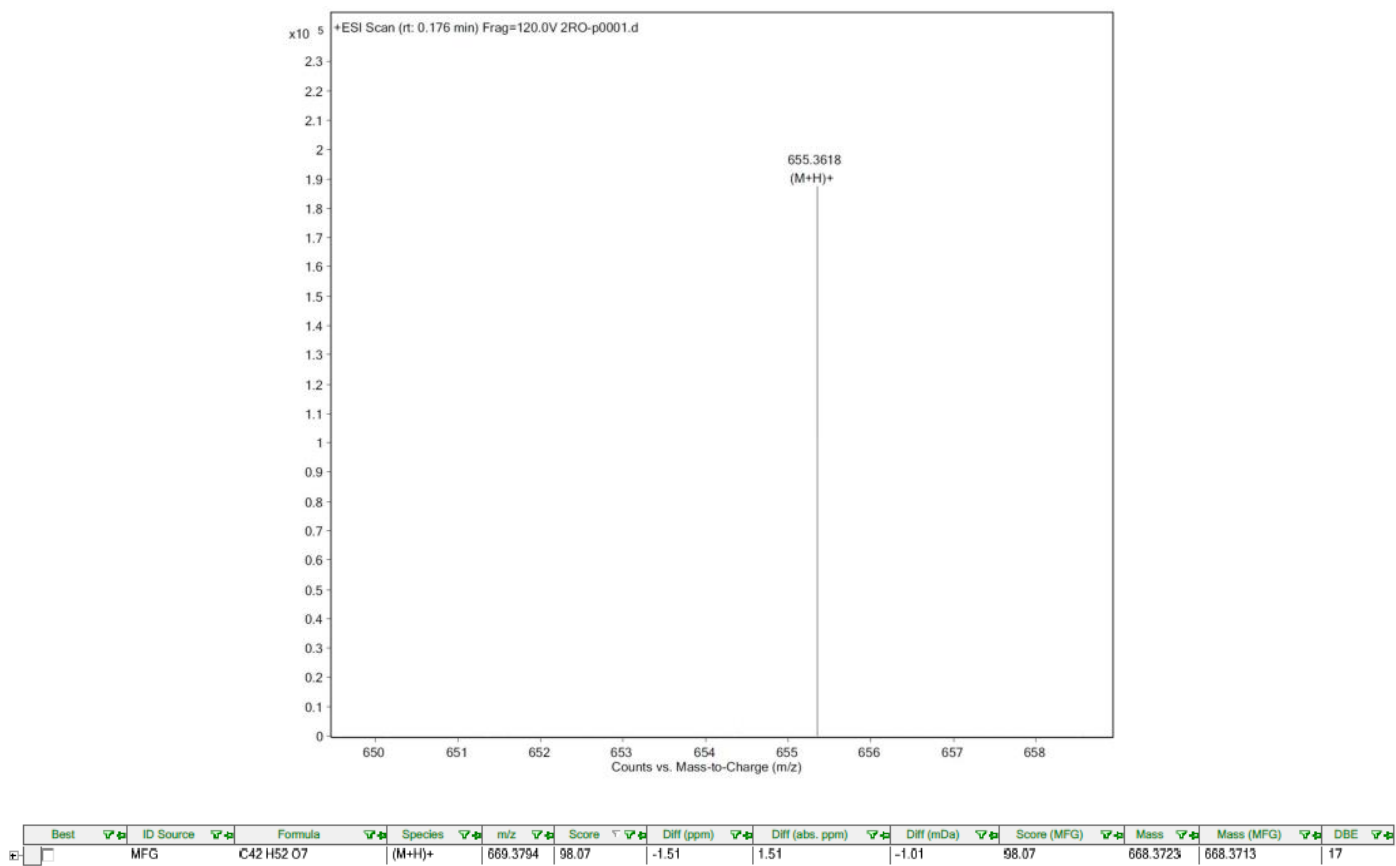

Fig. S21 ESI/HRMS spectrum of 7 


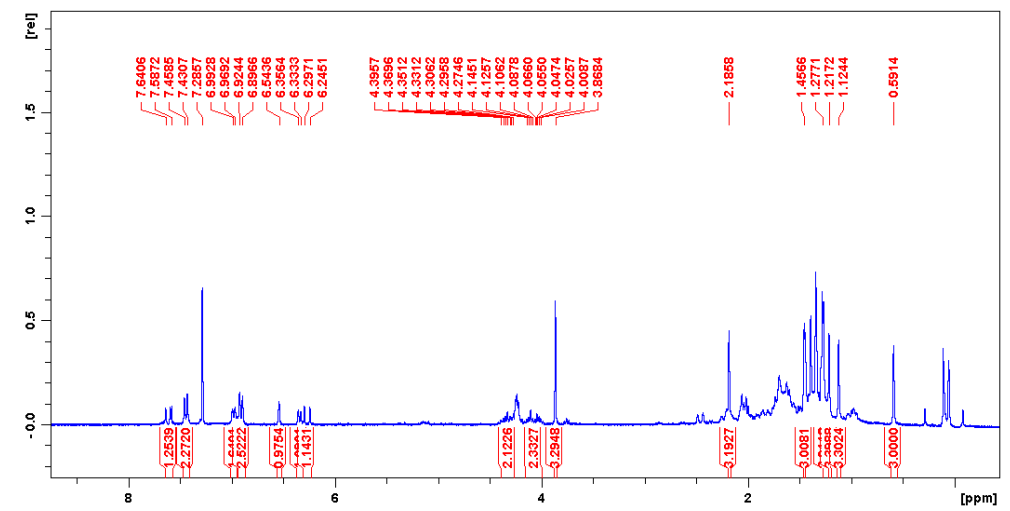

Fig. S22 ${ }^{1} \mathrm{H}$ NMR spectrum of $8\left(300 \mathrm{MHz}\right.$ in $\left.\mathrm{CDCl}_{3}\right)$

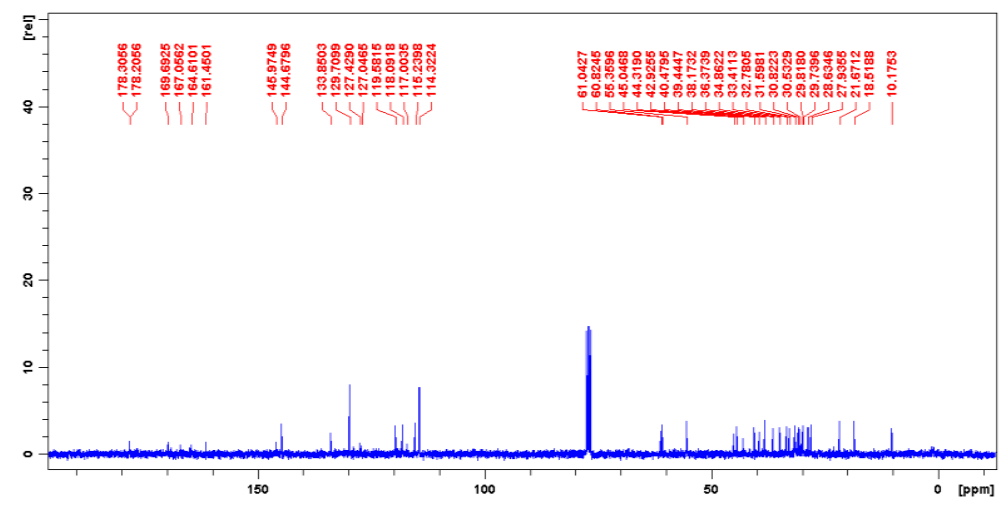

Fig. S23 ${ }^{13} \mathrm{C}$ NMR spectrum of $8\left(75 \mathrm{MHz}\right.$ in $\left.\mathrm{CDCl}_{3}\right)$
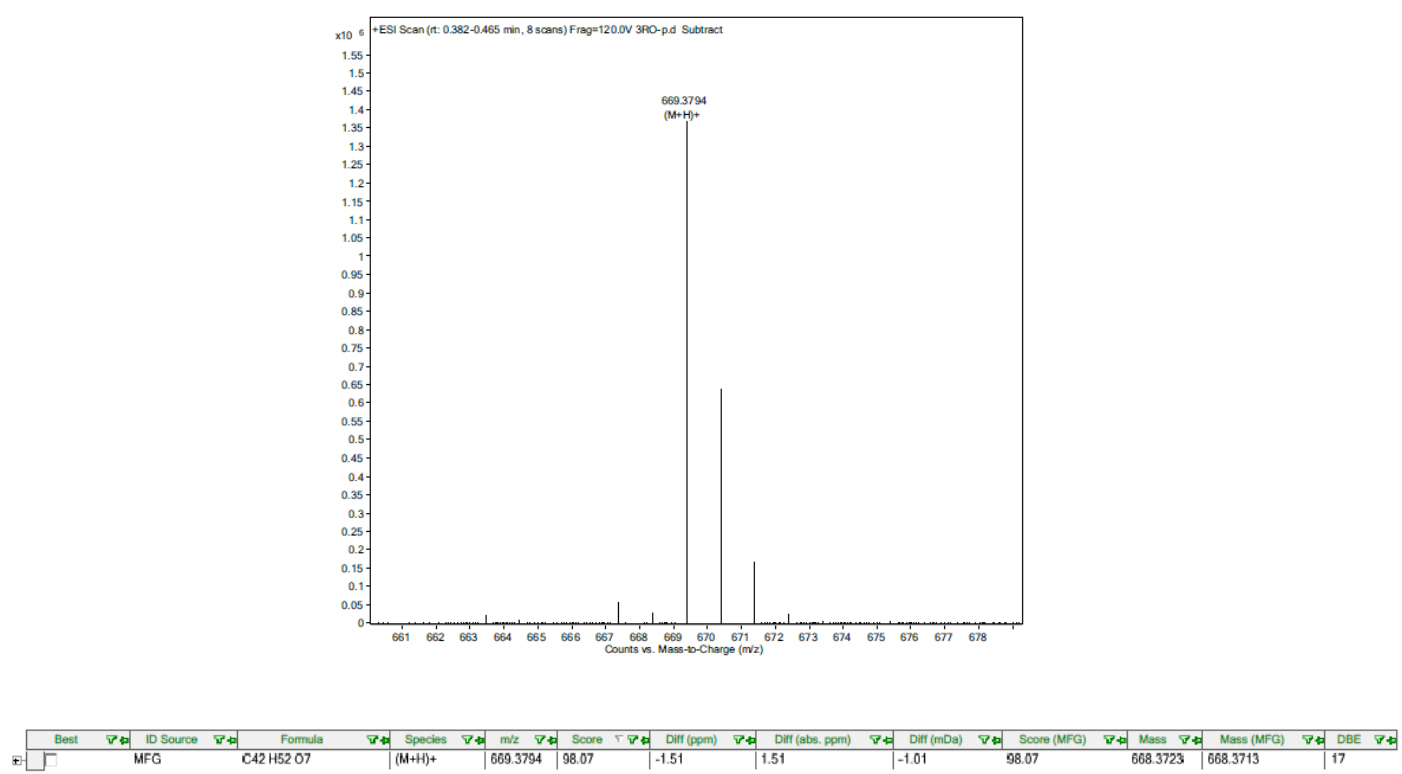

Fig. S24 ESI/HRMS spectrum of 8 


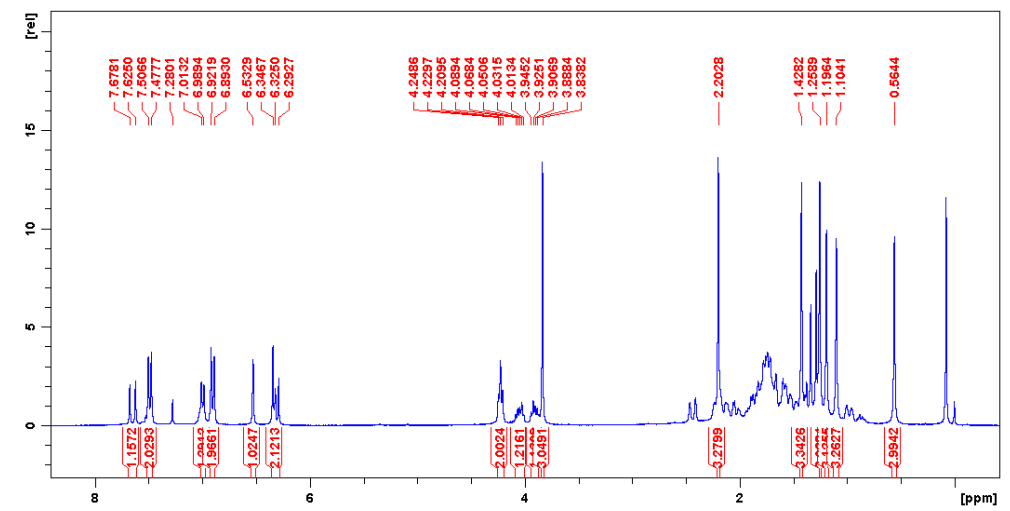

Fig. S25 ${ }^{1} \mathrm{H}$ NMR spectrum of $9\left(300 \mathrm{MHz}\right.$ in $\left.\mathrm{CDCl}_{3}\right)$

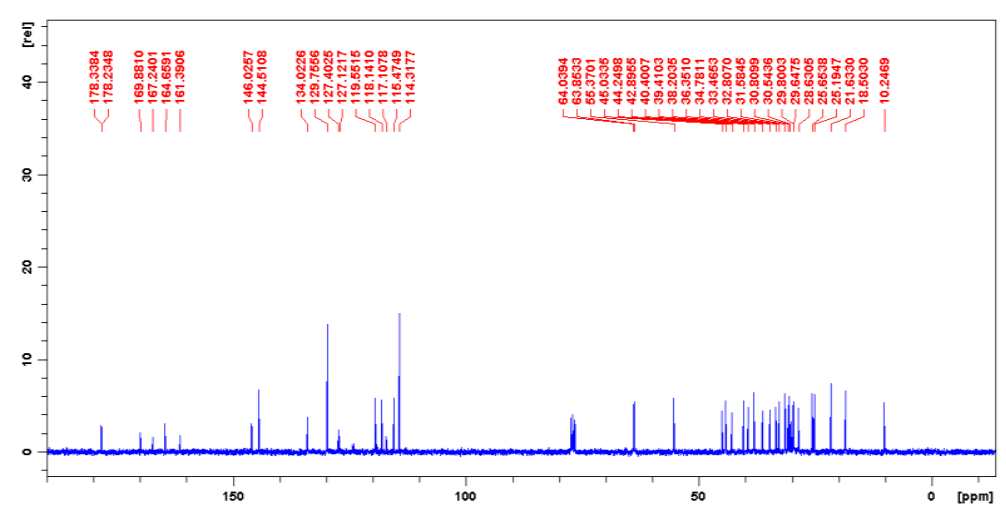

Fig. S26 ${ }^{13} \mathrm{C}$ NMR spectrum of 9 (75 MHz in DMSO- $d_{6}$ )
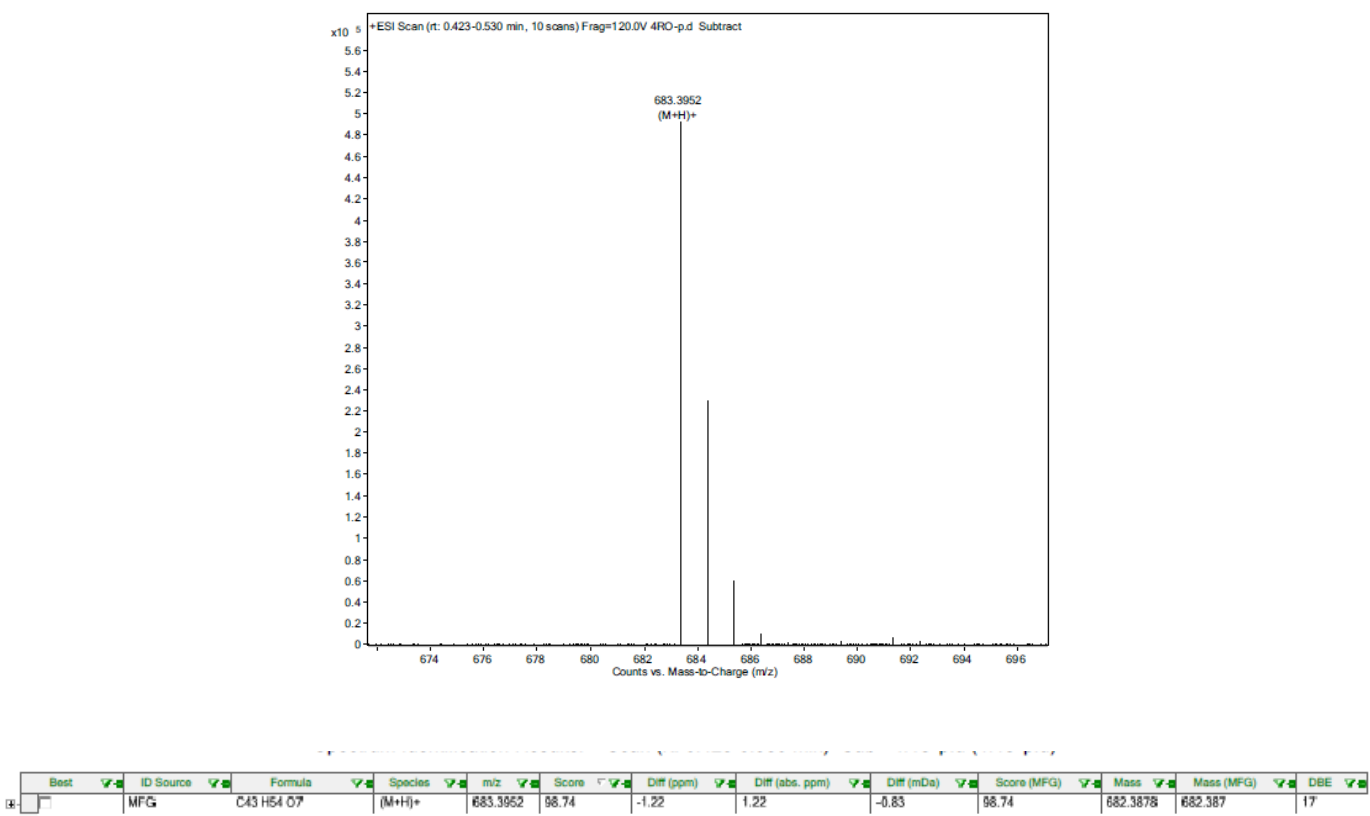

Fig. S27 ESI/HRMS spectrum of 9 


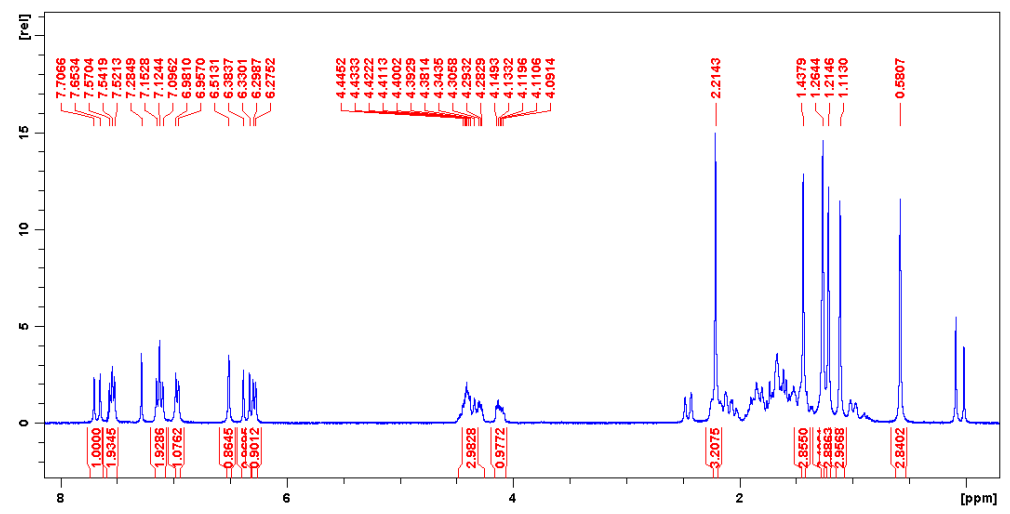

Fig. S28 ${ }^{1} \mathrm{H}$ NMR spectrum of $\mathbf{1 0}\left(300 \mathrm{MHz}\right.$ in $\left.\mathrm{CDCl}_{3}\right)$

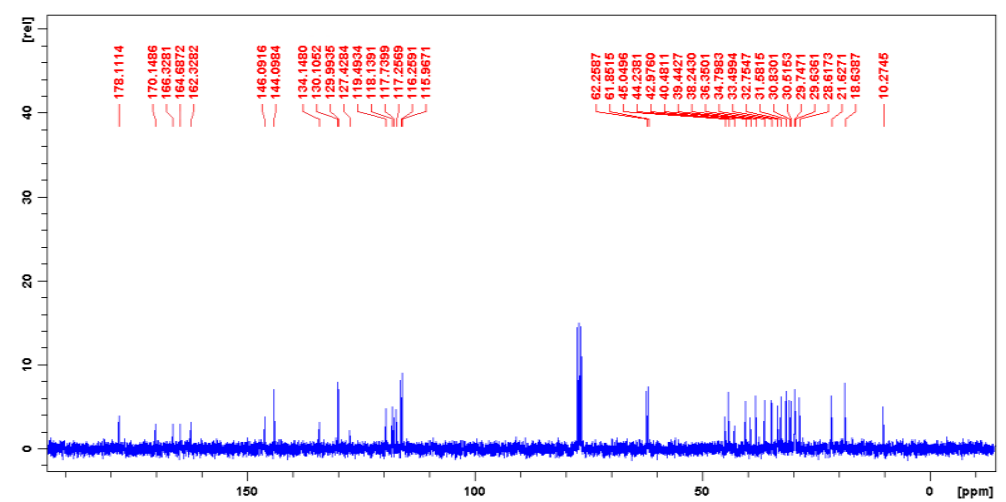

Fig. S29 ${ }^{13} \mathrm{C}$ NMR spectrum of $\mathbf{1 0}\left(75 \mathrm{MHz}\right.$ in $\left.\mathrm{CDCl}_{3}\right)$
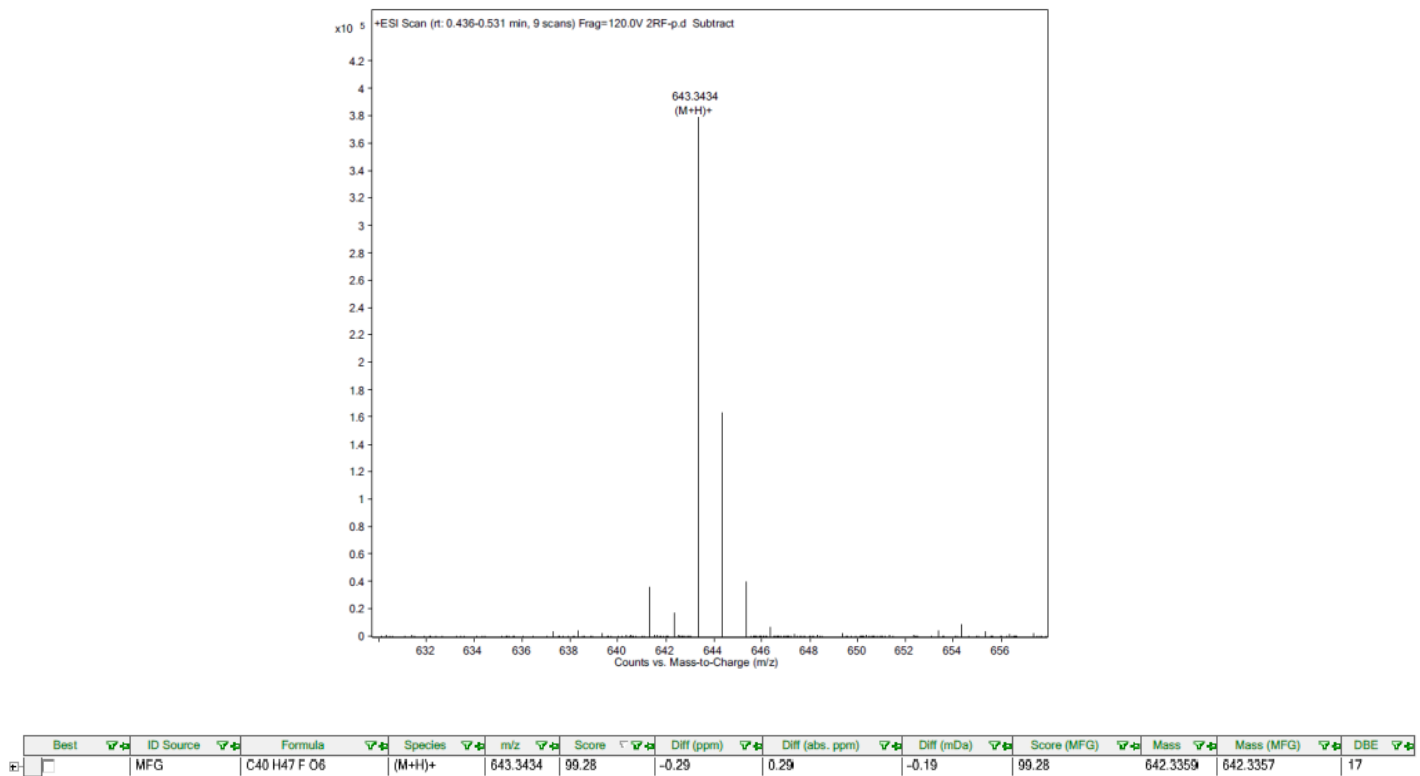

Fig. S30 ESI/HRMS spectrum of $\mathbf{1 0}$ 


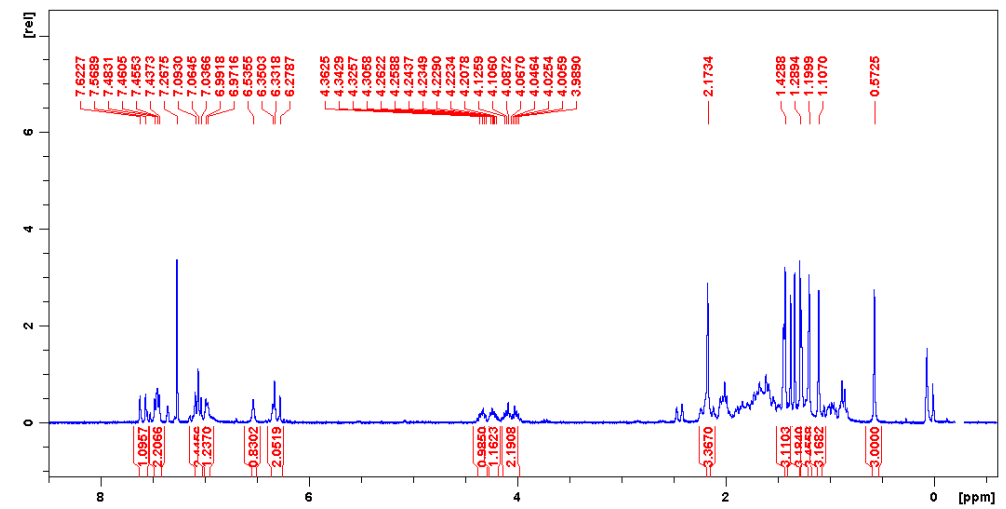

Fig. S31 ${ }^{1} \mathrm{H}$ NMR spectrum of $\mathbf{1 1}\left(300 \mathrm{MHz}\right.$ in $\left.\mathrm{CDCl}_{3}\right)$

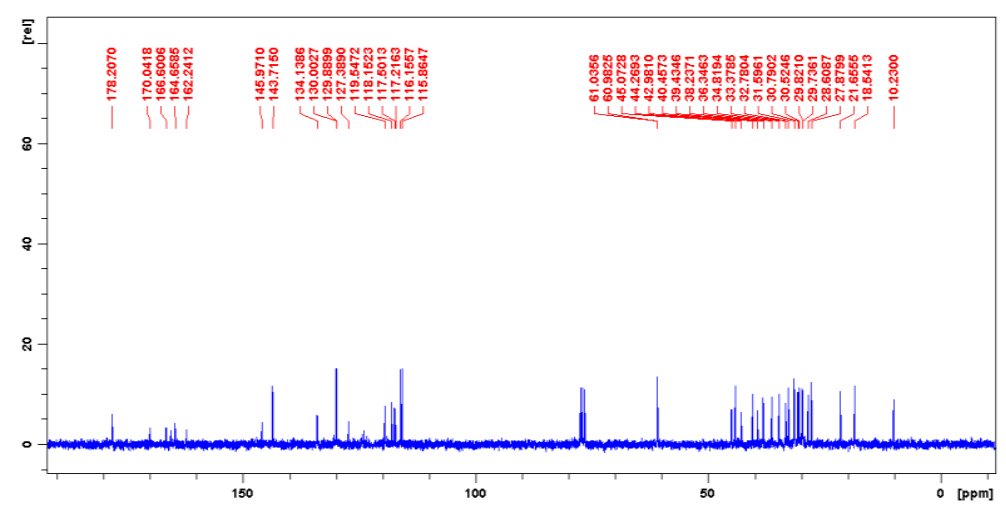

Fig. S32 ${ }^{13} \mathrm{C}$ NMR spectrum of $\mathbf{1 1}\left(75 \mathrm{MHz}\right.$ in $\left.\mathrm{CDCl}_{3}\right)$

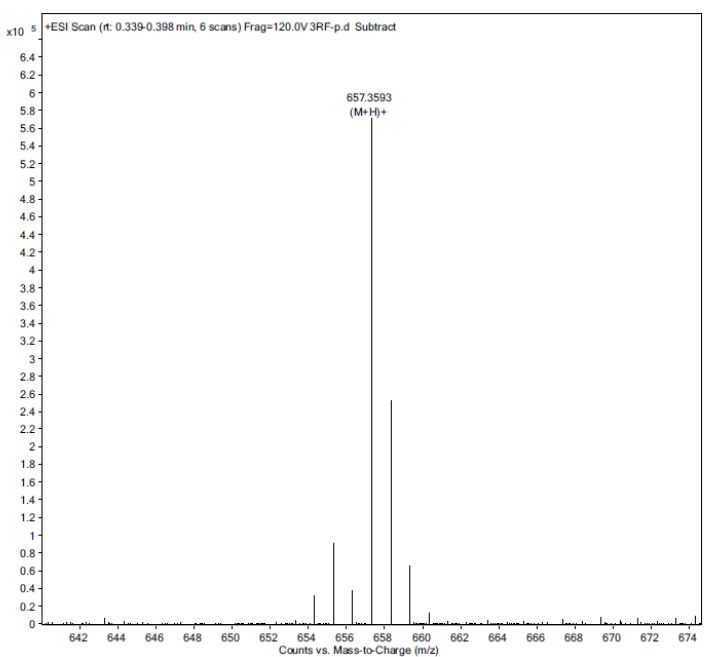

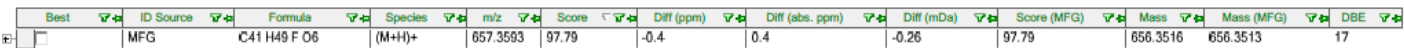

Fig. S33 ESI/HRMS spectrum of $\mathbf{1 1}$ 


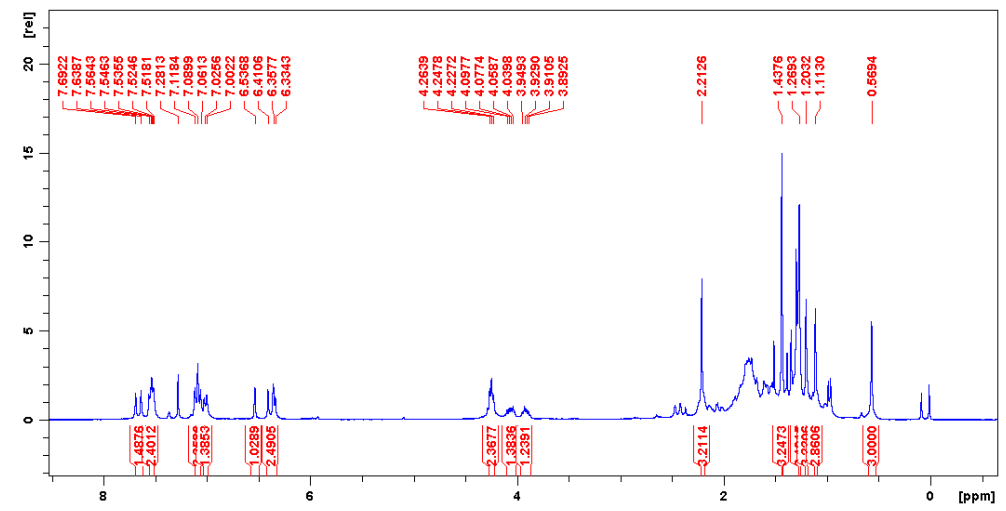

Fig. S34. ${ }^{1} \mathrm{H}$ NMR spectrum of $12\left(300 \mathrm{MHz}\right.$ in $\left.\mathrm{CDCl}_{3}\right)$

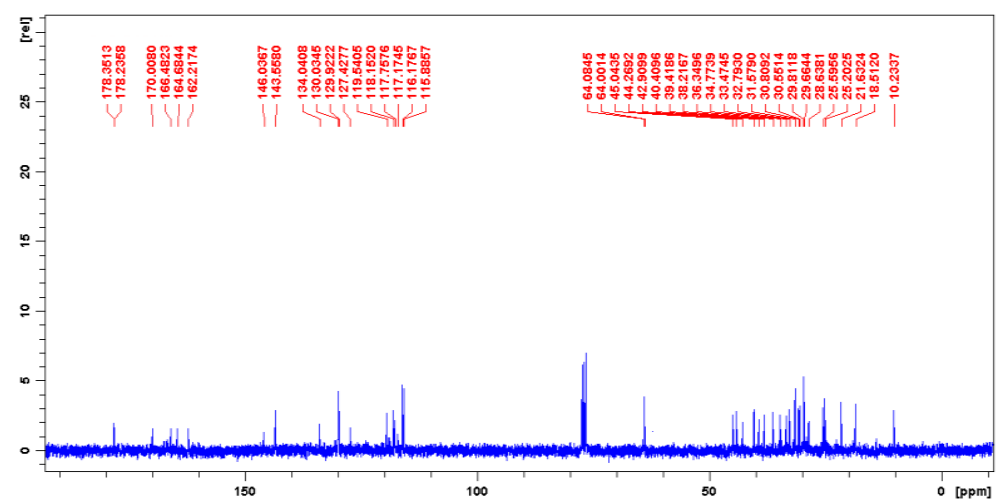

Fig. S35. ${ }^{13} \mathrm{C}$ NMR spectrum of $\mathbf{1 2}\left(75 \mathrm{MHz}\right.$ in $\left.\mathrm{CDCl}_{3}\right)$
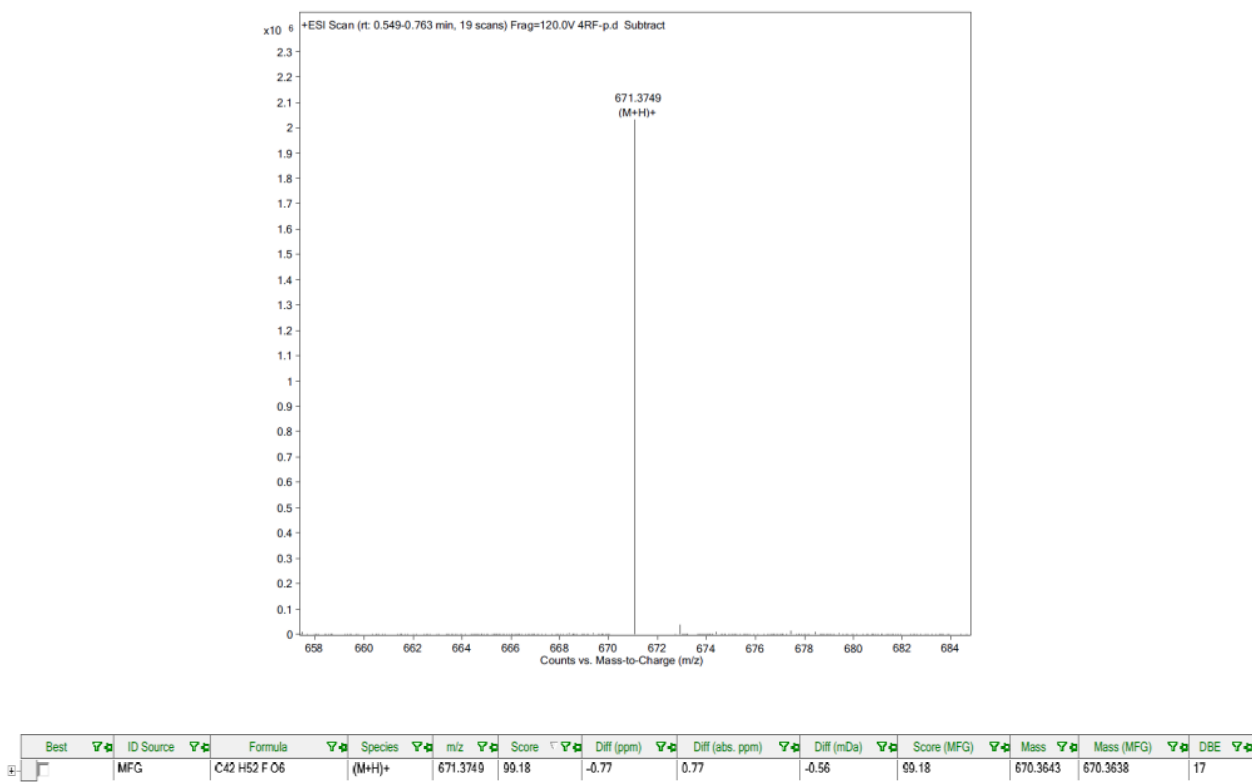

Fig. S36 ESI/HRMS spectrum of $\mathbf{1 2}$ 


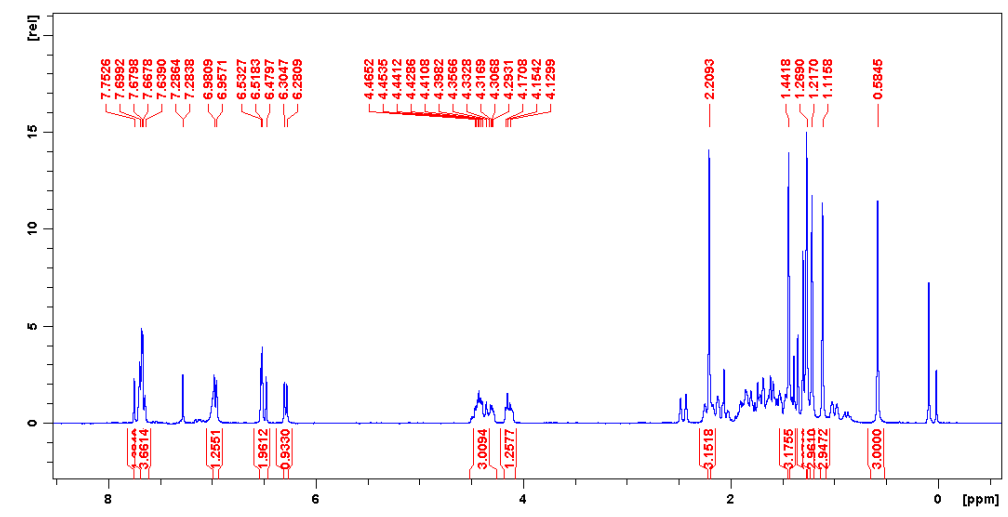

Fig. S37 ${ }^{1} \mathrm{H}$ NMR spectrum of $13\left(300 \mathrm{MHz}\right.$ in $\left.\mathrm{CDCl}_{3}\right)$

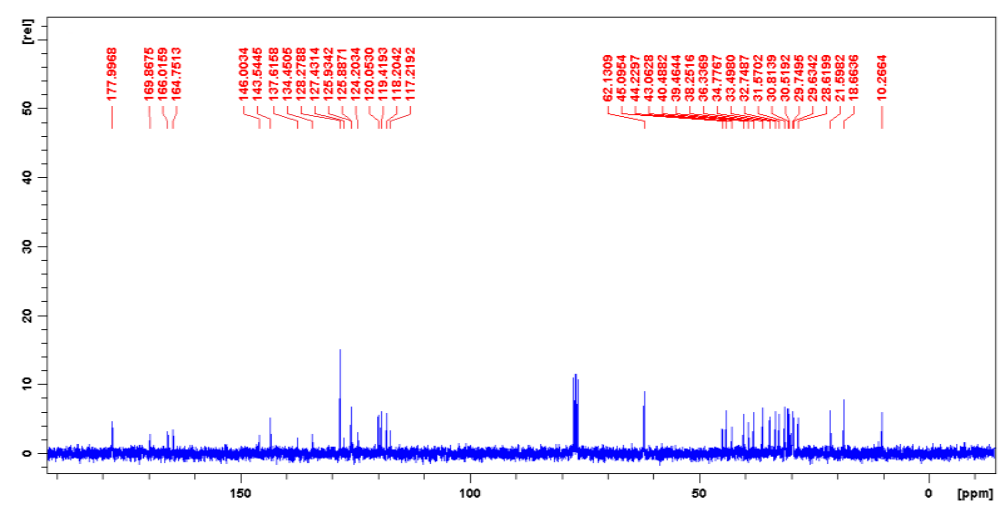

Fig. S38 ${ }^{13} \mathrm{C}$ NMR spectrum of $\mathbf{1 3}\left(75 \mathrm{MHz}\right.$ in $\left.\mathrm{CDCl}_{3}\right)$
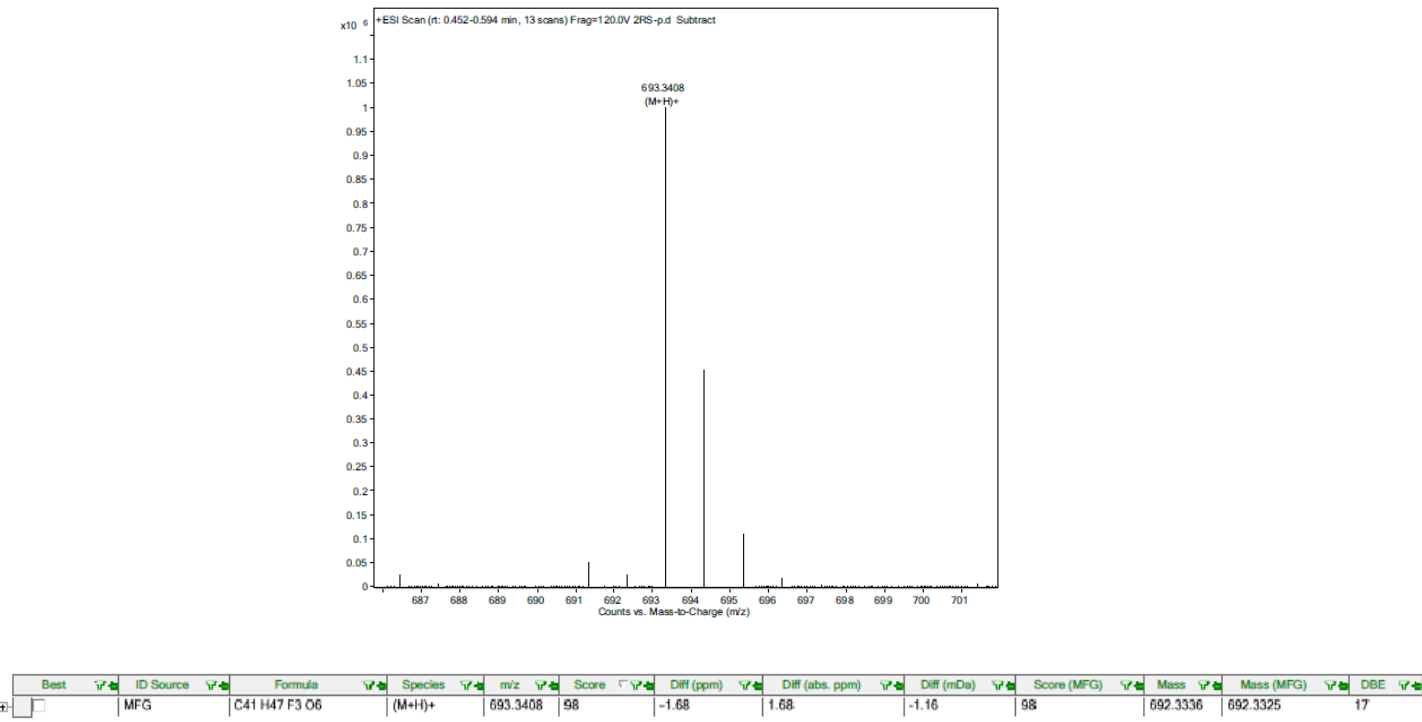

Fig. S39 ESI/HRMS spectrum of $\mathbf{1 3}$ 


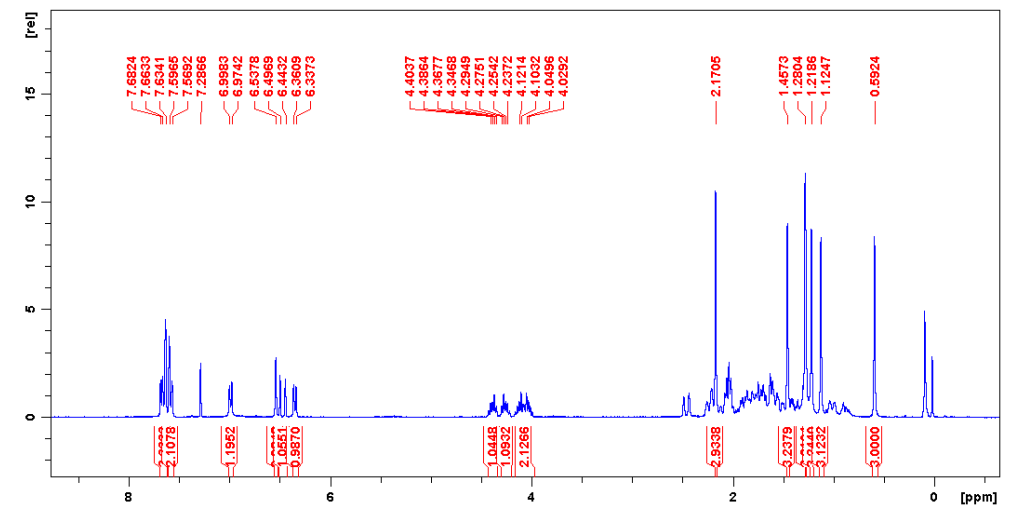

Fig. S40 ${ }^{1} \mathrm{H}$ NMR spectrum of $\mathbf{1 4}\left(300 \mathrm{MHz}\right.$ in $\left.\mathrm{CDCl}_{3}\right)$

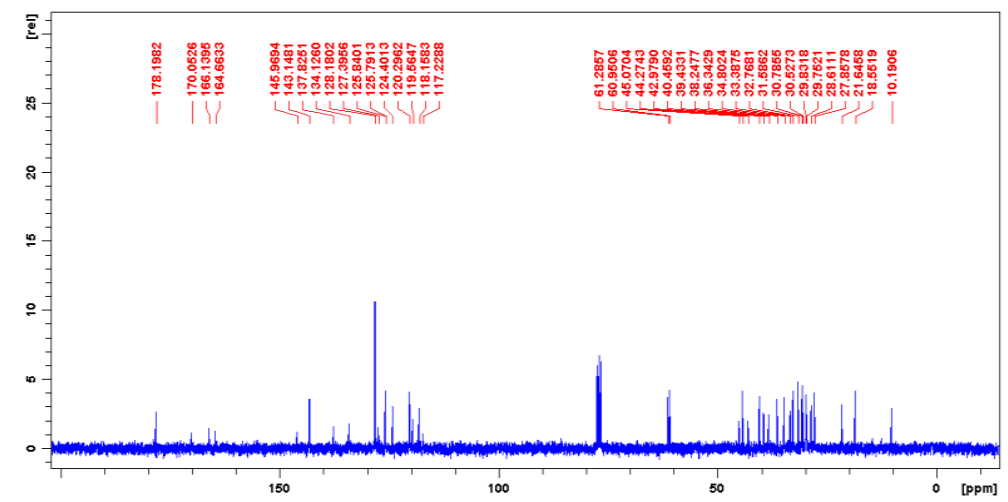

Fig. S4 ${ }^{13} \mathrm{C}$ NMR spectrum of $\mathbf{1 4}\left(75 \mathrm{MHz}\right.$ in $\left.\mathrm{CDCl}_{3}\right)$
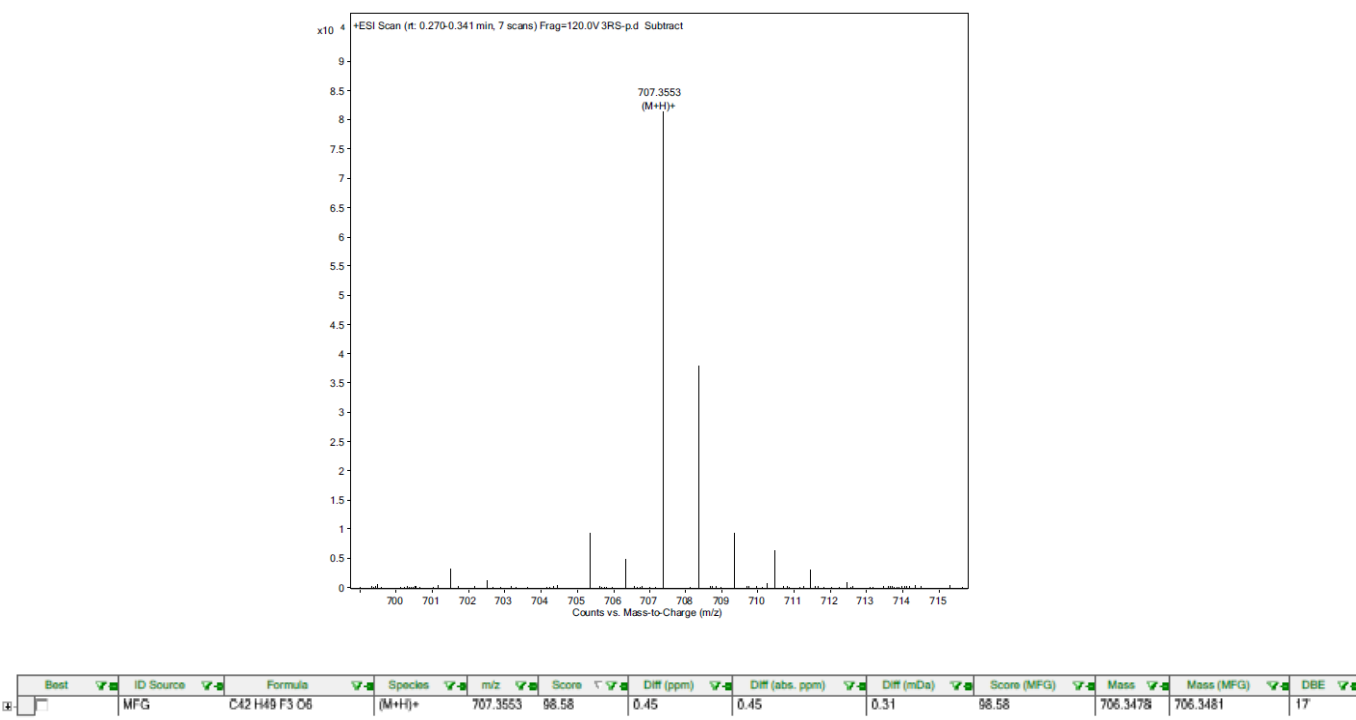

Fig. S42 ESI/HRMS spectrum of 14 


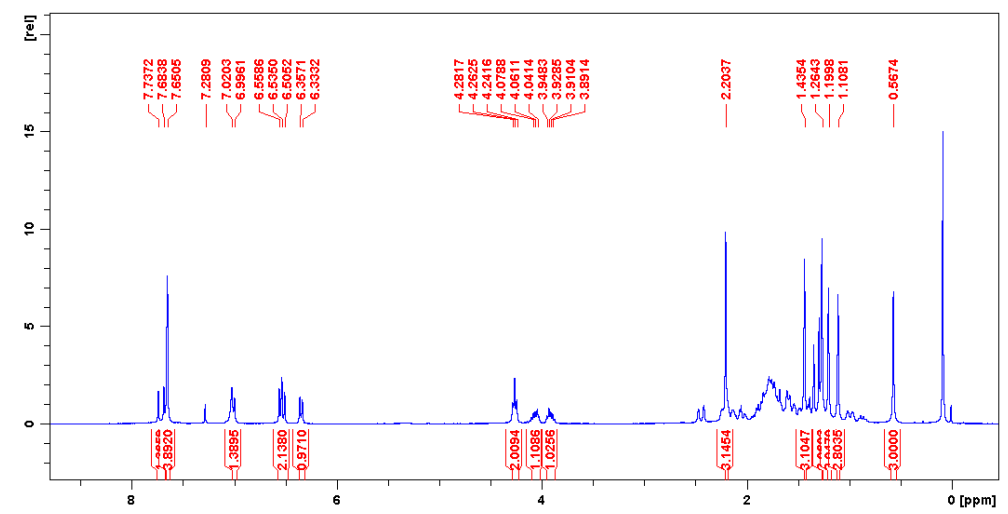

Fig. S43 ${ }^{1} \mathrm{H}$ NMR spectrum of $15\left(300 \mathrm{MHz}\right.$ in $\left.\mathrm{CDCl}_{3}\right)$

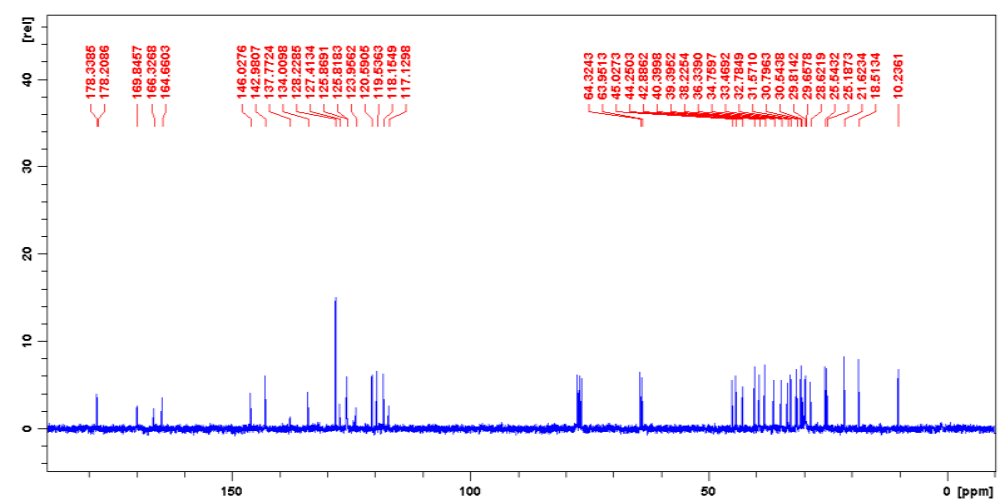

Fig. S44 ${ }^{13} \mathrm{C}$ NMR spectrum of $15\left(75 \mathrm{MHz}\right.$ in $\left.\mathrm{CDCl}_{3}\right)$

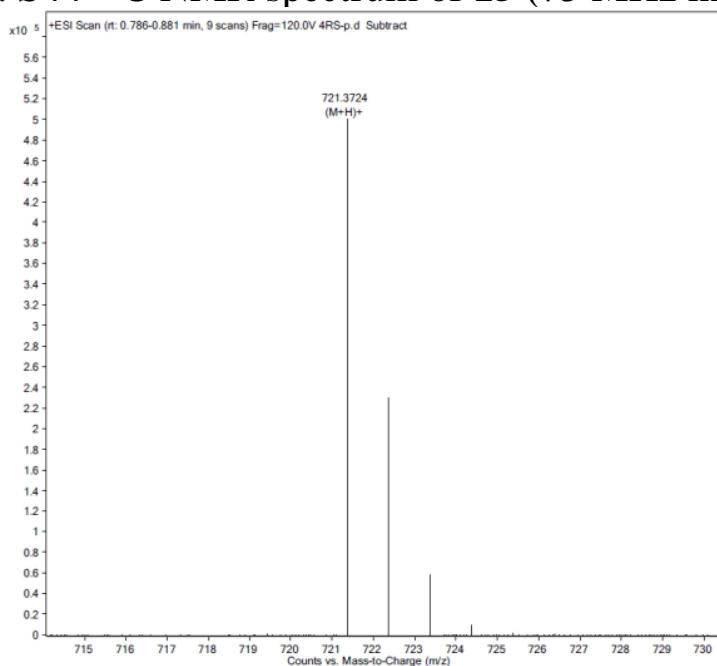

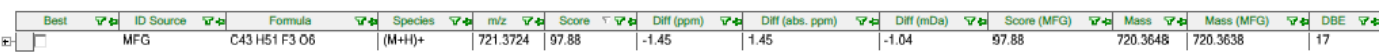

Fig. S45 ESI/HRMS spectrum of $\mathbf{1 5}$ 


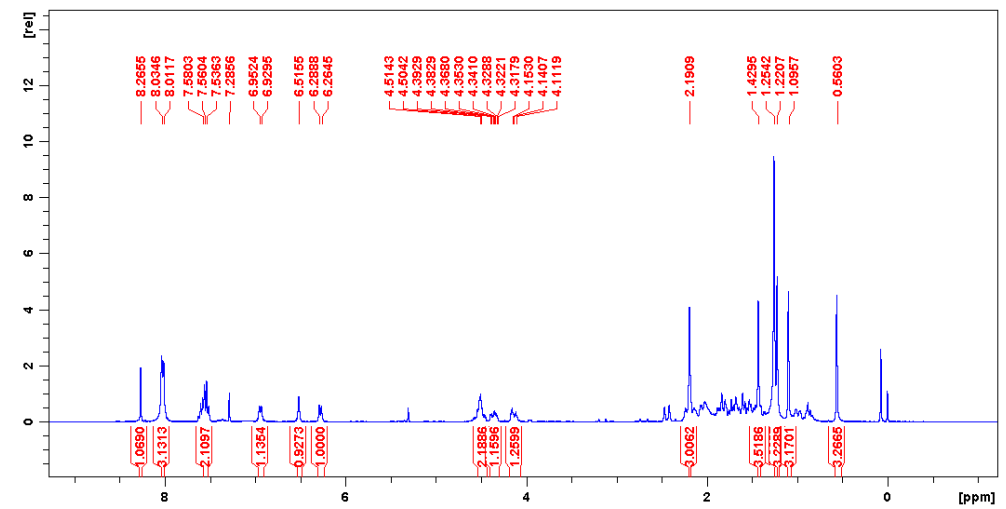

Fig. $\mathrm{S} 46{ }^{1} \mathrm{H}$ NMR spectrum of $16\left(300 \mathrm{MHz}\right.$ in $\left.\mathrm{CDCl}_{3}\right)$

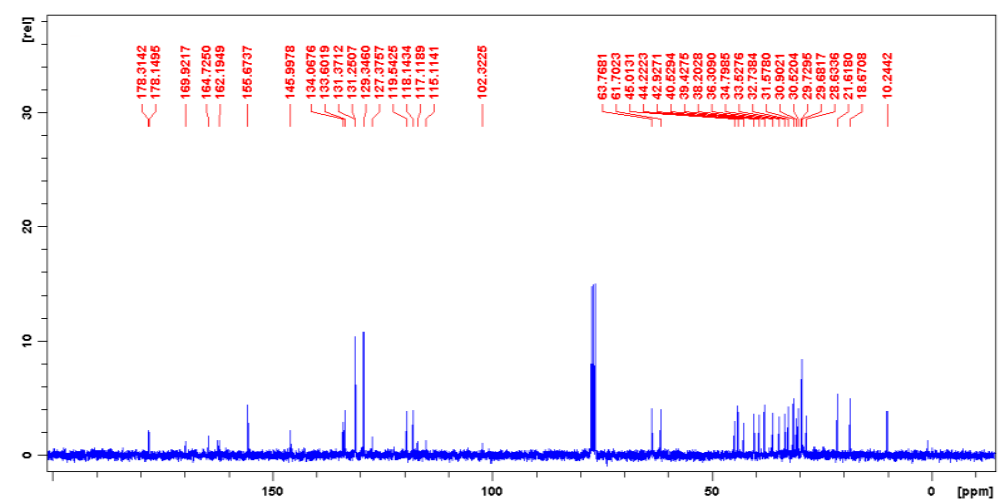

Fig. $\mathrm{S} 47{ }^{13} \mathrm{C}$ NMR spectrum of $\mathbf{1 6}\left(75 \mathrm{MHz}\right.$ in $\left.\mathrm{CDCl}_{3}\right)$
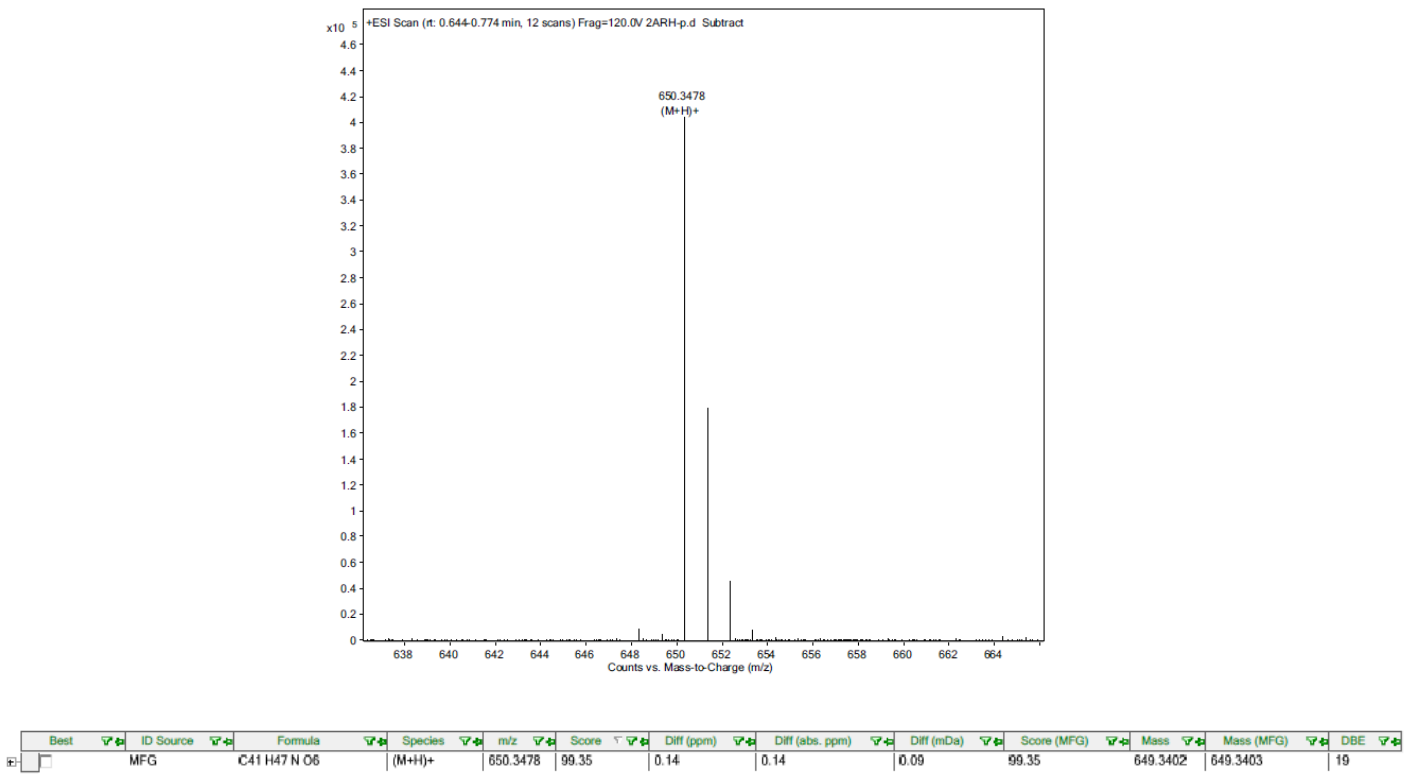

Fig. S48 ESI/HRMS spectrum of $\mathbf{1 6}$ 


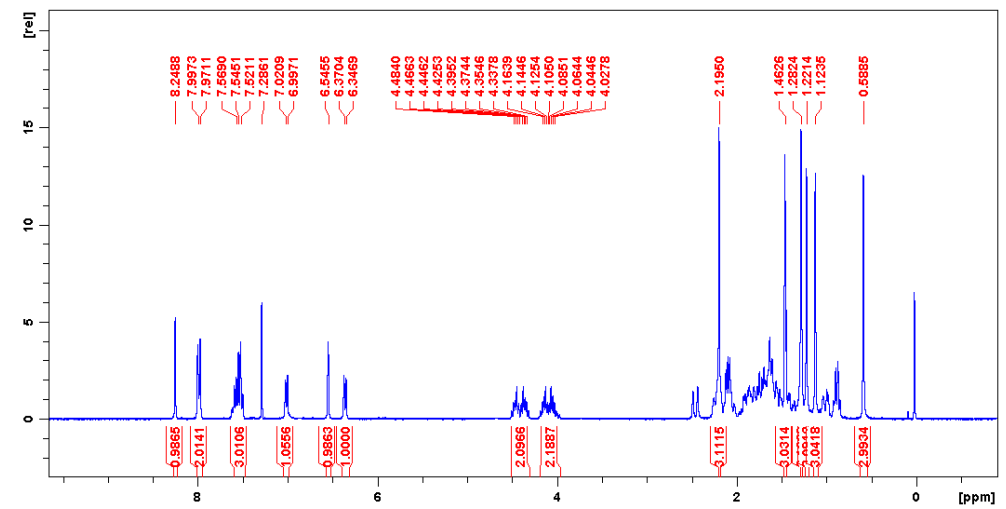

Fig. S49 ${ }^{1} \mathrm{H}$ NMR spectrum of $17\left(300 \mathrm{MHz}\right.$ in $\left.\mathrm{CDCl}_{3}\right)$

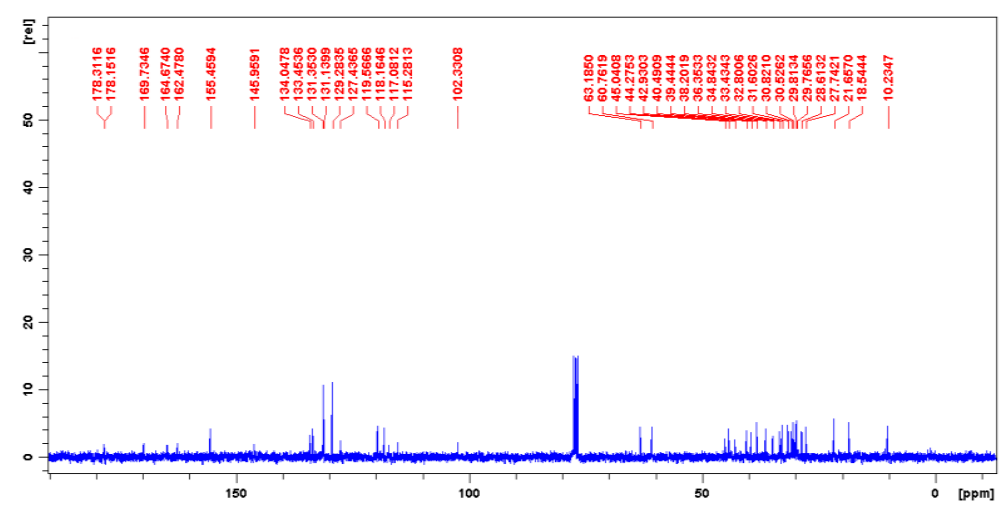

Fig. S50 ${ }^{13} \mathrm{C}$ NMR spectrum of $\mathbf{1 7}\left(75 \mathrm{MHz}\right.$ in $\left.\mathrm{CDCl}_{3}\right)$

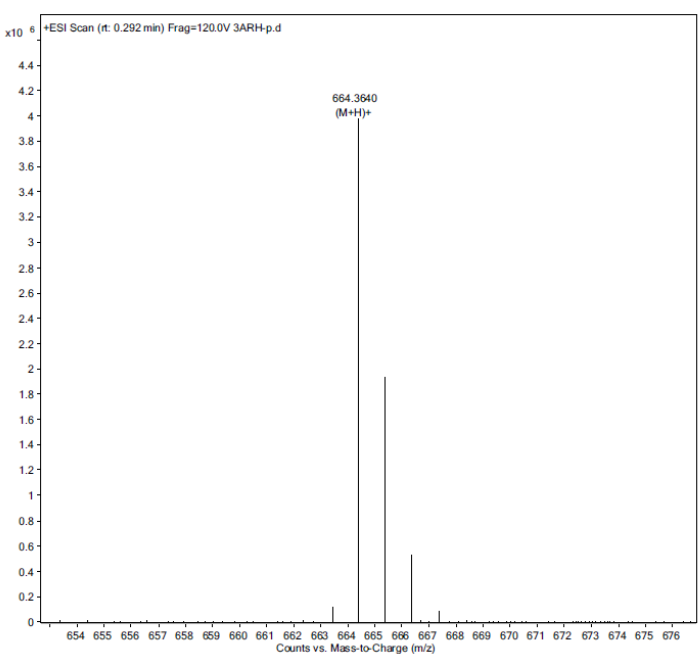

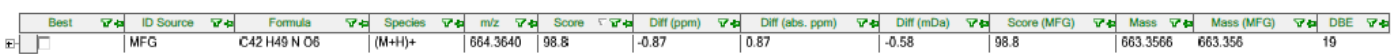

Fig. S51 ESI/HRMS spectrum of 17 


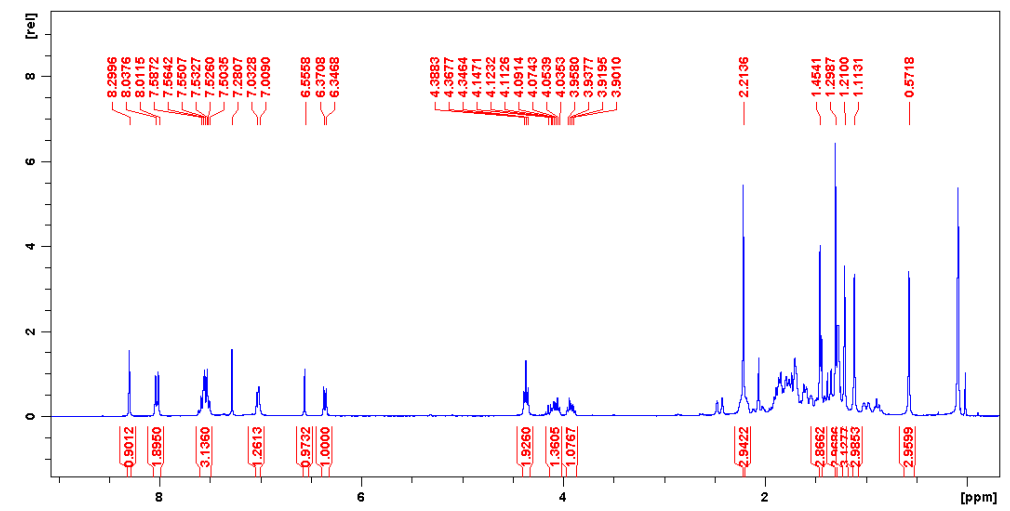

Fig. S52 ${ }^{1} \mathrm{H}$ NMR spectrum of $18\left(300 \mathrm{MHz}\right.$ in $\left.\mathrm{CDCl}_{3}\right)$

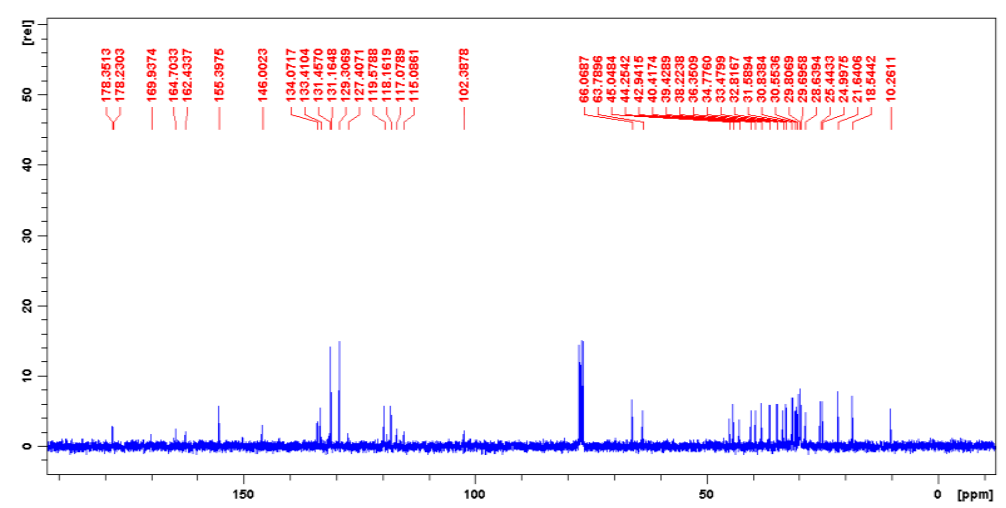

Fig. $\mathrm{S} 53{ }^{13} \mathrm{C}$ NMR spectrum of $18\left(75 \mathrm{MHz}\right.$ in $\left.\mathrm{CDCl}_{3}\right)$

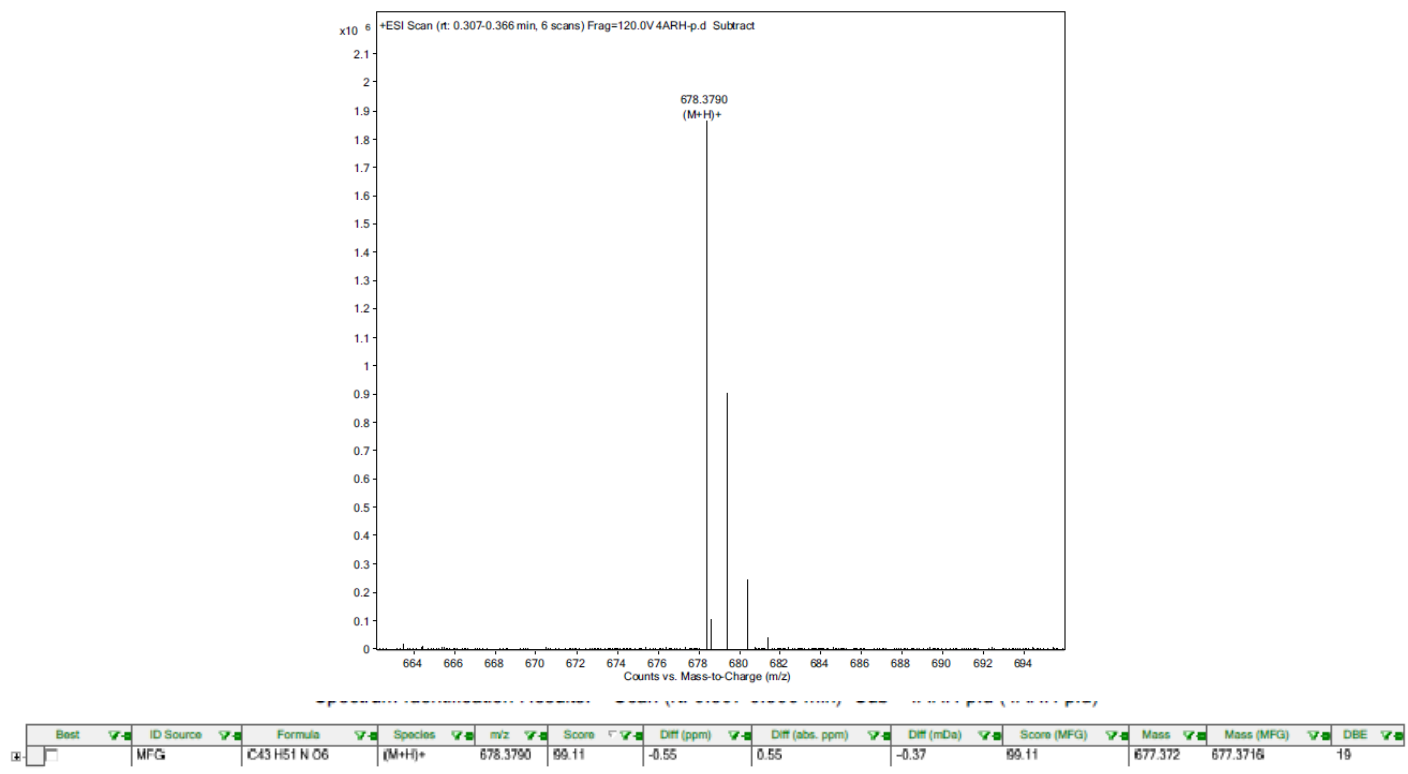

Fig. S54 ESI/HRMS spectrum of $\mathbf{1 8}$ 


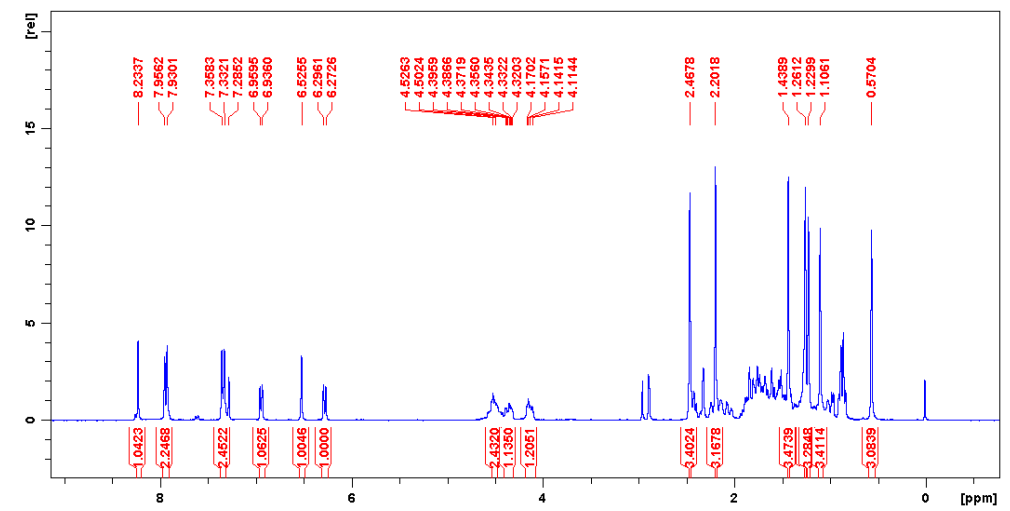

Fig. S55 ${ }^{1} \mathrm{H}$ NMR spectrum of $19\left(300 \mathrm{MHz}\right.$ in $\left.\mathrm{CDCl}_{3}\right)$

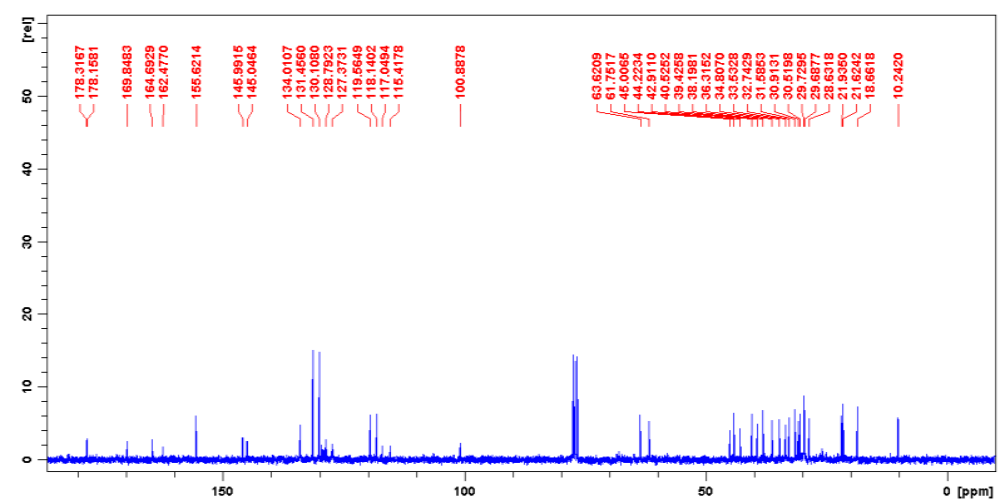

Fig. S56 ${ }^{13} \mathrm{C}$ NMR spectrum of $19\left(75 \mathrm{MHz}\right.$ in DMSO- $\left.d_{6}\right)$
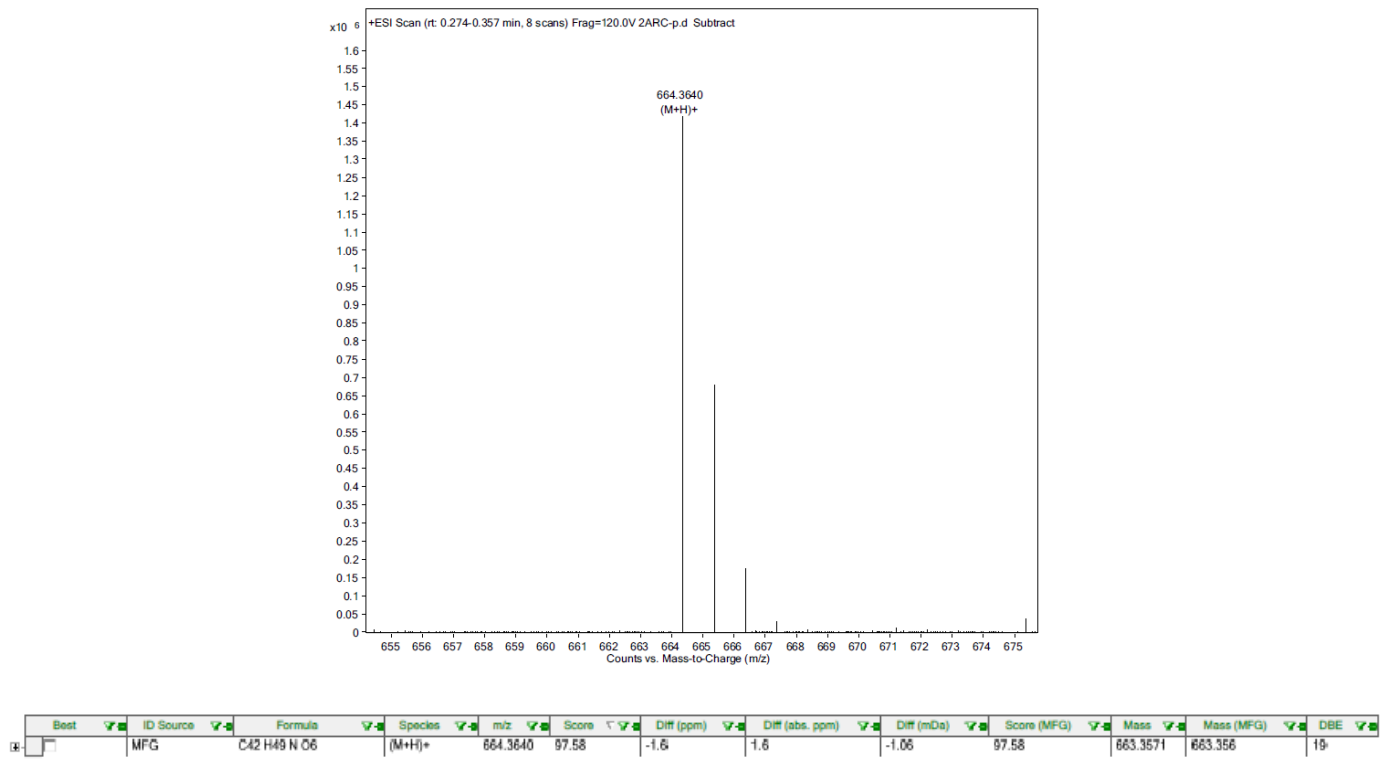

Fig. S57 ESI/HRMS spectrum of 19 


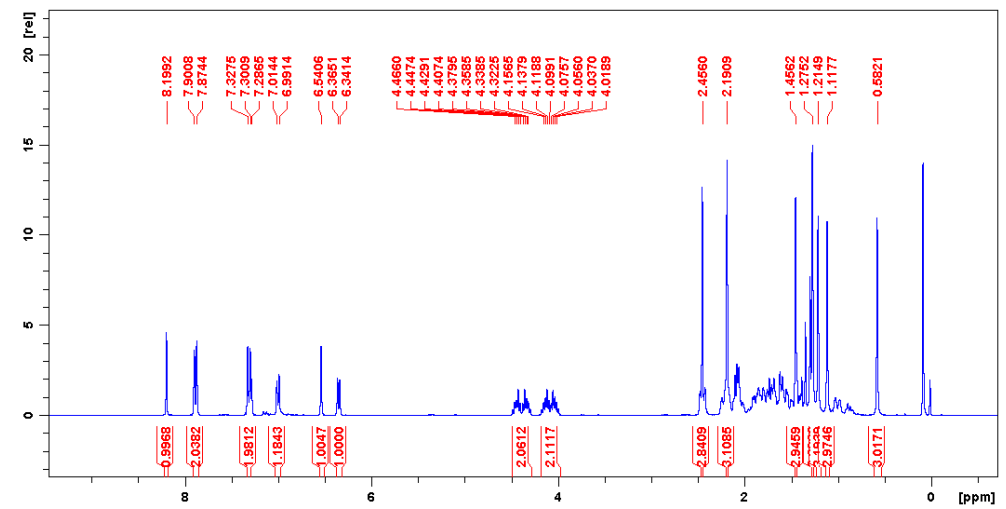

Fig. S58 ${ }^{1} \mathrm{H}$ NMR spectrum of $20\left(300 \mathrm{MHz}\right.$ in $\left.\mathrm{CDCl}_{3}\right)$

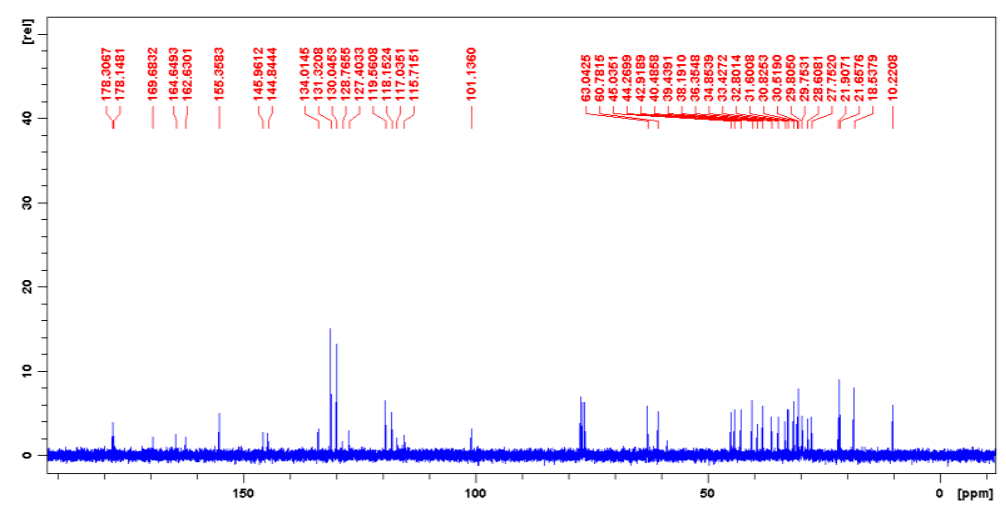

Fig. S59 ${ }^{13} \mathrm{C}$ NMR spectrum of $20\left(75 \mathrm{MHz}\right.$ in $\left.\mathrm{CDCl}_{3}\right)$
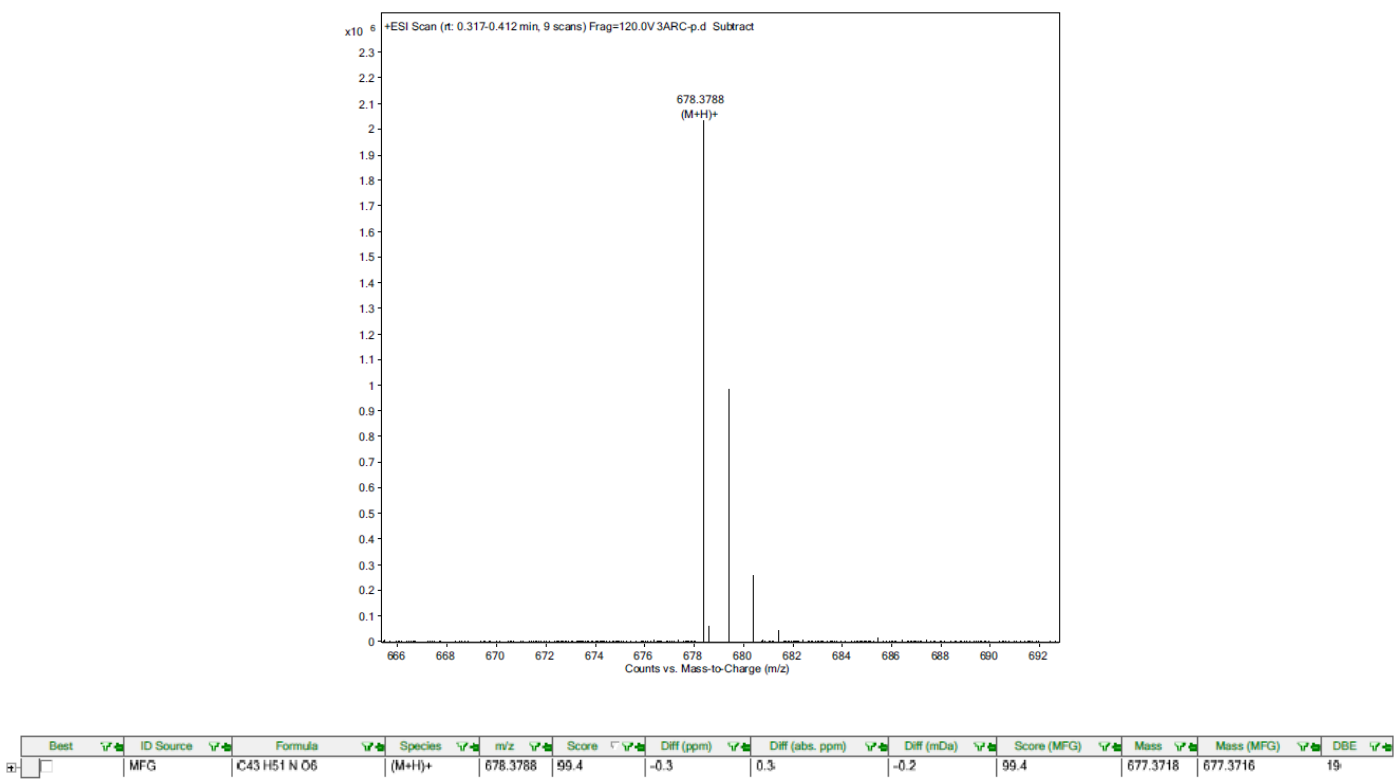

Fig. S60 ESI/HRMS spectrum of 20 


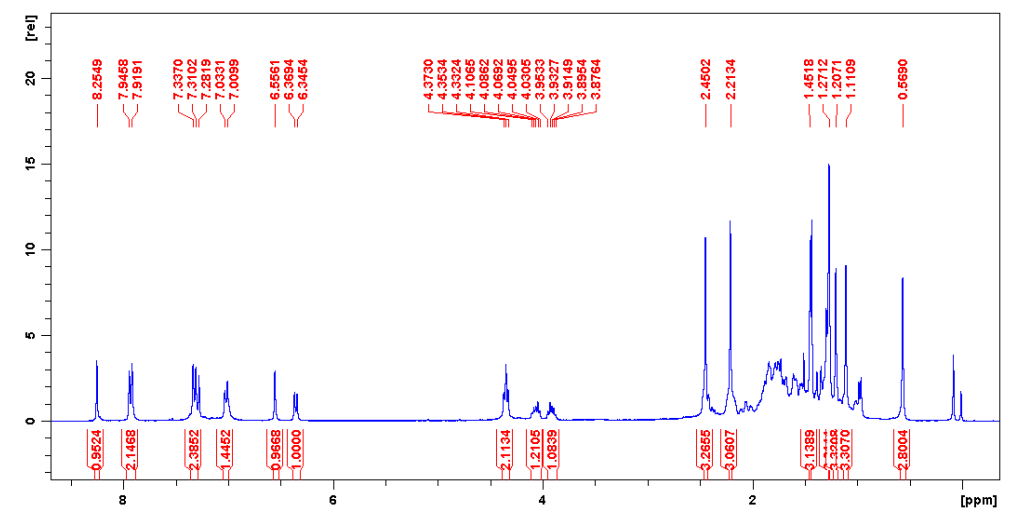

Fig. S61 ${ }^{1} \mathrm{H}$ NMR spectrum of $21\left(300 \mathrm{MHz}\right.$ in $\left.\mathrm{CDCl}_{3}\right)$

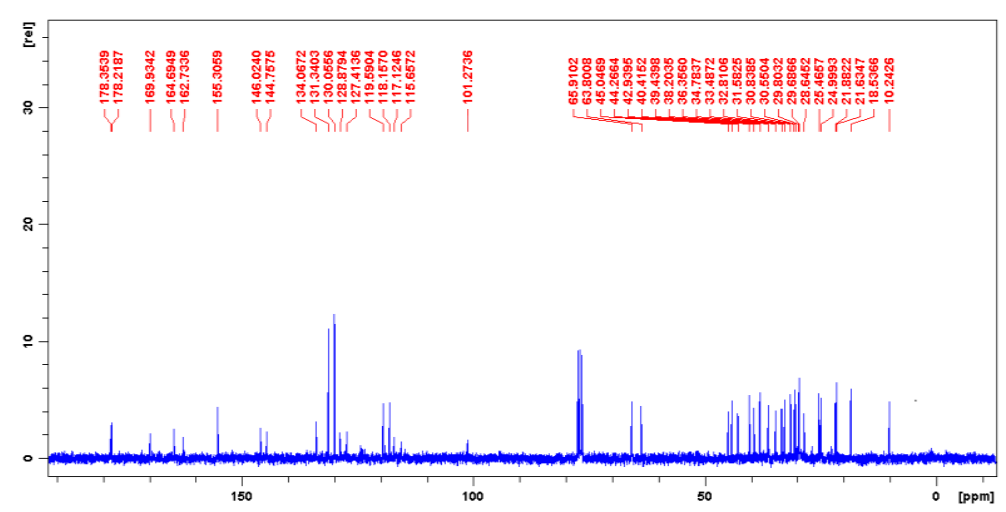

Fig. S62 ${ }^{13} \mathrm{C}$ NMR spectrum of $21\left(75 \mathrm{MHz}\right.$ in $\left.\mathrm{CDCl}_{3}\right)$

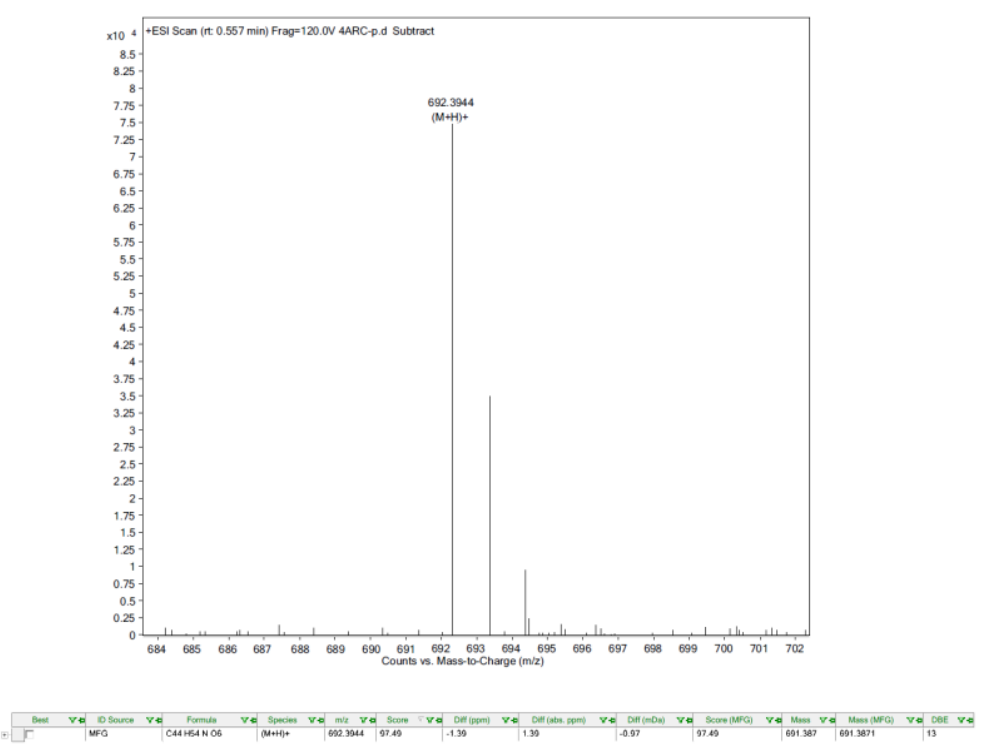

Fig. S63 ESI/HRMS spectrum of 21 


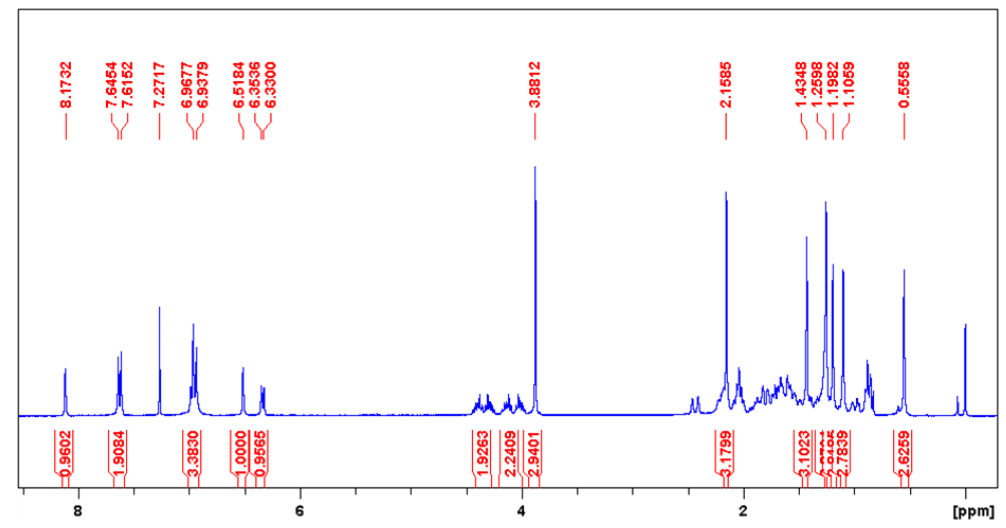

Fig. S64. ${ }^{1} \mathrm{H}$ NMR spectrum of $22\left(300 \mathrm{MHz}\right.$ in $\left.\mathrm{CDCl}_{3}\right)$

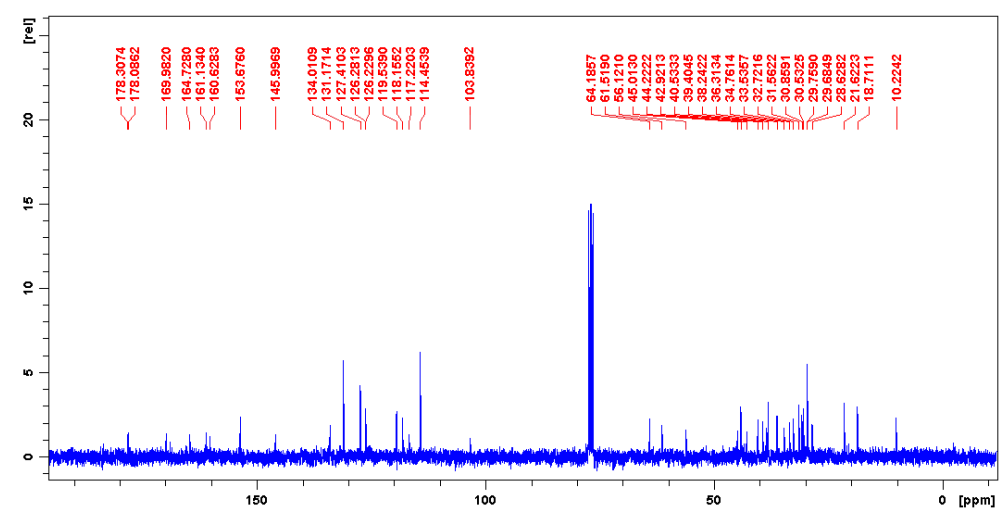

Fig. S65. ${ }^{13} \mathrm{C}$ NMR spectrum of $22\left(75 \mathrm{MHz}\right.$ in $\left.\mathrm{CDCl}_{3}\right)$

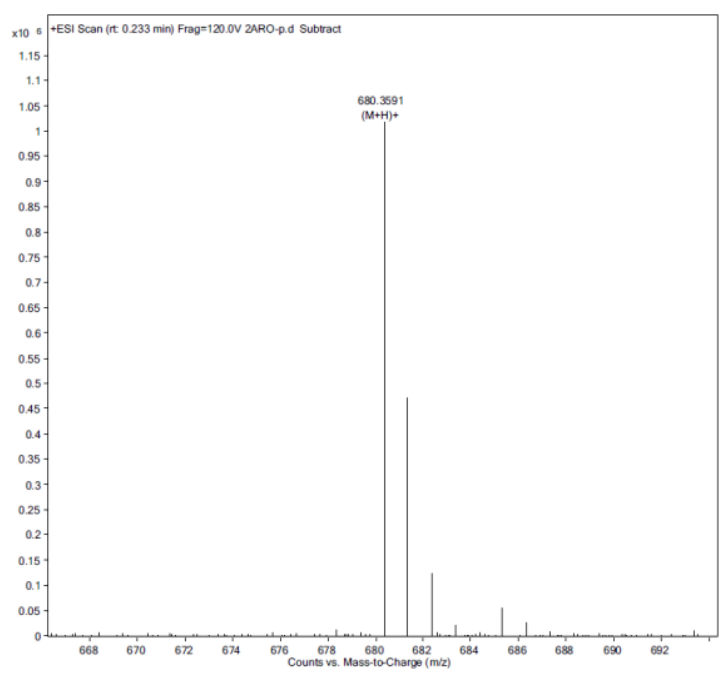

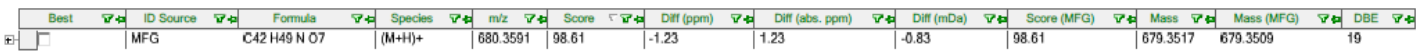

Fig. S66 ESI/HRMS spectrum of 22 


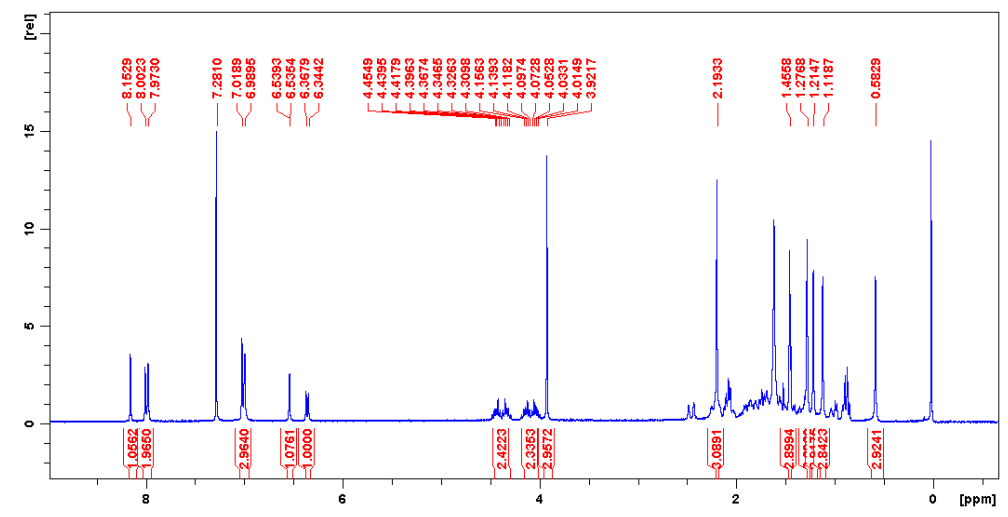

Fig. S67 ${ }^{1} \mathrm{H}$ NMR spectrum of $23\left(300 \mathrm{MHz}\right.$ in $\left.\mathrm{CDCl}_{3}\right)$

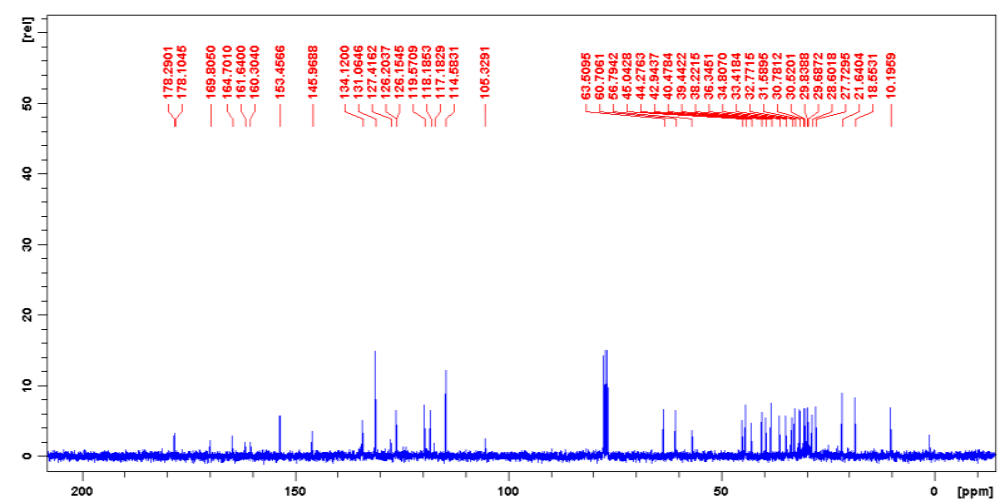

Fig. S68 ${ }^{13} \mathrm{C}$ NMR spectrum of $23\left(75 \mathrm{MHz}\right.$ in $\left.\mathrm{CDCl}_{3}\right)$

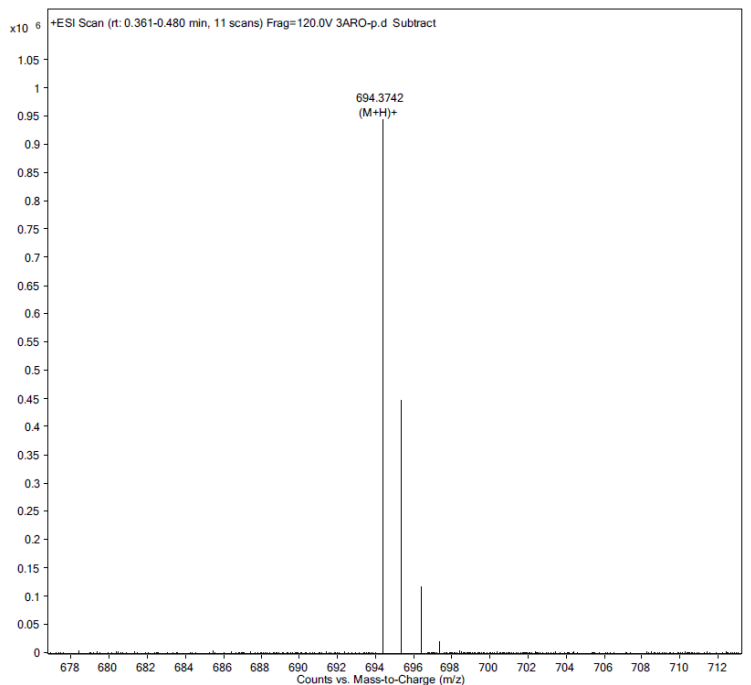

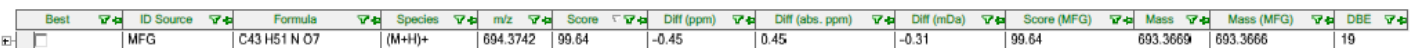

Fig. S69 ESI/HRMS spectrum of 23 


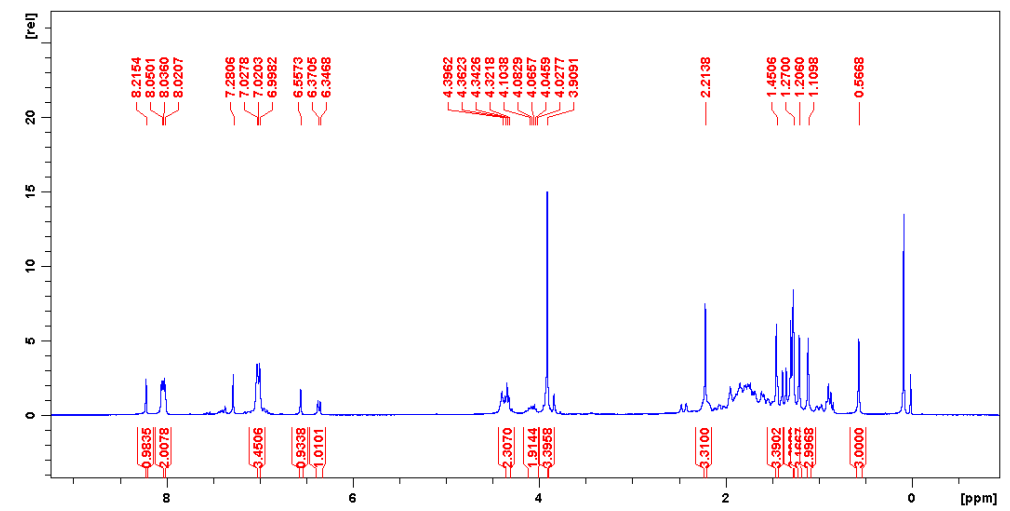

Fig. S70 ${ }^{1} \mathrm{H}$ NMR spectrum of $24\left(300 \mathrm{MHz}\right.$ in $\left.\mathrm{CDCl}_{3}\right)$

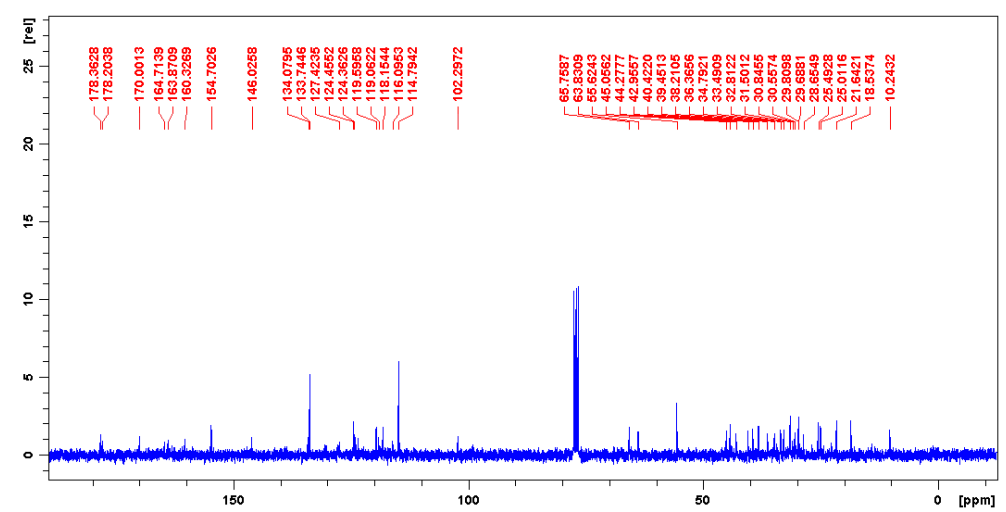

Fig. $\mathrm{S} 71{ }^{13} \mathrm{C}$ NMR spectrum of $24\left(75 \mathrm{MHz}\right.$ in $\left.\mathrm{CDCl}_{3}\right)$

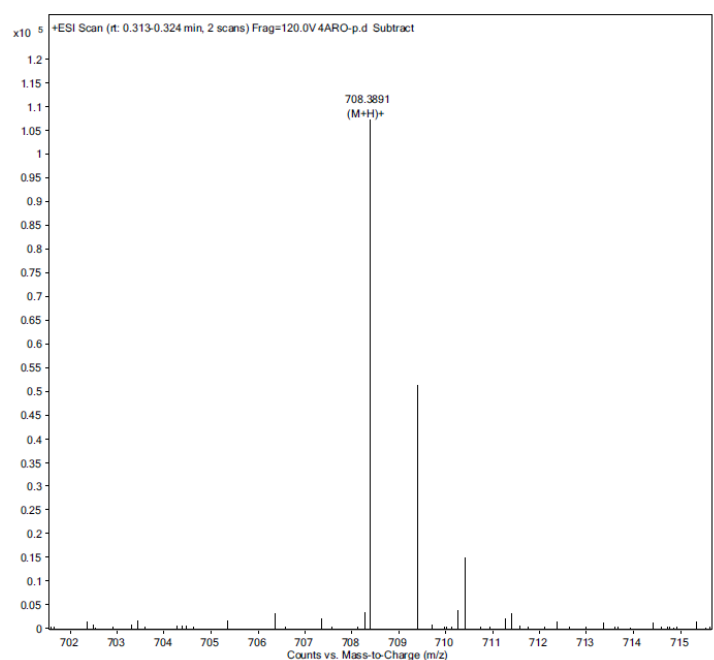

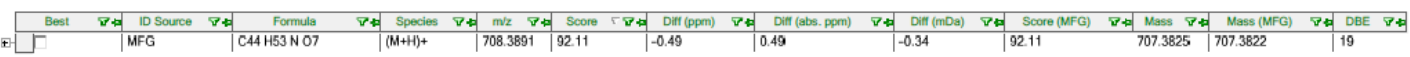

Fig. S72 ESI/HRMS spectrum of $\mathbf{2 4}$ 


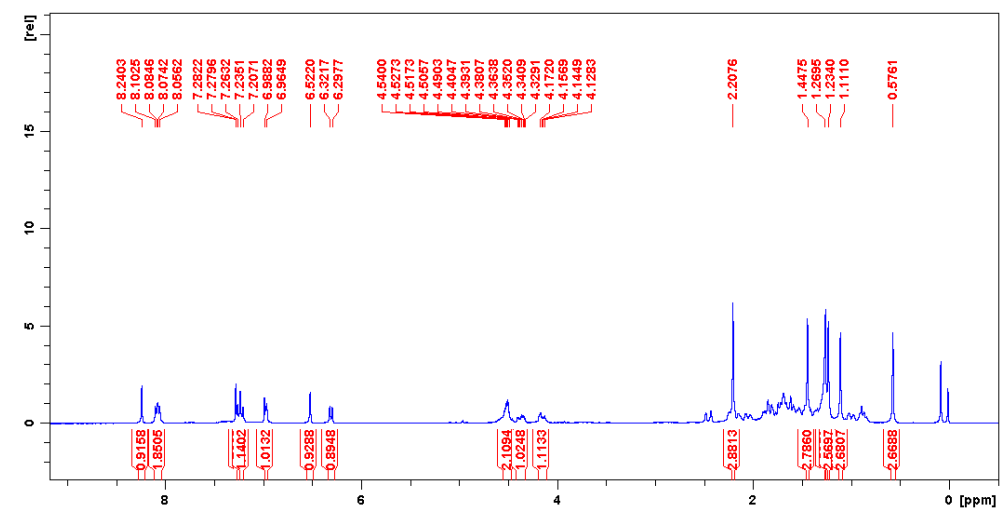

Fig. S73 ${ }^{1} \mathrm{H}$ NMR spectrum of $25\left(300 \mathrm{MHz}\right.$ in $\left.\mathrm{CDCl}_{3}\right)$

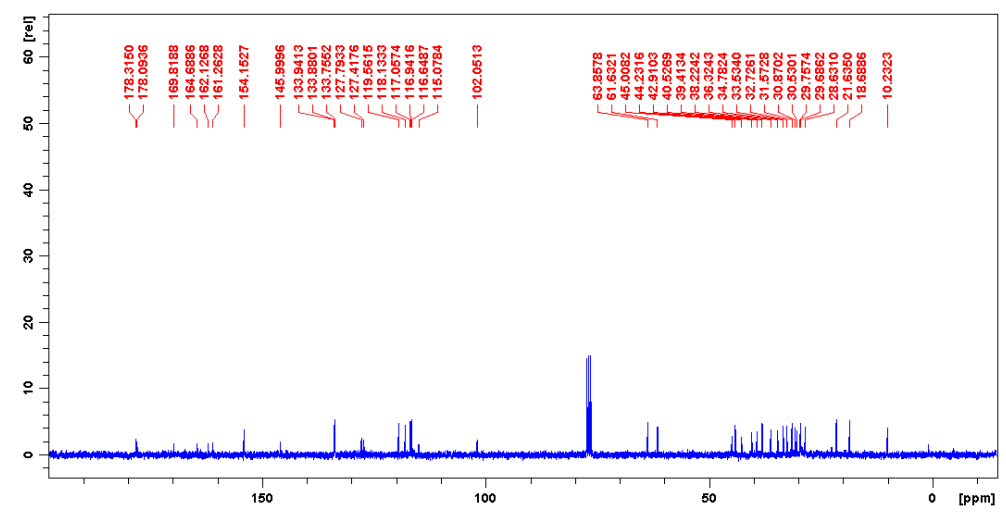

Fig. $S 74{ }^{13} \mathrm{C}$. NMR snectrum of $25\left(75 \mathrm{MHz}\right.$ in $\left.\mathrm{CDCl}_{3}\right)$

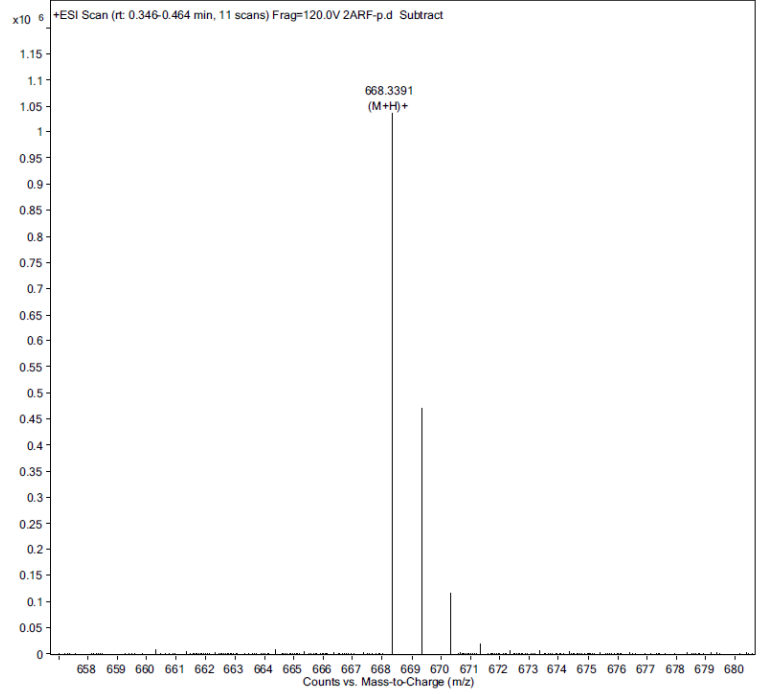

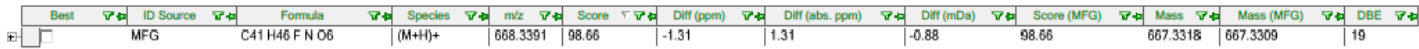

Fig. S75 ESI/HRMS spectrum of 25 


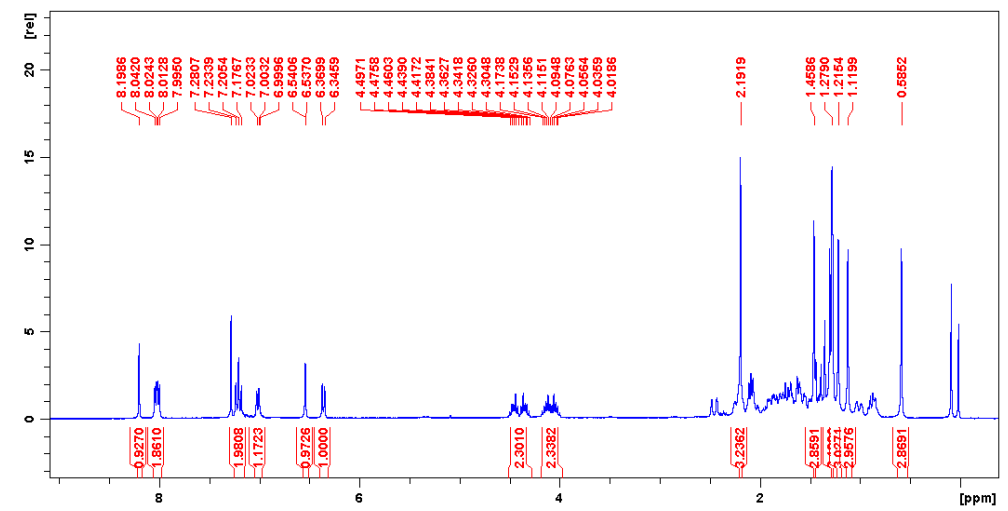

Fig. S76 ${ }^{1} \mathrm{H}$ NMR spectrum of $\mathbf{2 6}\left(300 \mathrm{MHz}\right.$ in $\left.\mathrm{CDCl}_{3}\right)$

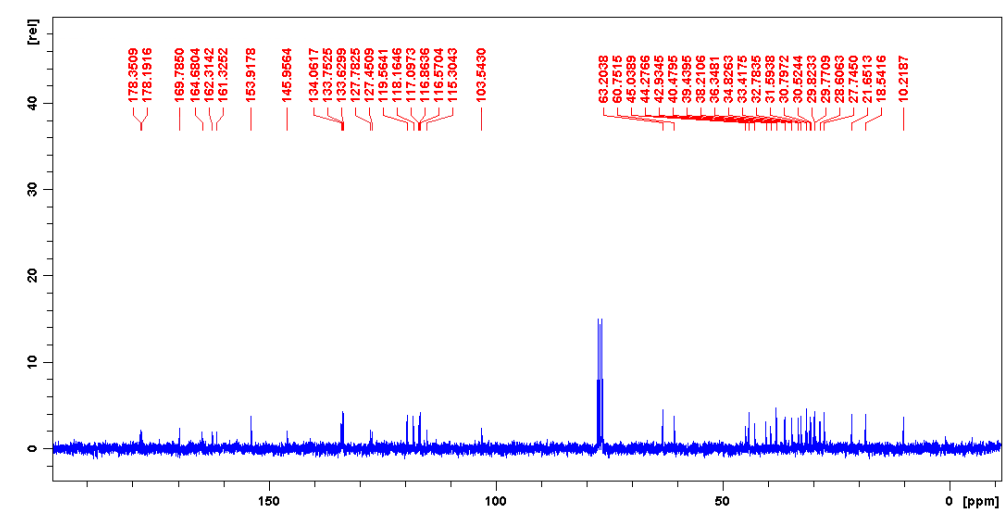

Fig. S77 ${ }^{13} \mathrm{C}$ NMR spectrum of $26\left(75 \mathrm{MHz}\right.$ in $\left.\mathrm{CDCl}_{3}\right)$
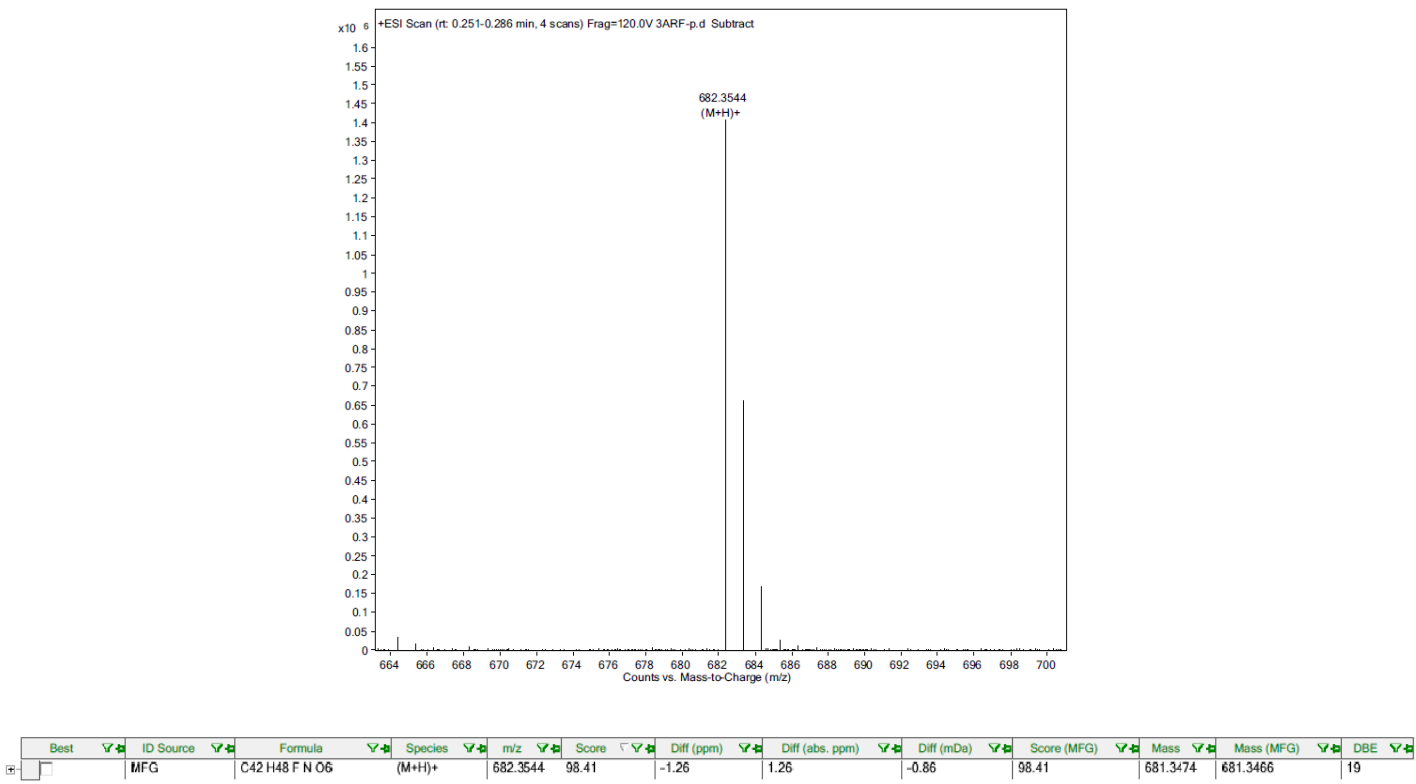

Fig. S78 ESI/HRMS spectrum of $\mathbf{2 6}$ 


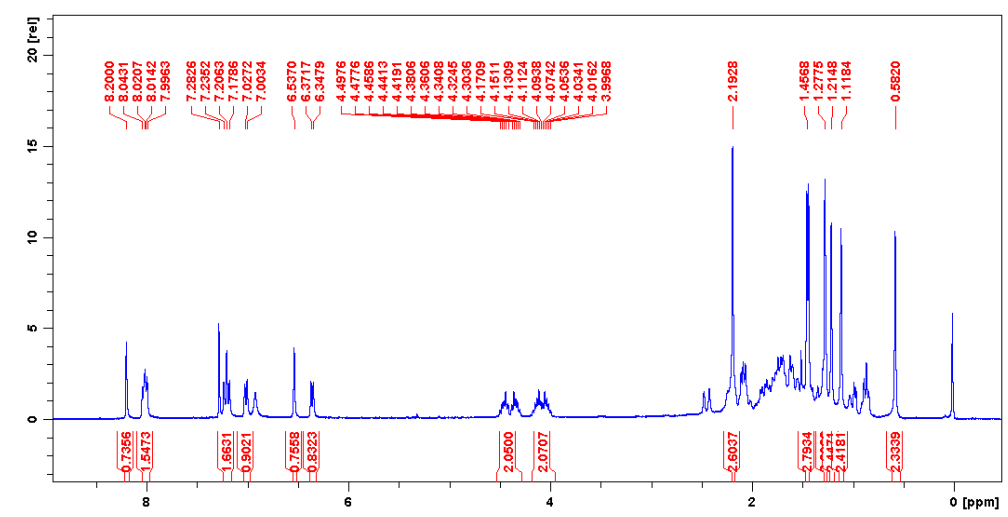

Fig. S79 ${ }^{1} \mathrm{H}$ NMR spectrum of $27\left(300 \mathrm{MHz}\right.$ in $\left.\mathrm{CDCl}_{3}\right)$

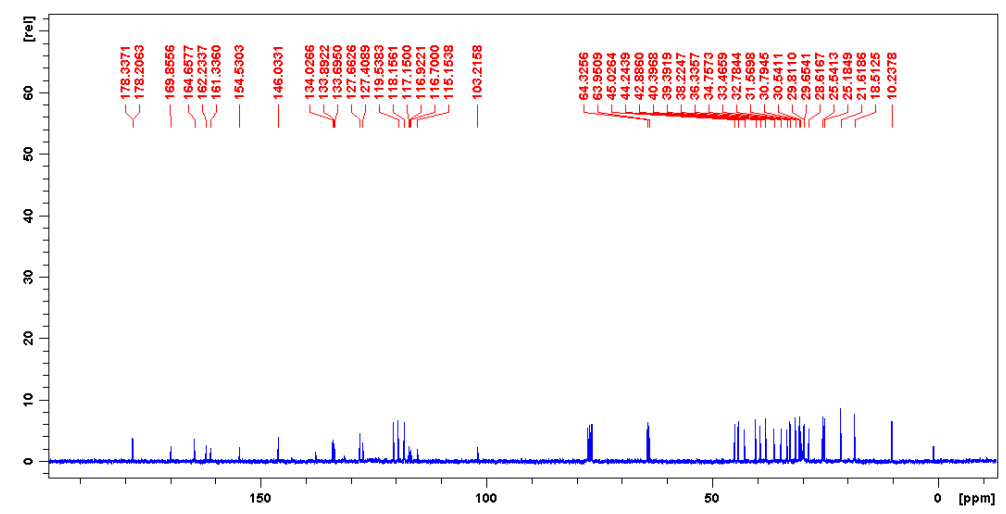

Fig. $\mathrm{S} 80{ }^{13} \mathrm{C}$ NMR spectrum of $27\left(75 \mathrm{MHz}\right.$ in $\left.\mathrm{CDCl}_{3}\right)$

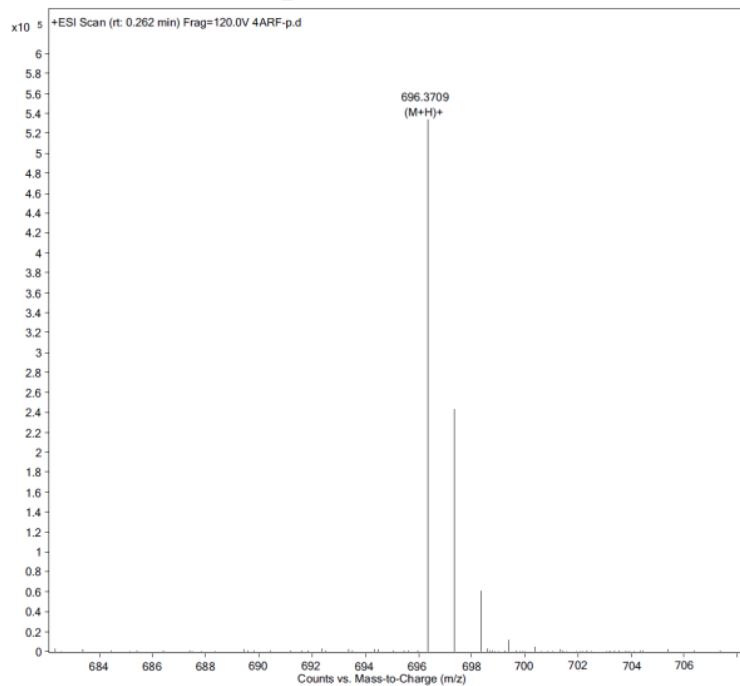

Fig. S81 ESI/HRMS spectrum of 27 


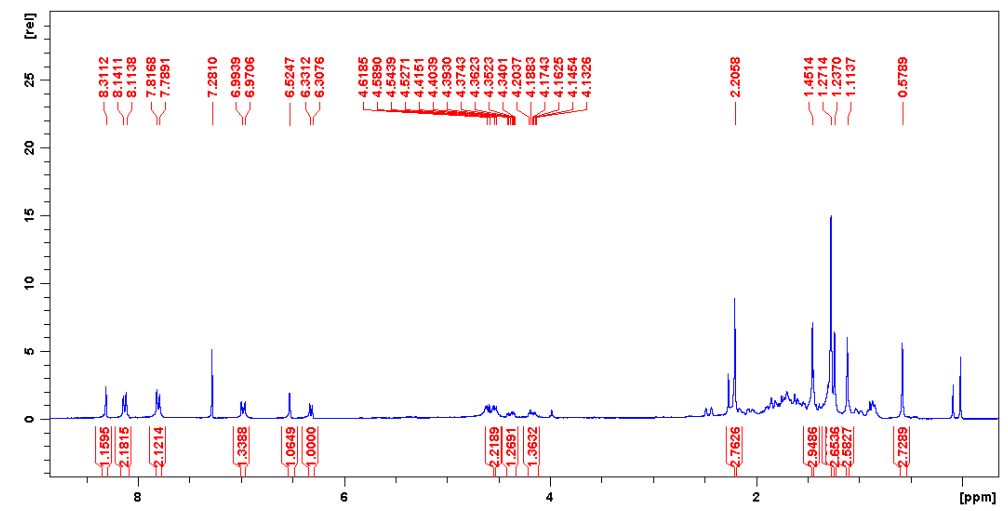

Fig. S82 ${ }^{1} \mathrm{H}$ NMR spectrum of $28\left(300 \mathrm{MHz}\right.$ in $\left.\mathrm{CDCl}_{3}\right)$

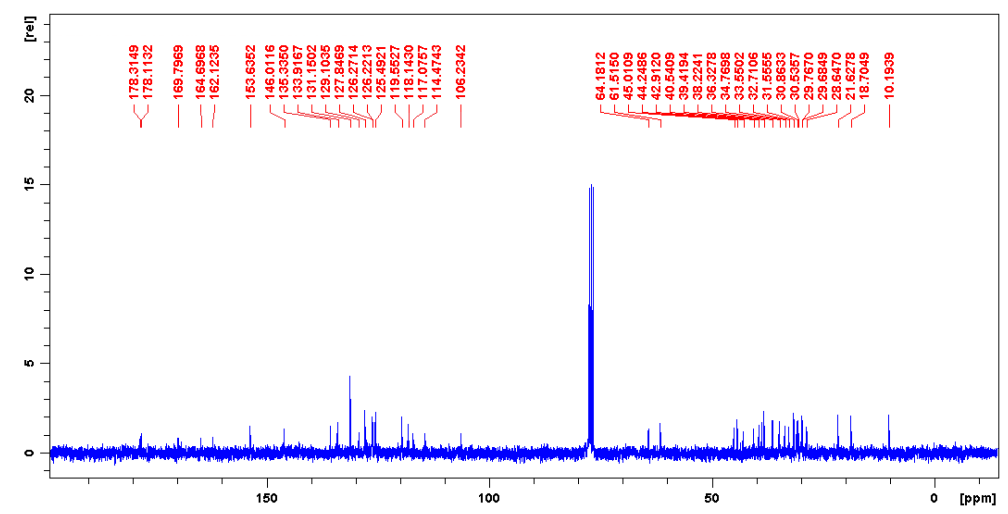

Fig. S83 ${ }^{13} \mathrm{C}$ NMR spectrum of $28\left(75 \mathrm{MHz}\right.$ in $\left.\mathrm{CDCl}_{3}\right)$

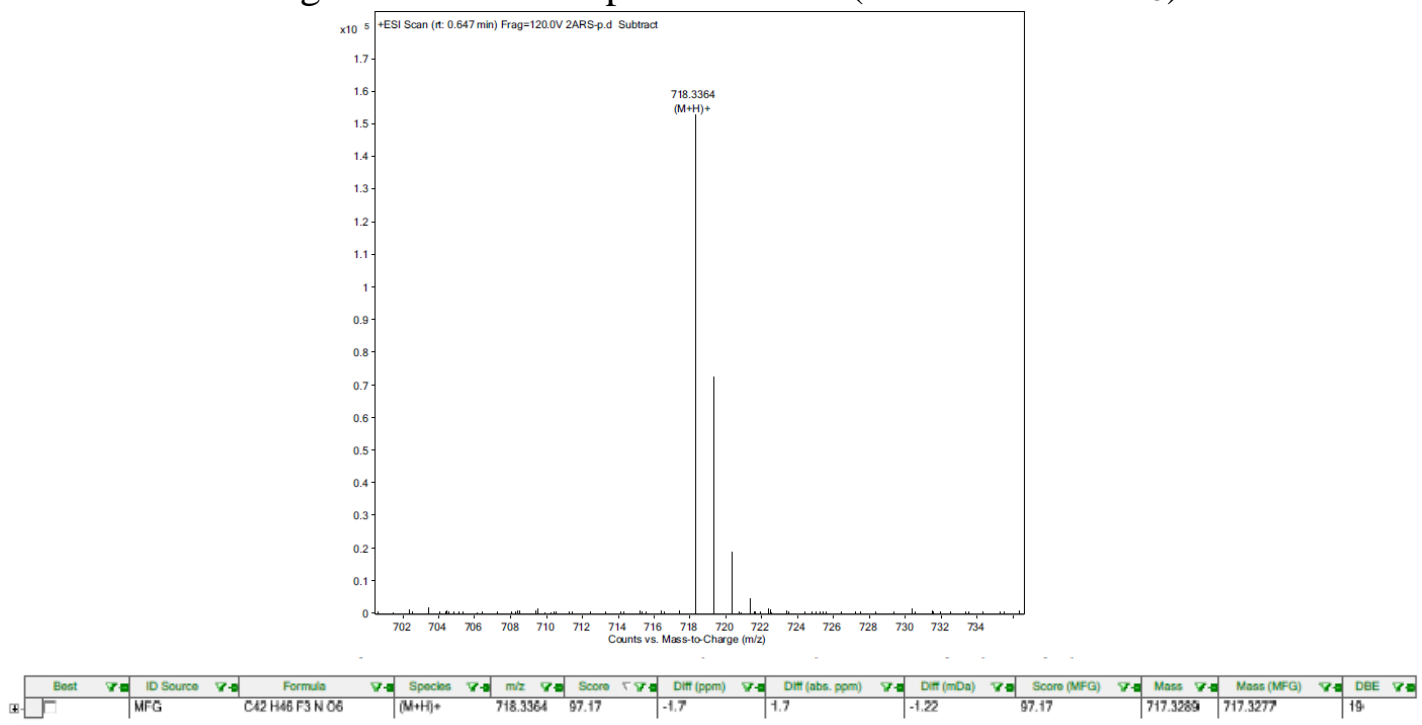

Fig. S84 ESI/HRMS spectrum of 28 


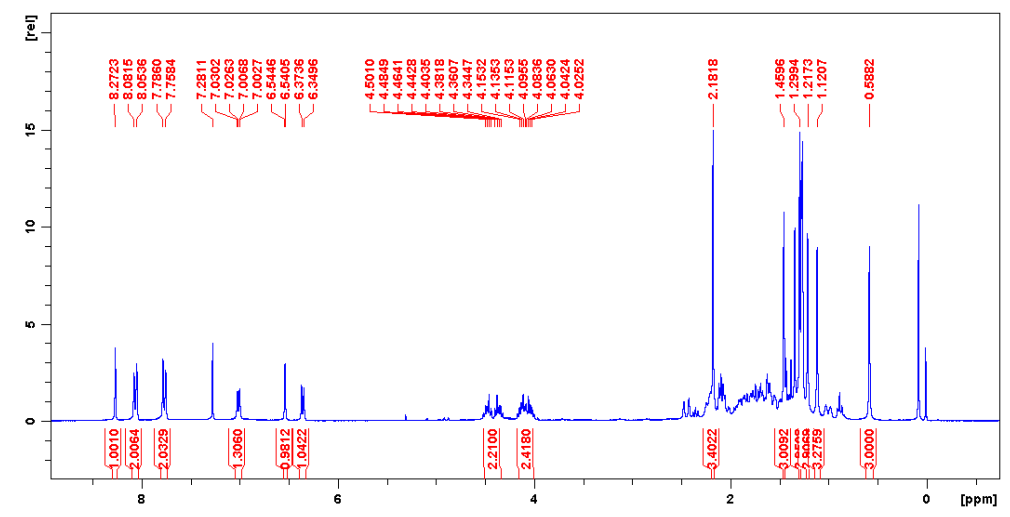

Fig. S85 ${ }^{1} \mathrm{H}$ NMR spectrum of $29\left(300 \mathrm{MHz}\right.$ in $\left.\mathrm{CDCl}_{3}\right)$

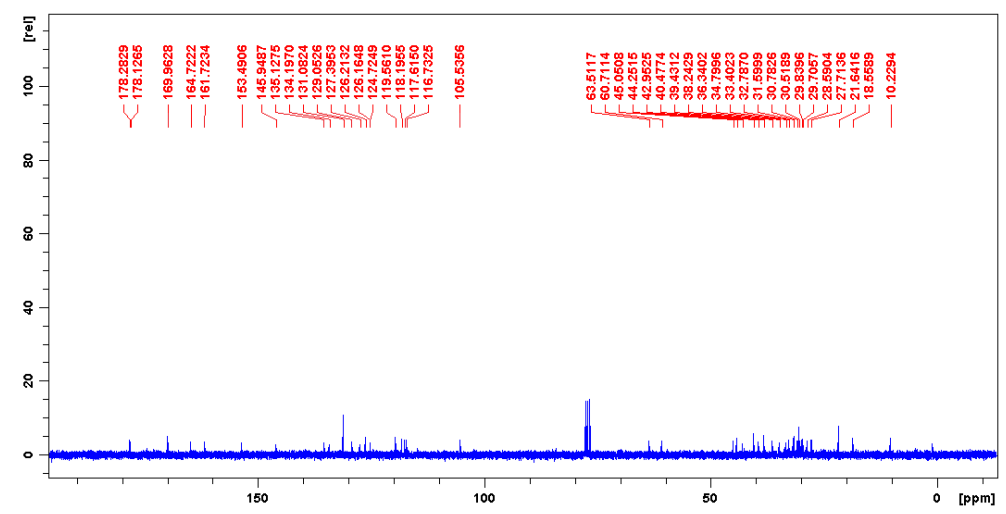

Fig. S86 ${ }^{13} \mathrm{C}$ NMR spectrum of $29\left(75 \mathrm{MHz}\right.$ in DMSO- $\left.d_{6}\right)$
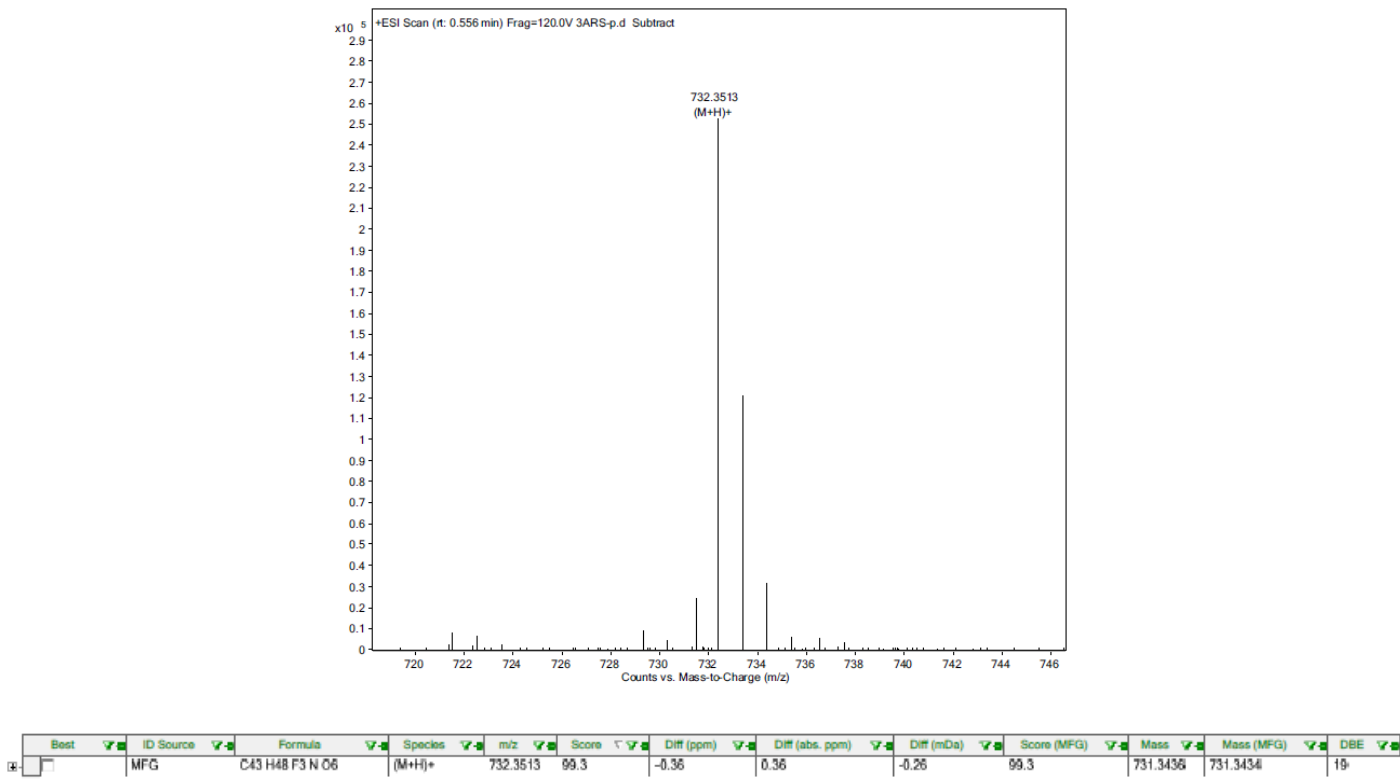

Fig. S87 ESI/HRMS spectrum of 29 


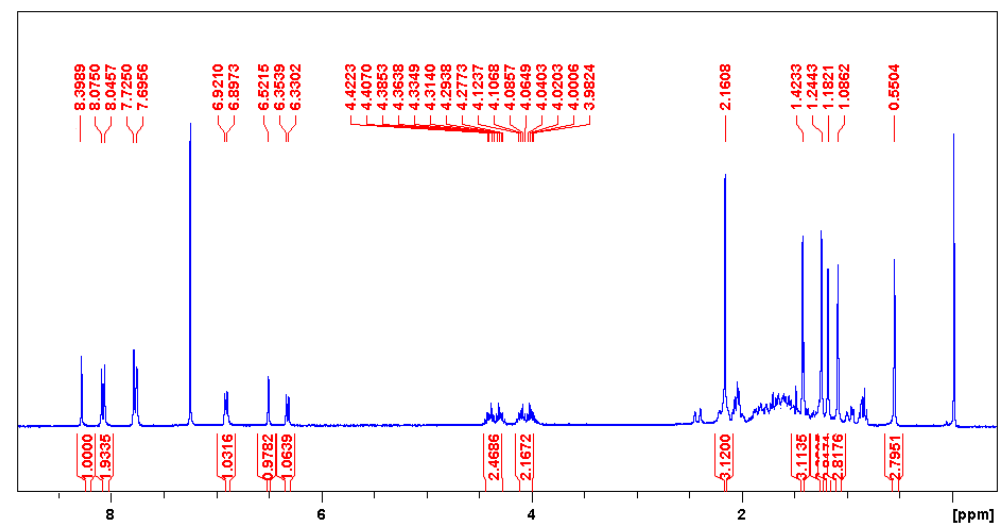

Fig. S88 ${ }^{1} \mathrm{H}$ NMR spectrum of $\mathbf{3 0}\left(300 \mathrm{MHz}\right.$ in $\left.\mathrm{CDCl}_{3}\right)$

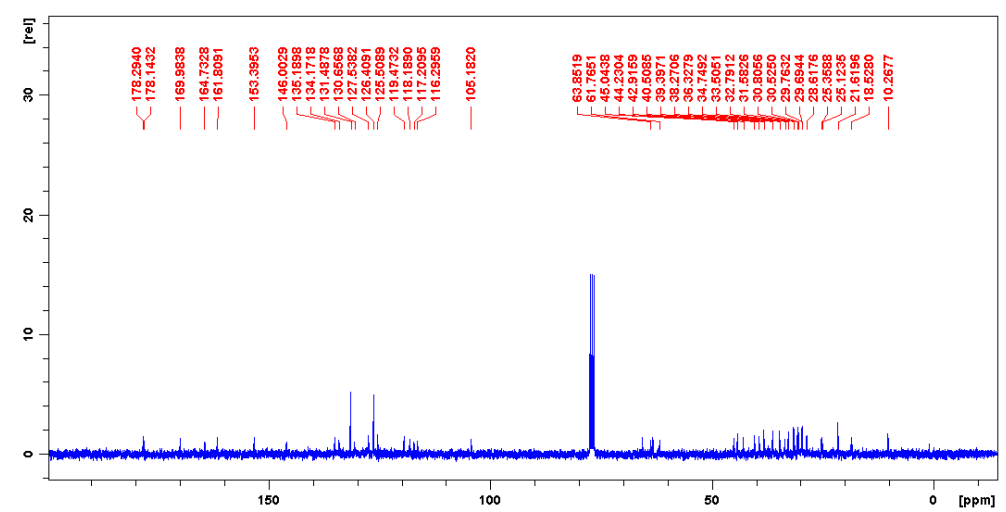

Fig. S89 ${ }^{13} \mathrm{C}$ NMR spectrum of $\mathbf{3 0}\left(75 \mathrm{MHz}\right.$ in $\left.\mathrm{CDCl}_{3}\right)$

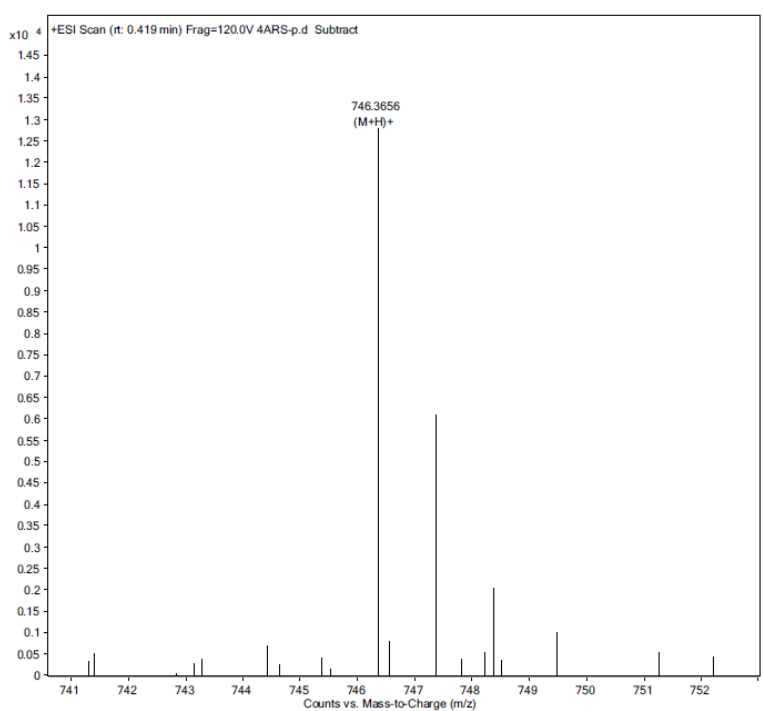

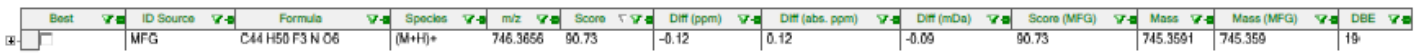

Fig. S90 ESI/HRMS spectrum of $\mathbf{3 0}$ 


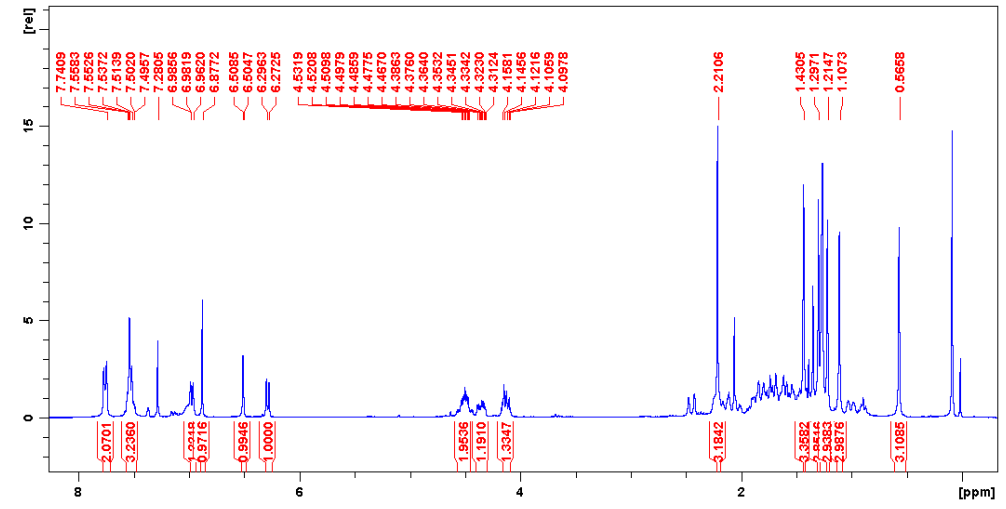

Fig. S91 ${ }^{1} \mathrm{H}$ NMR spectrum of $\mathbf{3 1}\left(300 \mathrm{MHz}\right.$ in $\left.\mathrm{CDCl}_{3}\right)$

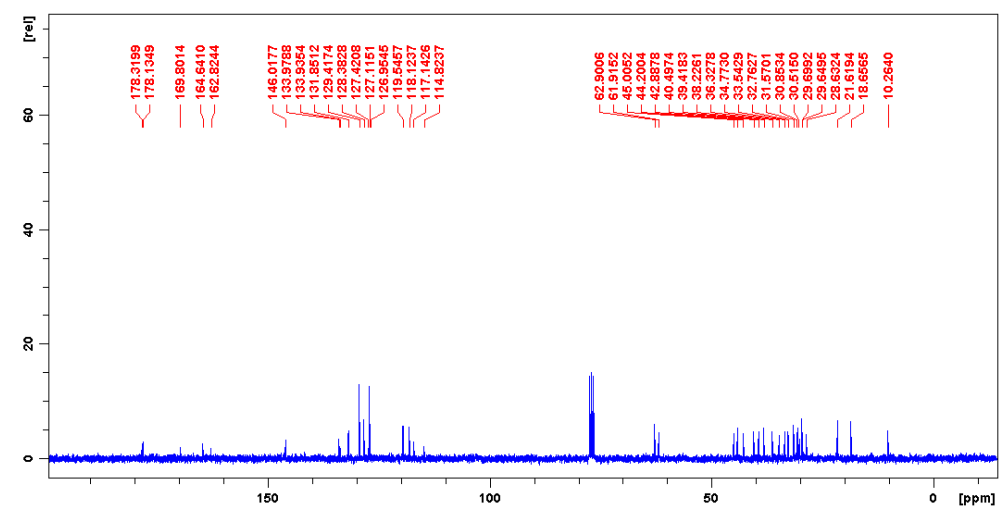

Fig. S92 ${ }^{13} \mathrm{C}$ NMR spectrum of $\mathbf{3 1}\left(75 \mathrm{MHz}\right.$ in $\left.\mathrm{CDCl}_{3}\right)$
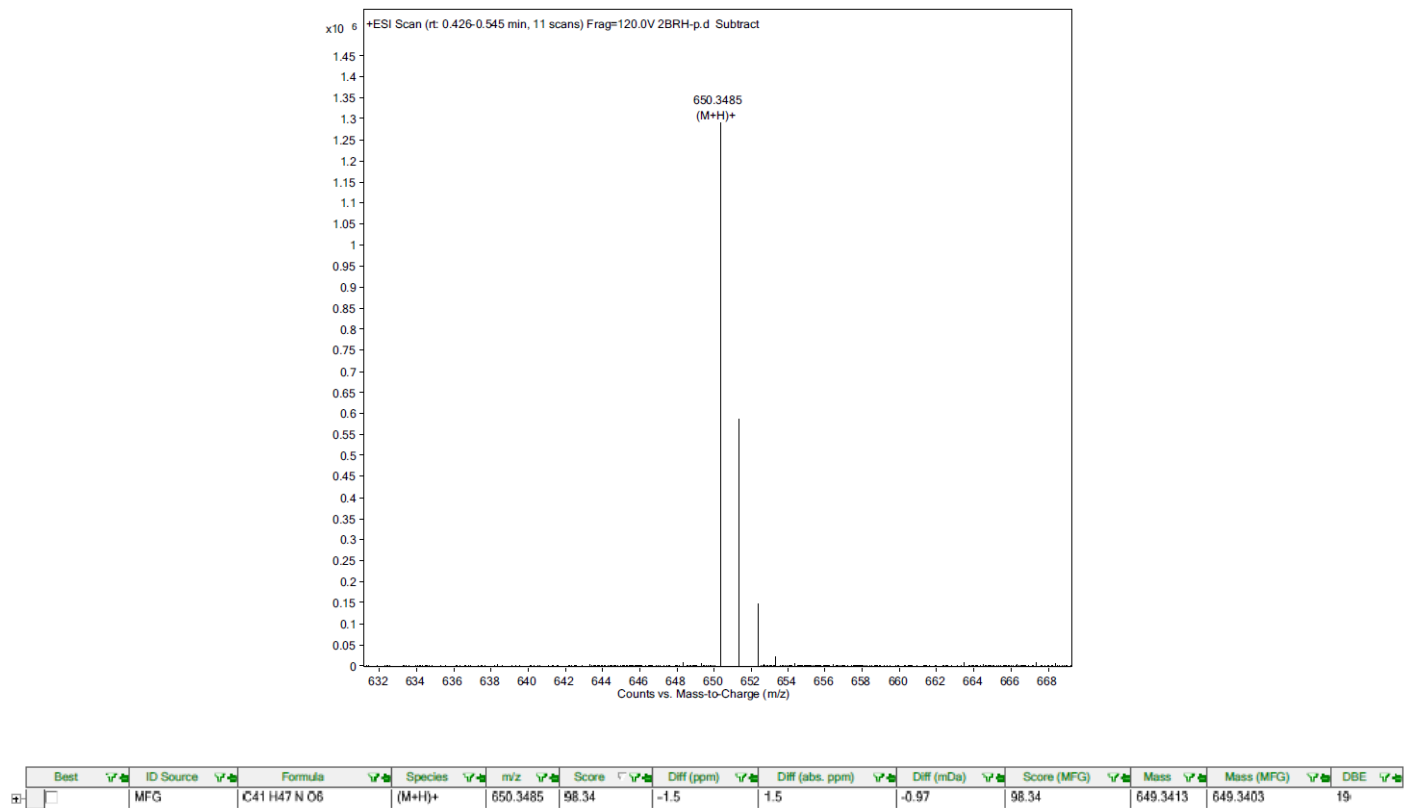

Fig. S93 ESI/HRMS spectrum of $\mathbf{3 1}$ 


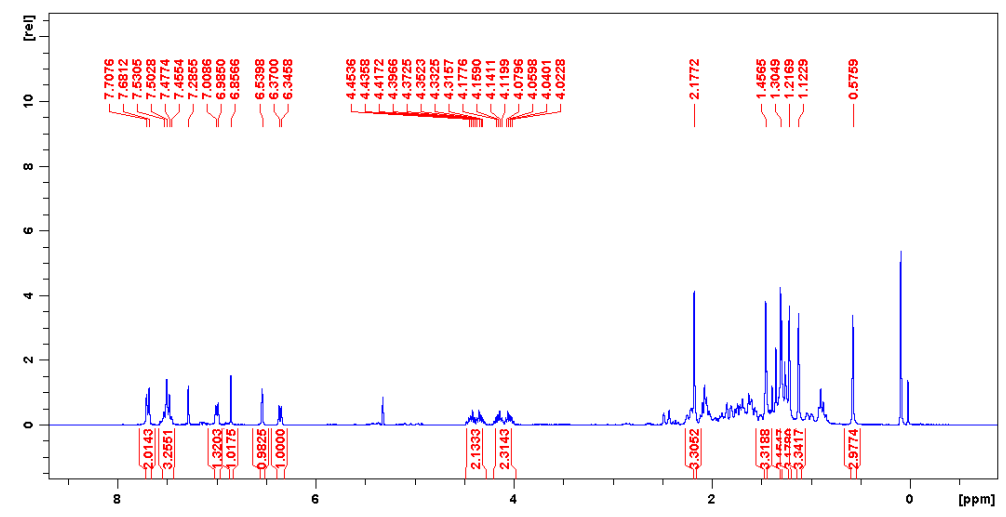

Fig. S94. ${ }^{1} \mathrm{H}$ NMR spectrum of $32\left(300 \mathrm{MHz}\right.$ in $\left.\mathrm{CDCl}_{3}\right)$

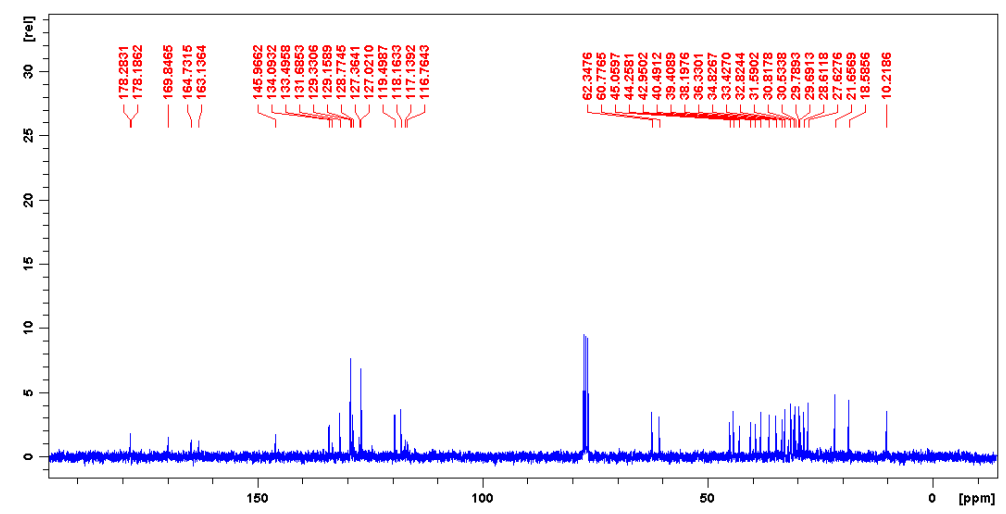

Fig. S95. ${ }^{13} \mathrm{C}$ NMR spectrum of $32\left(75 \mathrm{MHz}\right.$ in $\left.\mathrm{CDCl}_{3}\right)$
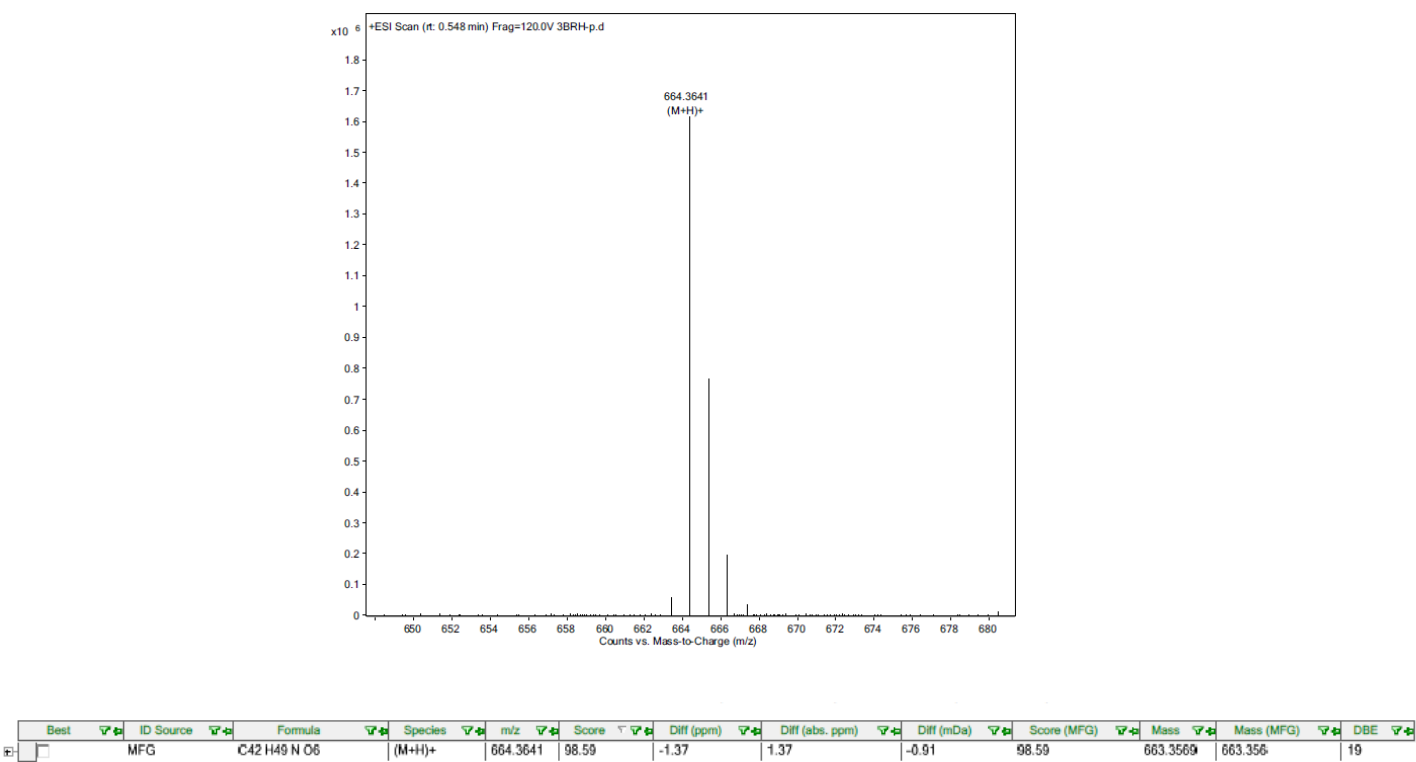

Fig. S96 ESI/HRMS spectrum of $\mathbf{3 2}$ 


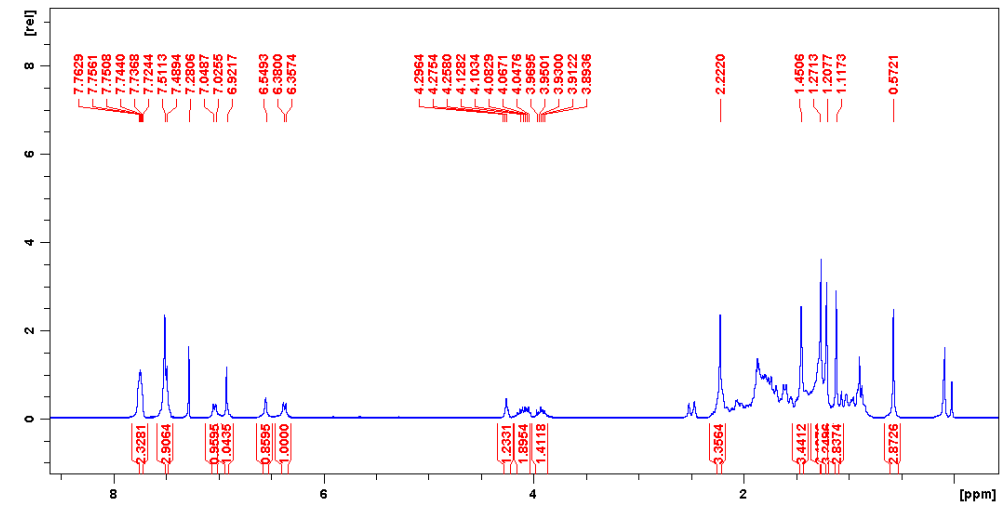

Fig. S97 ${ }^{1} \mathrm{H}$ NMR spectrum of $33\left(300 \mathrm{MHz}\right.$ in $\left.\mathrm{CDCl}_{3}\right)$

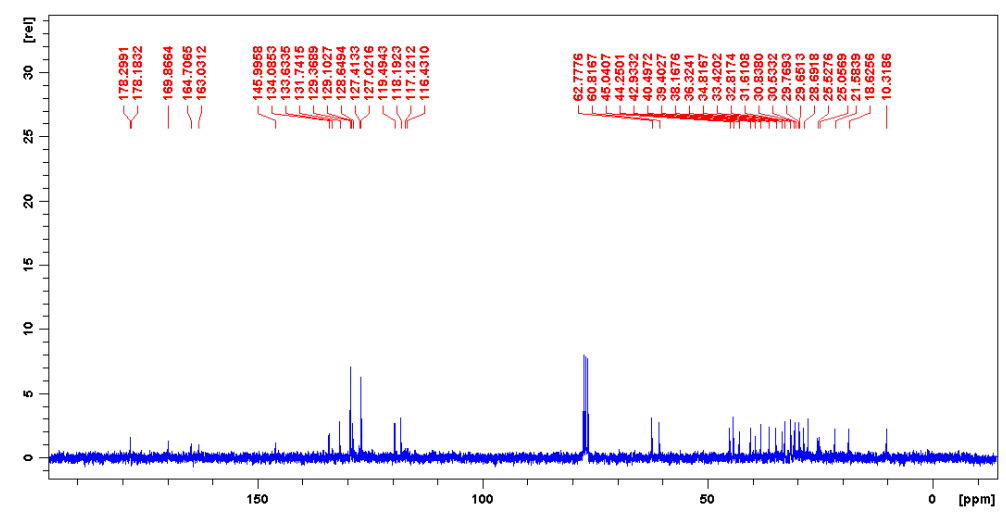

Fig. S98 ${ }^{13} \mathrm{C}$ NMR spectrum of $\mathbf{3 3}\left(75 \mathrm{MHz}\right.$ in $\left.\mathrm{CDCl}_{3}\right)$
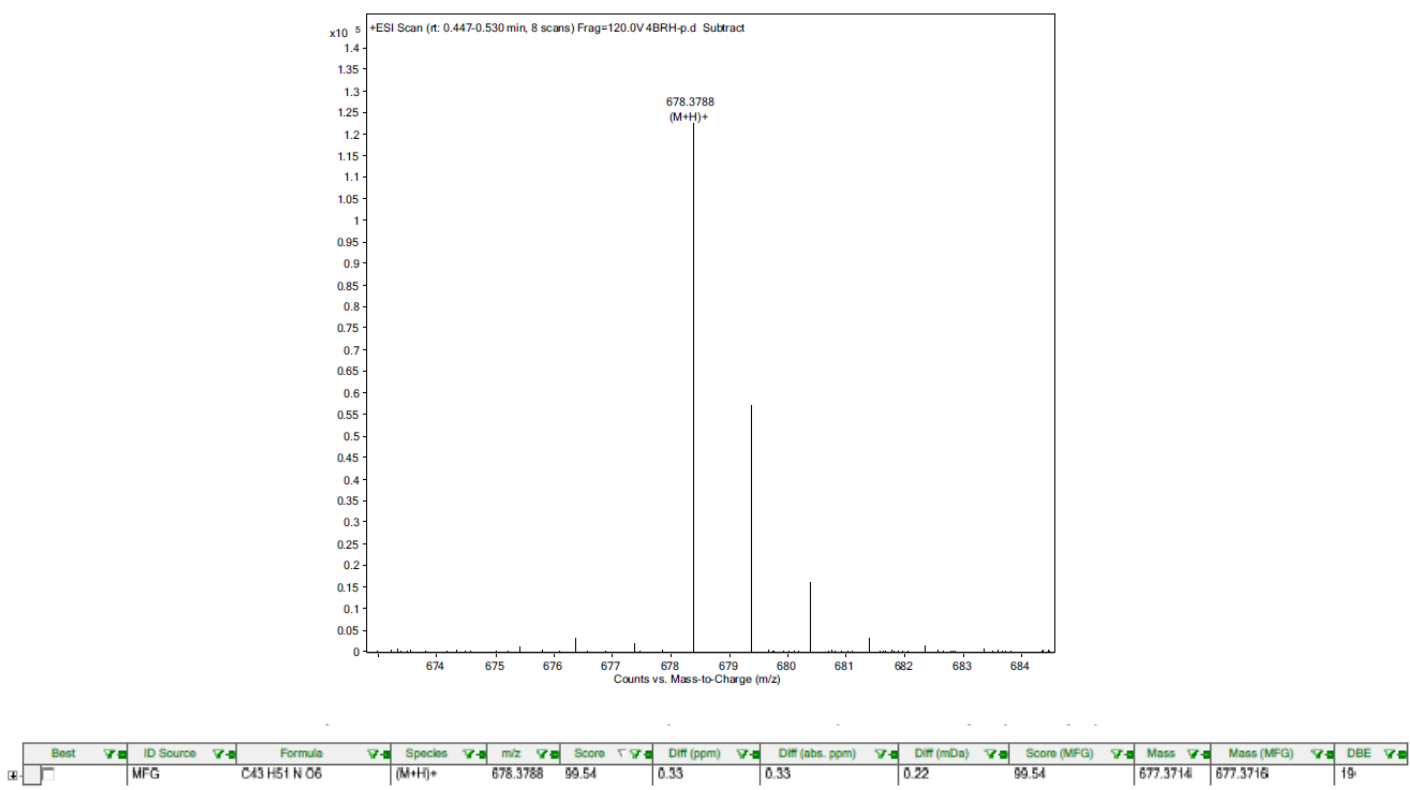

Fig. S99 ESI/HRMS spectrum of $\mathbf{3 3}$ 


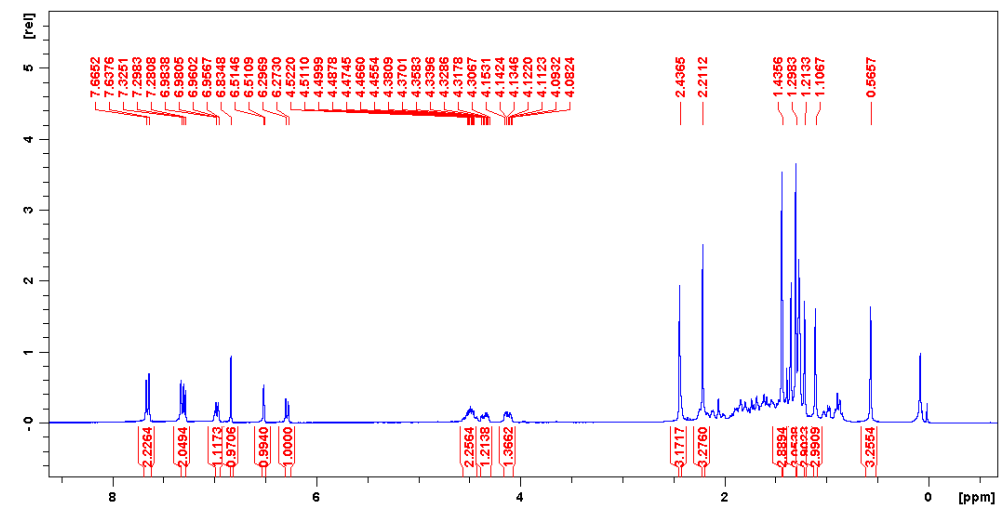

Fig. S100 ${ }^{1} \mathrm{H}$ NMR spectrum of $\mathbf{3 4}\left(300 \mathrm{MHz}\right.$ in $\left.\mathrm{CDCl}_{3}\right)$

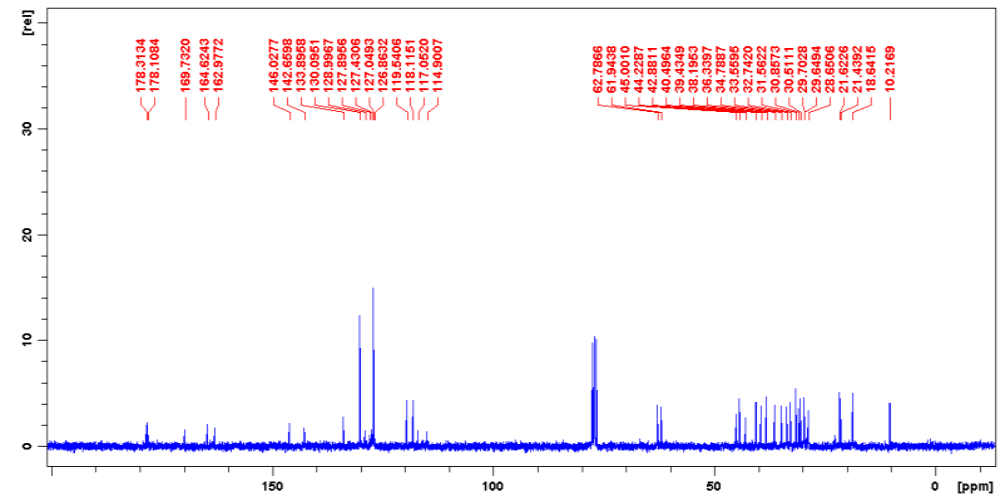

Fig. S101 ${ }^{13} \mathrm{C}$ NMR spectrum of $\mathbf{3 4}\left(75 \mathrm{MHz}\right.$ in $\left.\mathrm{CDCl}_{3}\right)$

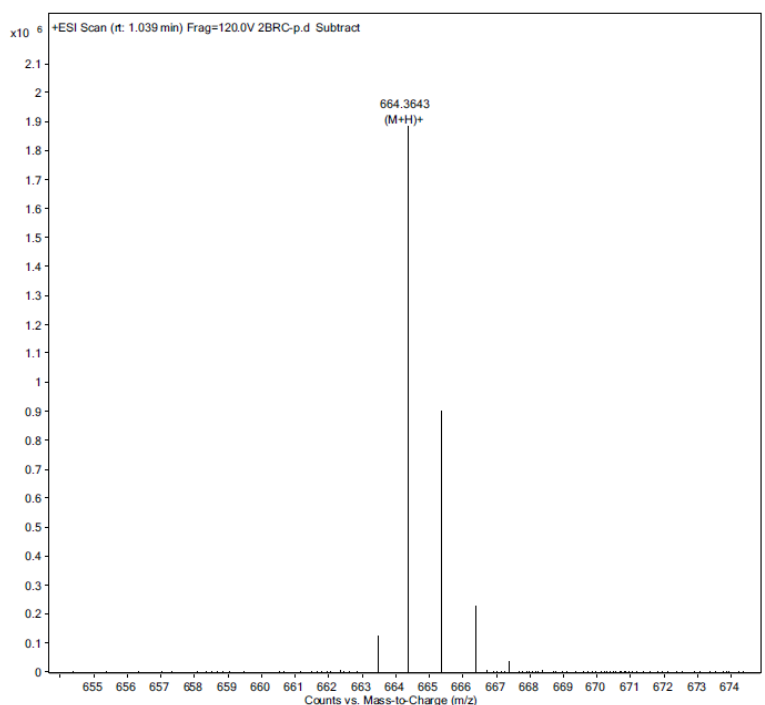

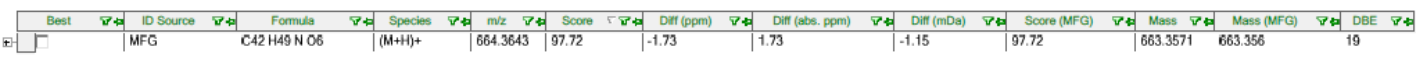

Fig. S102 ESI/HRMS spectrum of $\mathbf{3 4}$ 


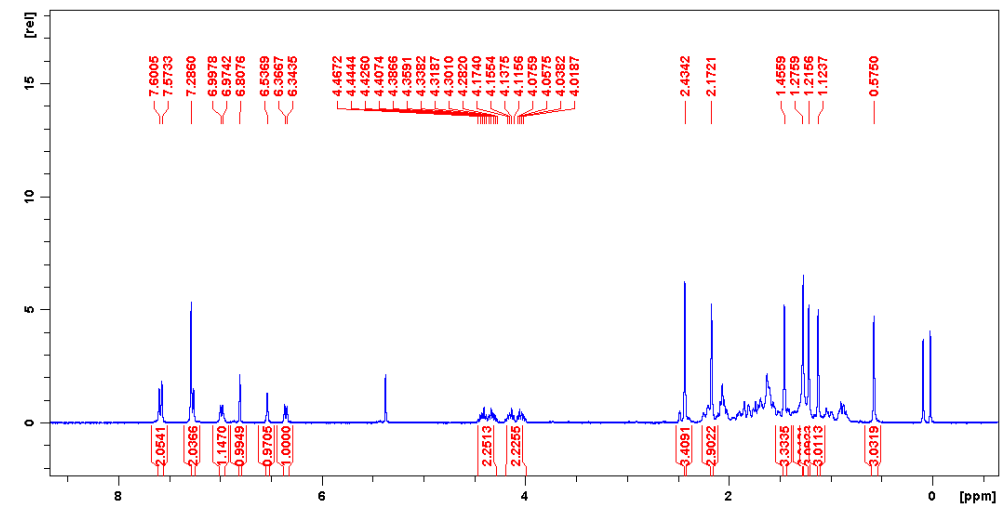

Fig. S103 ${ }^{1} \mathrm{H}$ NMR spectrum of $35\left(300 \mathrm{MHz}\right.$ in $\left.\mathrm{CDCl}_{3}\right)$

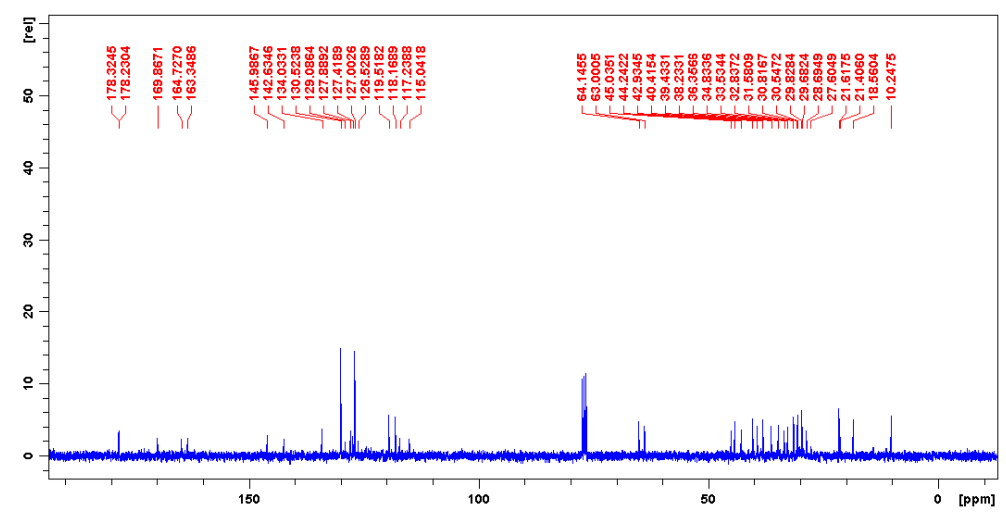

Fig. S104 ${ }^{13} \mathrm{C}$ NMR spectrum of $\mathbf{3 5}\left(75 \mathrm{MHz}\right.$ in $\left.\mathrm{CDCl}_{3}\right)$
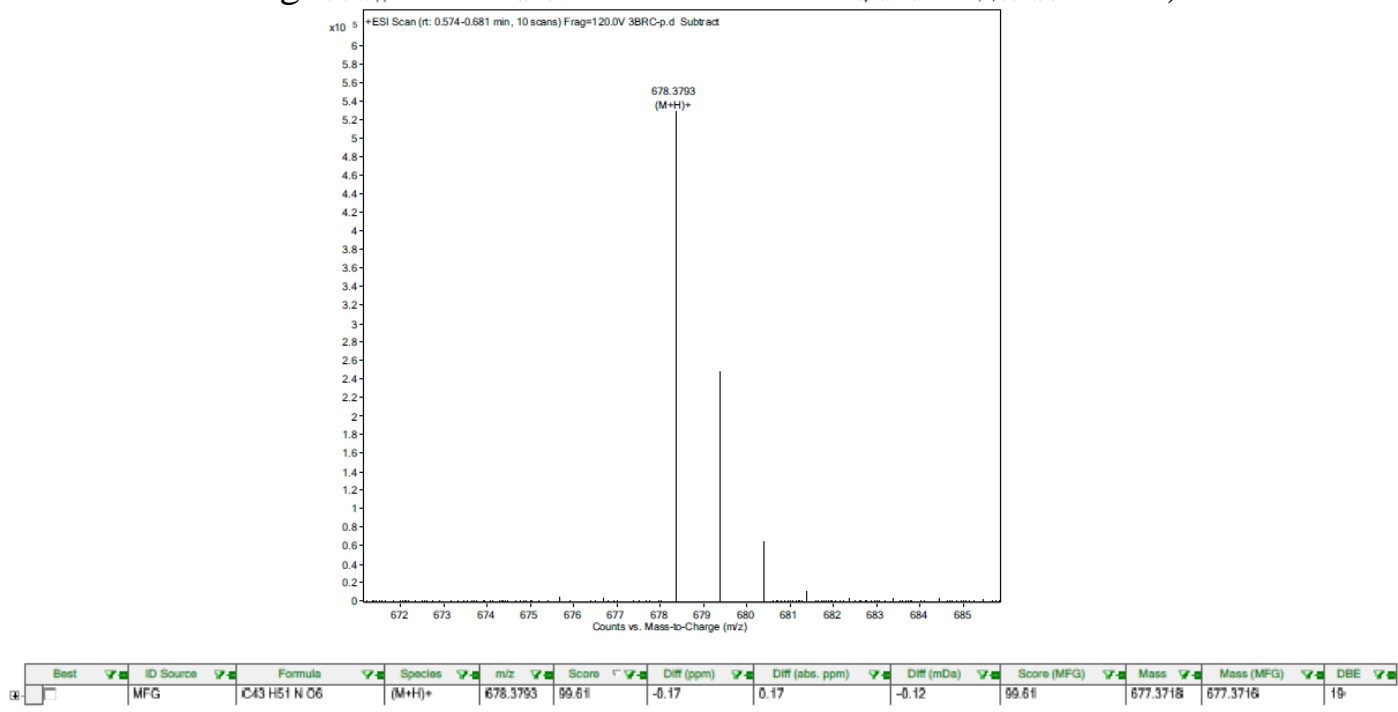

Fig. S105 ESI/HRMS spectrum of $\mathbf{3 5}$ 


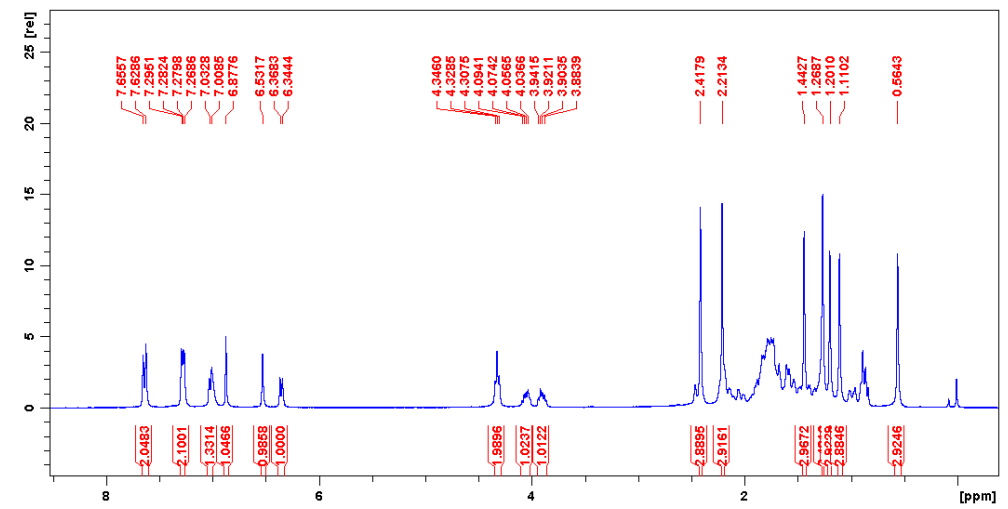

Fig. S106 ${ }^{1} \mathrm{H}$ NMR spectrum of $\mathbf{3 6}\left(300 \mathrm{MHz}\right.$ in $\left.\mathrm{CDCl}_{3}\right)$

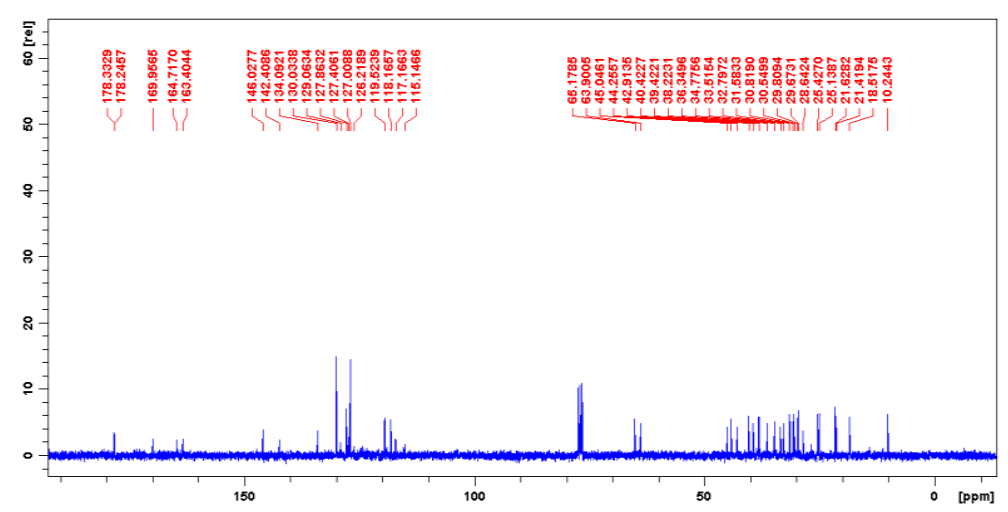

Fig. S107 ${ }^{13} \mathrm{C}$ NMR spectrum of $\mathbf{3 6}\left(75 \mathrm{MHz}\right.$ in $\left.\mathrm{CDCl}_{3}\right)$
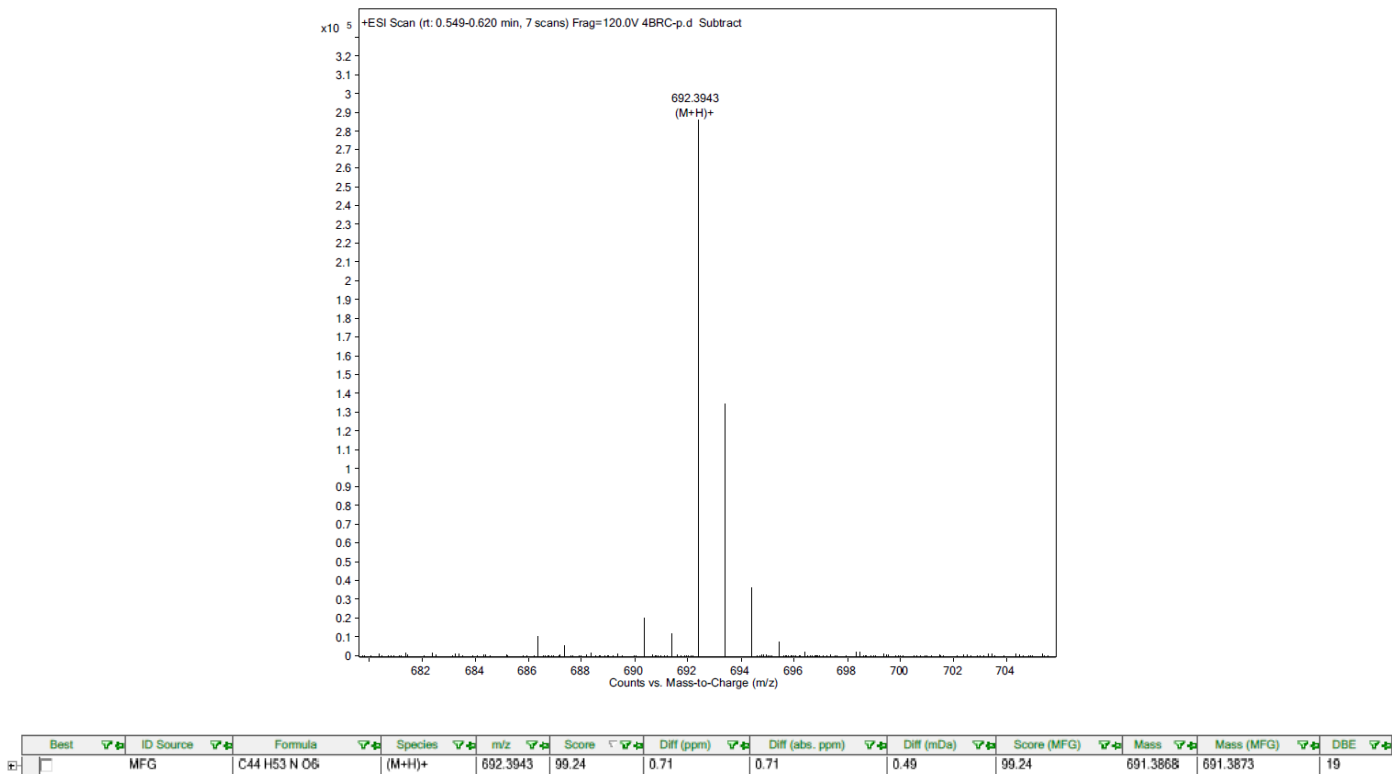

Fig. S108 ESI/HRMS spectrum of $\mathbf{3 6}$ 


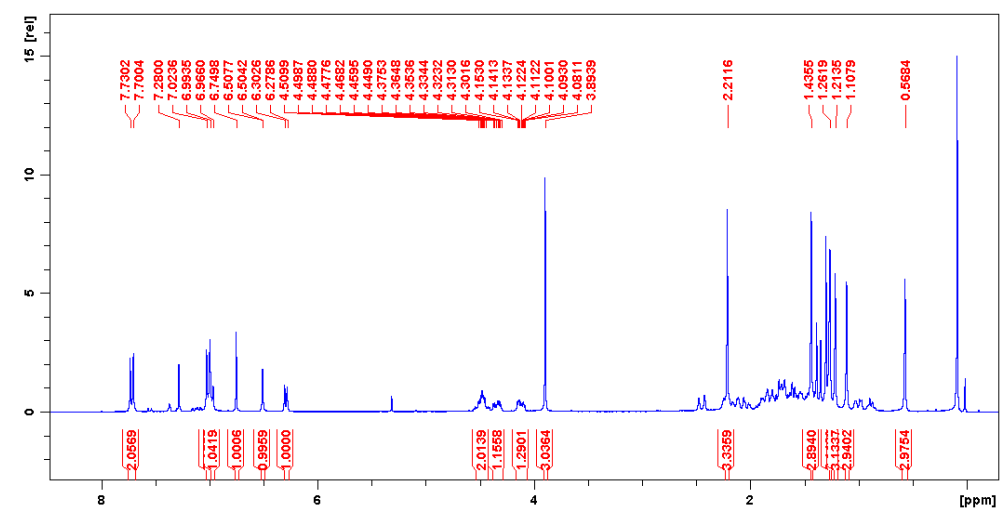

Fig. S109 ${ }^{1} \mathrm{H}$ NMR spectrum of $\mathbf{3 7}\left(300 \mathrm{MHz}\right.$ in $\left.\mathrm{CDCl}_{3}\right)$

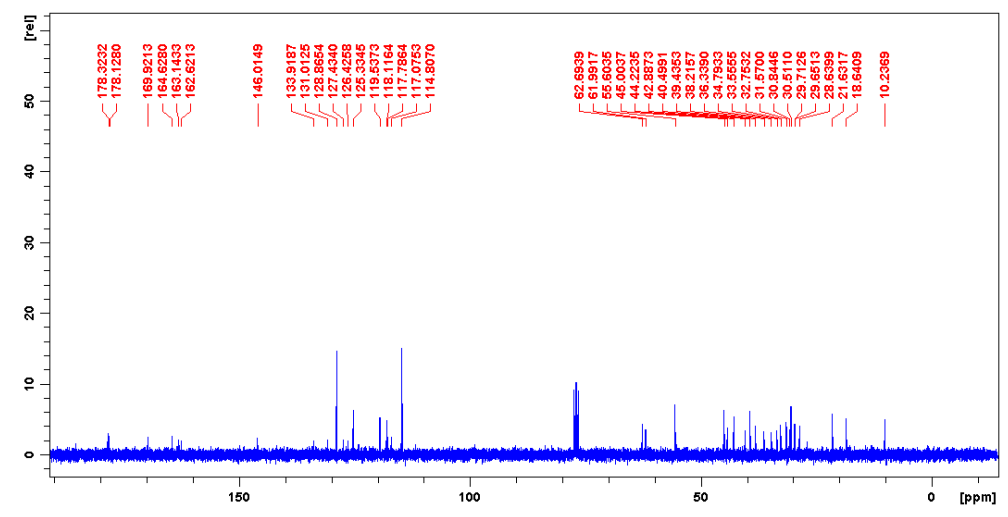

Fig. S110 ${ }^{13} \mathrm{C}$ NMR spectrum of $37\left(75 \mathrm{MHz}\right.$ in $\left.\mathrm{CDCl}_{3}\right)$

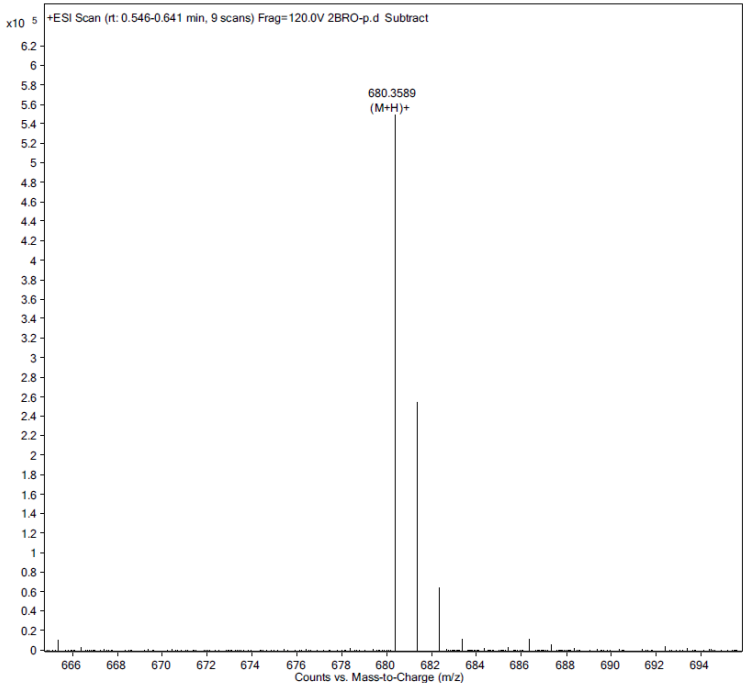

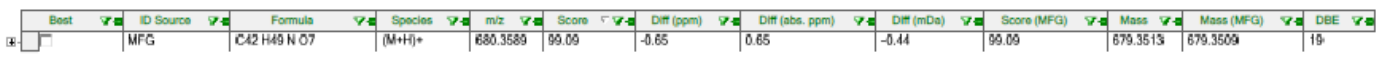

Fig. S111 ESI/HRMS spectrum of $\mathbf{3 7}$ 


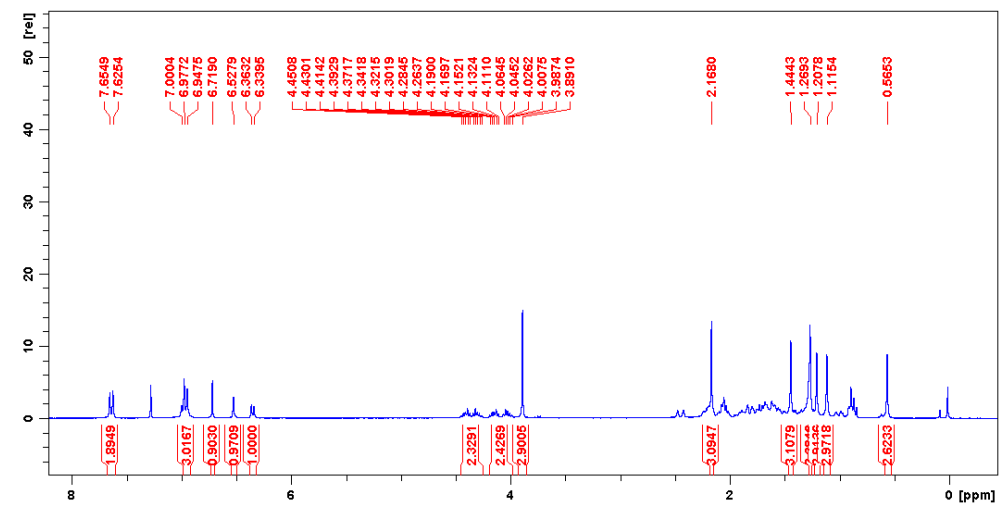

Fig. S112 ${ }^{1} \mathrm{H}$ NMR spectrum of $38\left(300 \mathrm{MHz}\right.$ in $\left.\mathrm{CDCl}_{3}\right)$

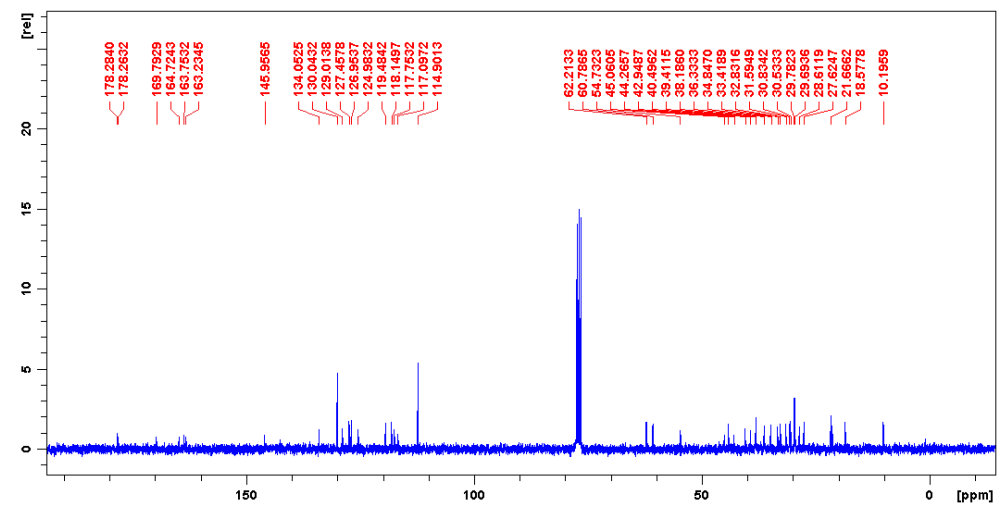

Fig. S113 ${ }^{13} \mathrm{C}$ NMR spectrum of $38\left(75 \mathrm{MHz}\right.$ in $\left.\mathrm{CDCl}_{3}\right)$
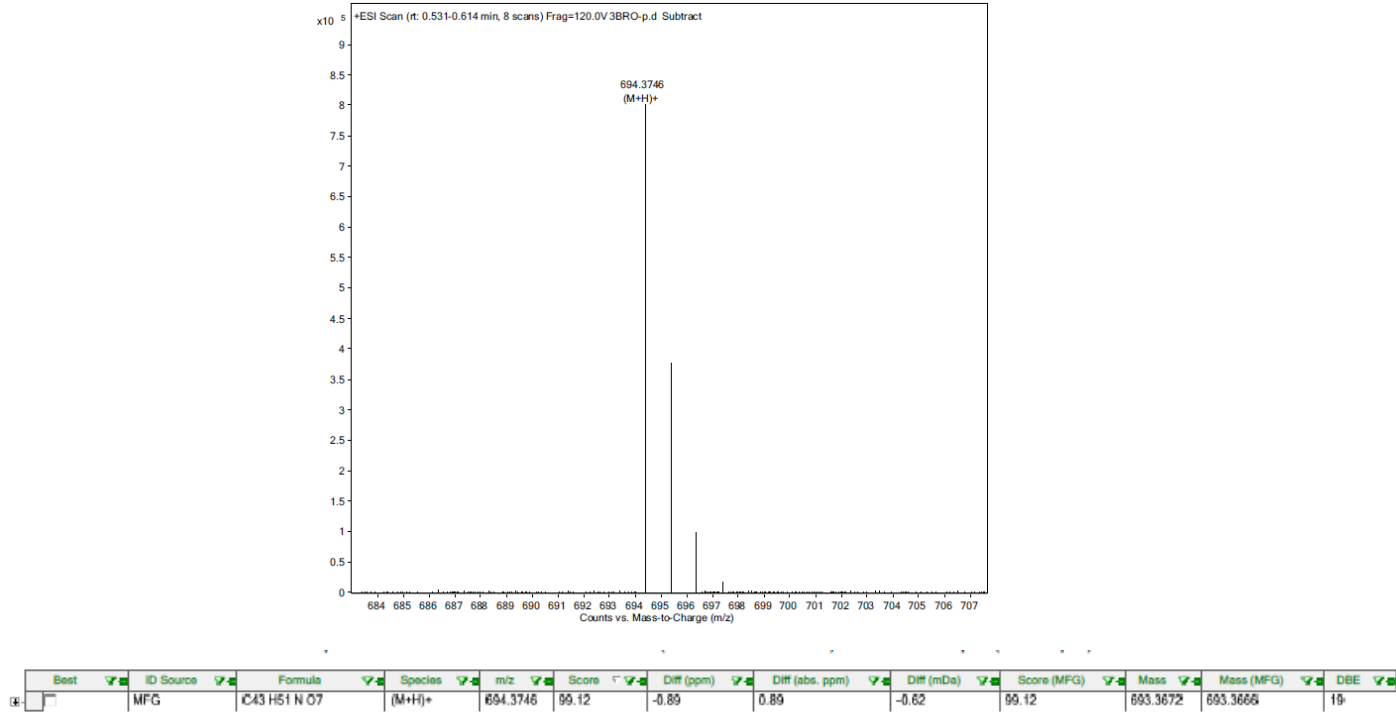

Fig. S114 ESI/HRMS spectrum of $\mathbf{3 8}$ 


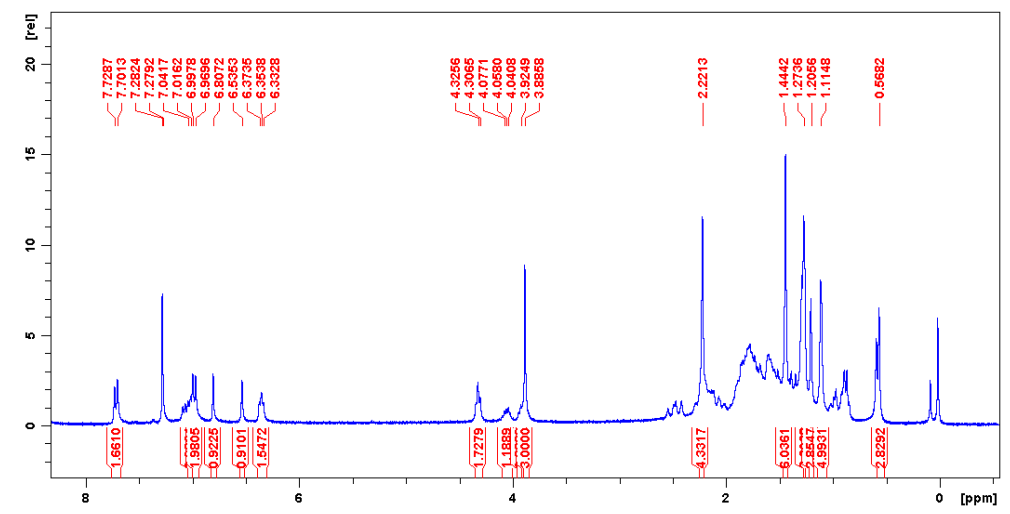

Fig. S115 ${ }^{1} \mathrm{H}$ NMR spectrum of $39\left(300 \mathrm{MHz}\right.$ in $\left.\mathrm{CDCl}_{3}\right)$

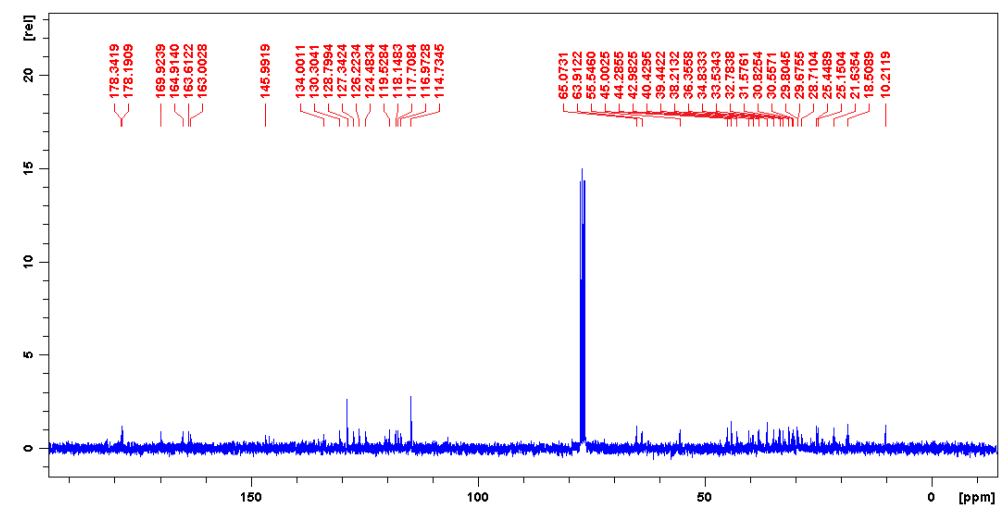

Fig. S116 ${ }^{13} \mathrm{C}$ NMR spectrum of 39 (75 MHz in DMSO- $d_{6}$ )
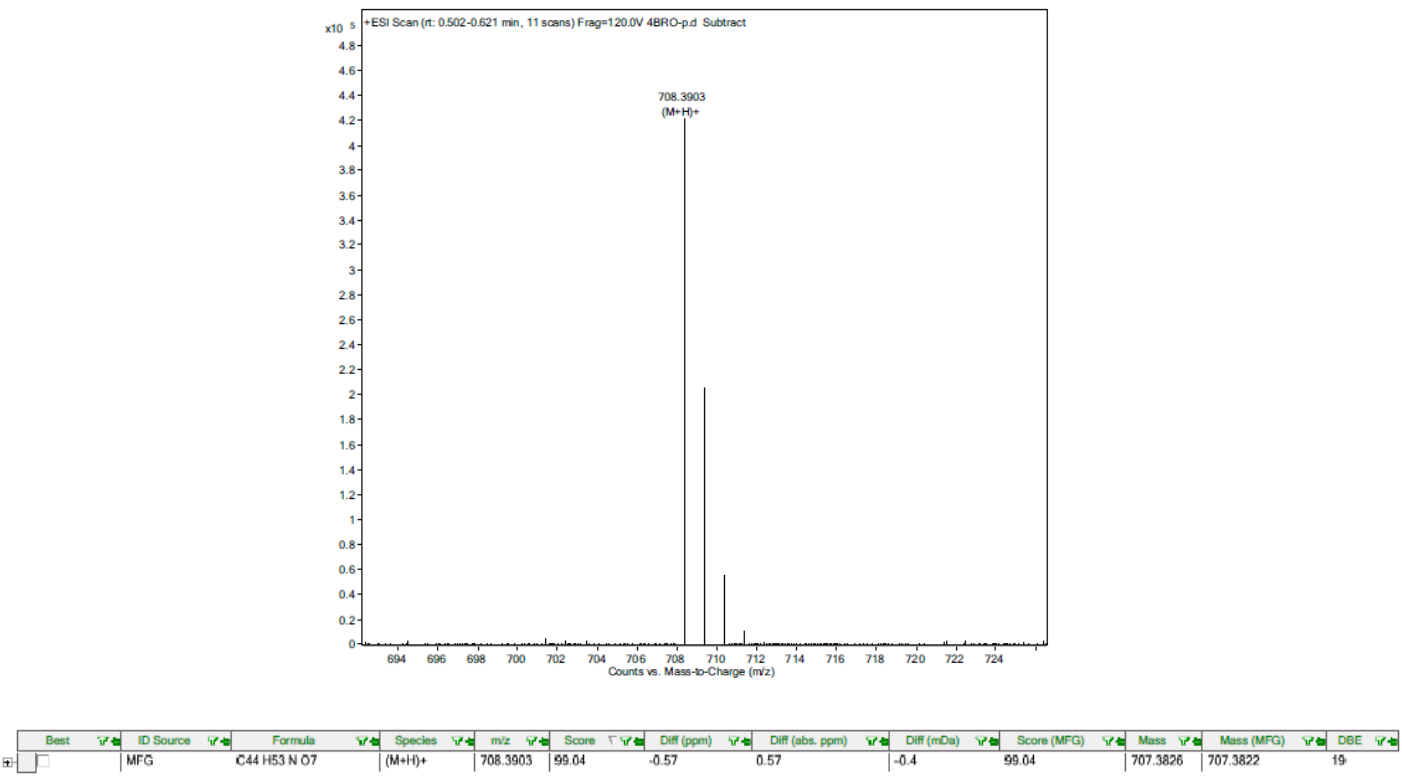

Fig. S117 ESI/HRMS spectrum of 39 


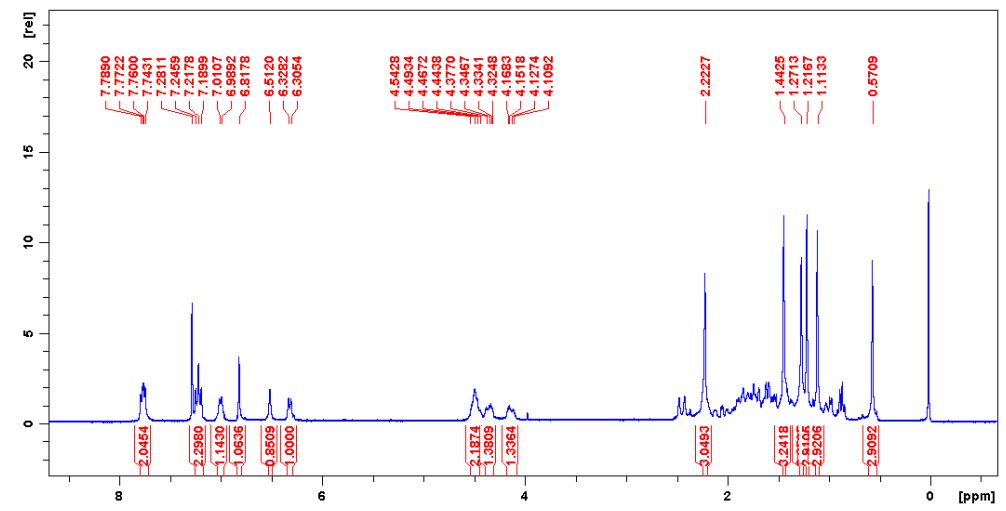

Fig. S118 ${ }^{1} \mathrm{H}$ NMR spectrum of $40\left(300 \mathrm{MHz}\right.$ in $\left.\mathrm{CDCl}_{3}\right)$

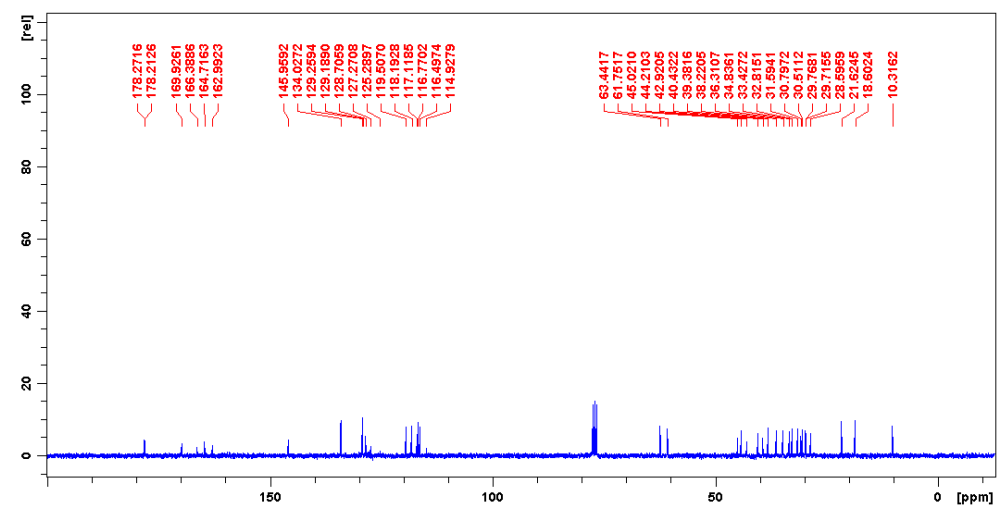

Fig. S119 ${ }^{13} \mathrm{C}$ NMR spectrum of $40\left(75 \mathrm{MHz}\right.$ in $\left.\mathrm{CDCl}_{3}\right)$

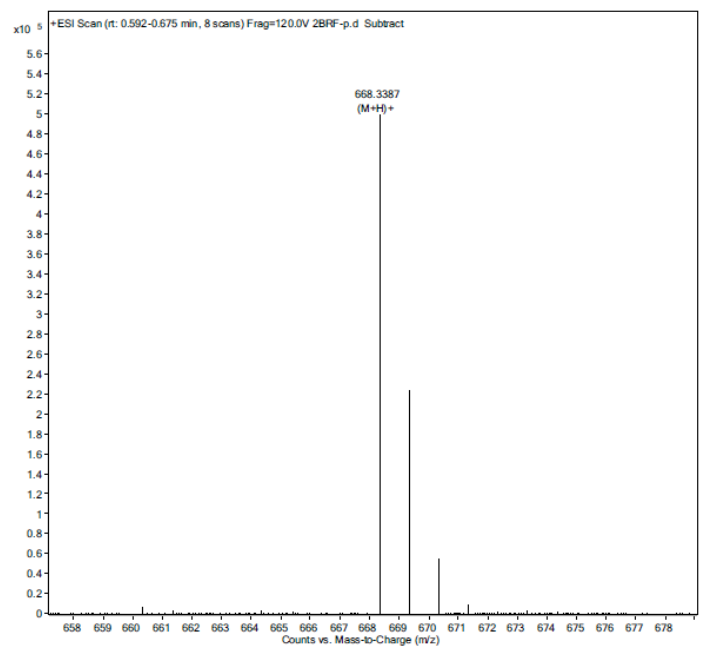

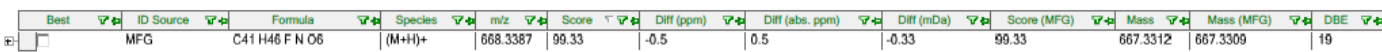

Fig. S120 ESI/HRMS spectrum of $\mathbf{4 0}$ 


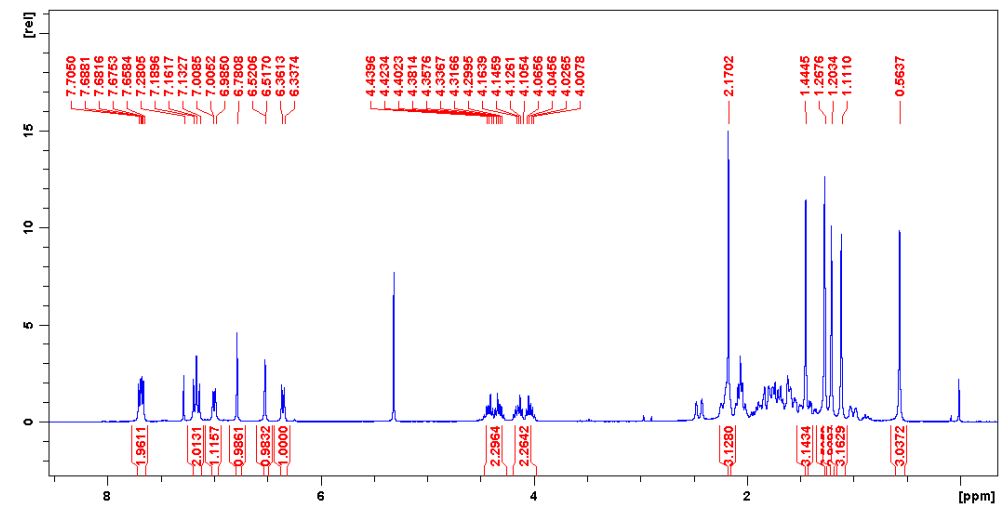

Fig. $\mathrm{S} 121{ }^{1} \mathrm{H}$ NMR spectrum of $41\left(300 \mathrm{MHz}\right.$ in $\left.\mathrm{CDCl}_{3}\right)$

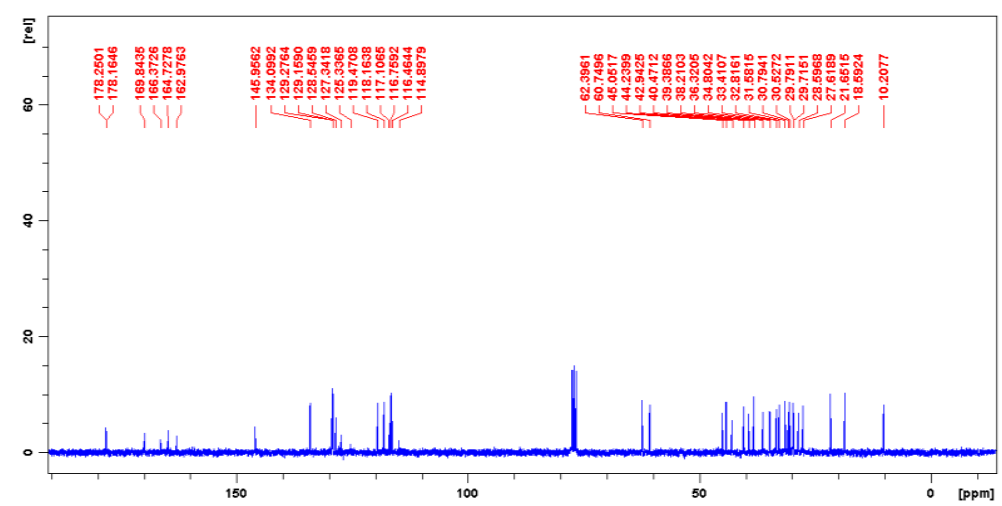

Fig. S122 ${ }^{13} \mathrm{C}$ NMR spectrum of $41\left(75 \mathrm{MHz}\right.$ in $\left.\mathrm{CDCl}_{3}\right)$
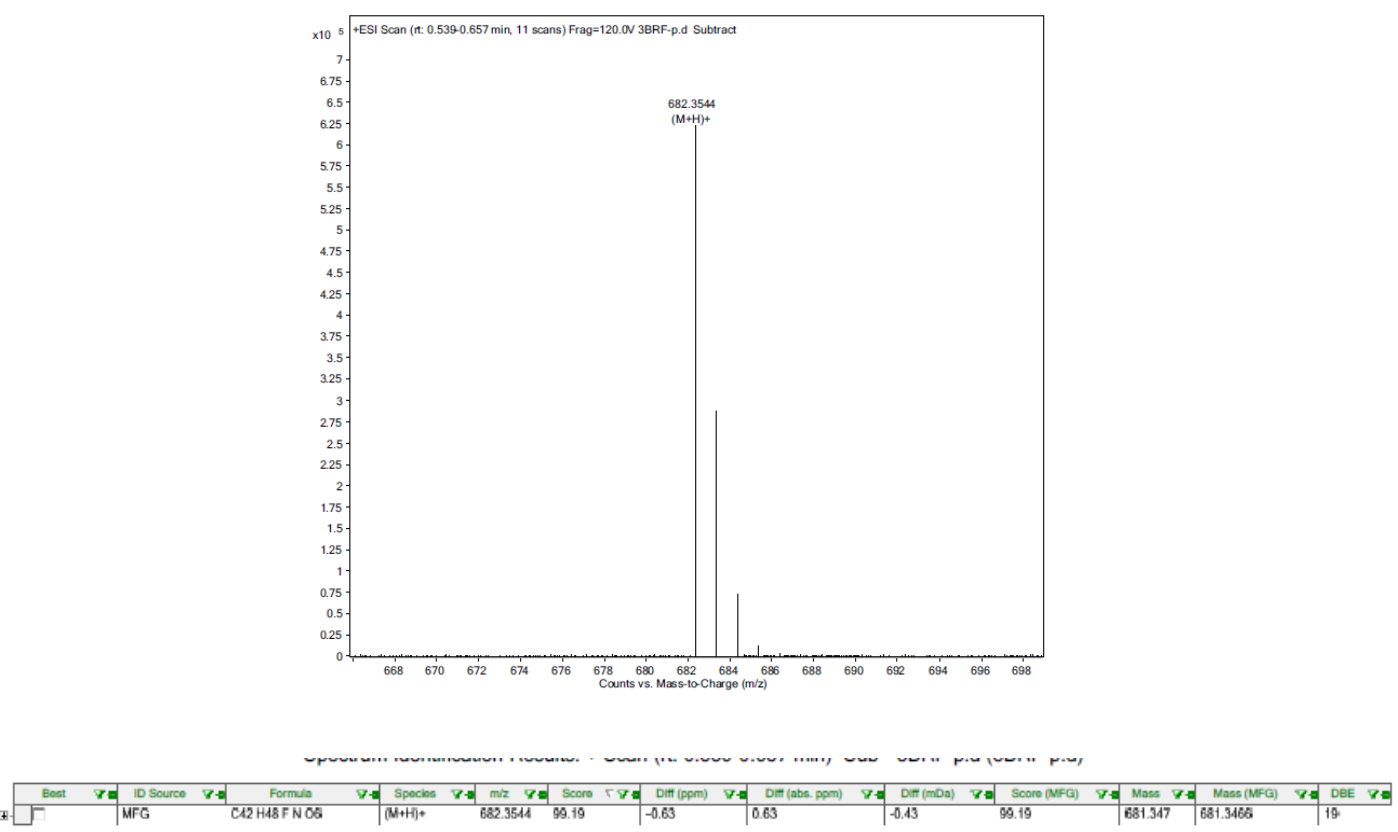

Fig. S123 ESI/HRMS spectrum of 41 


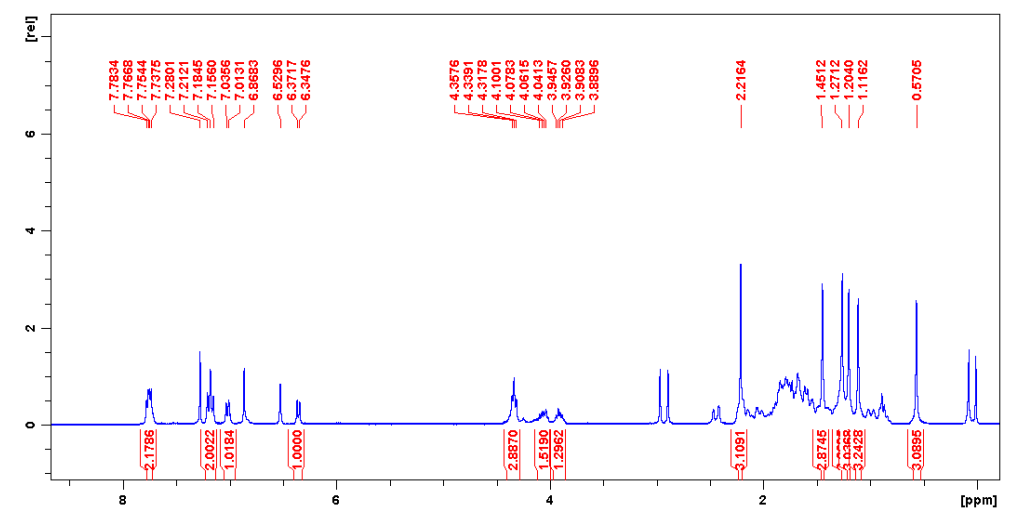

Fig. S124. ${ }^{1} \mathrm{H}$ NMR spectrum of $42\left(300 \mathrm{MHz}\right.$ in $\left.\mathrm{CDCl}_{3}\right)$

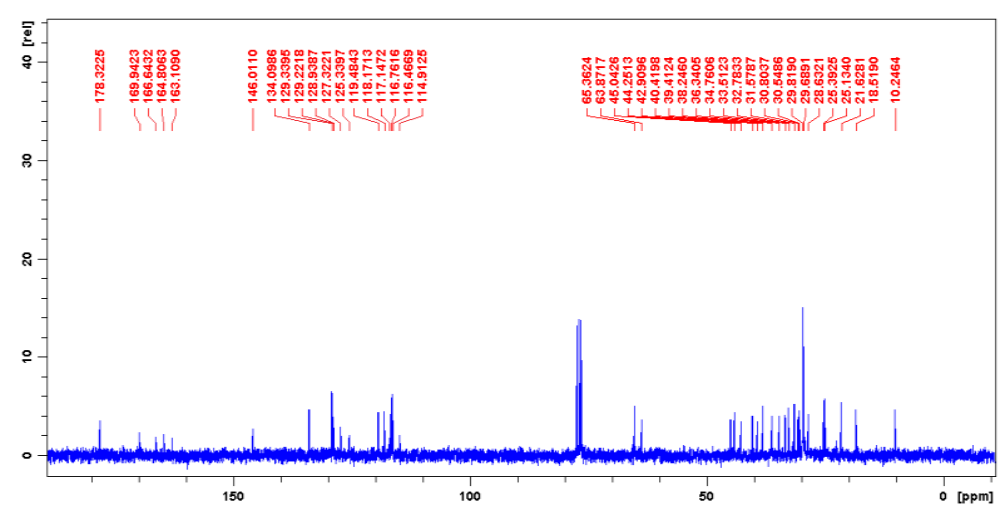

Fig. S125. ${ }^{13} \mathrm{C}$ NMR spectrum of $42\left(75 \mathrm{MHz}\right.$ in $\left.\mathrm{CDCl}_{3}\right)$

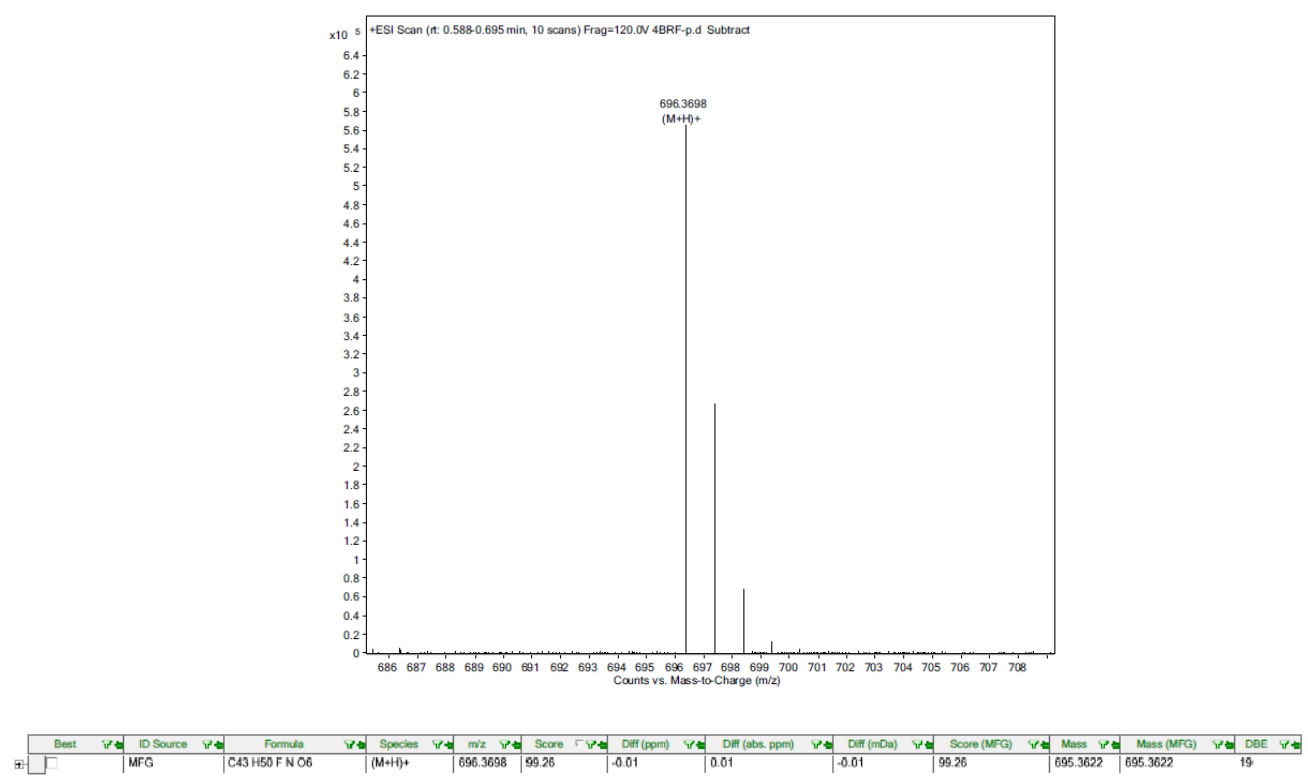

Fig. S126 ESI/HRMS spectrum of $\mathbf{4 2}$ 


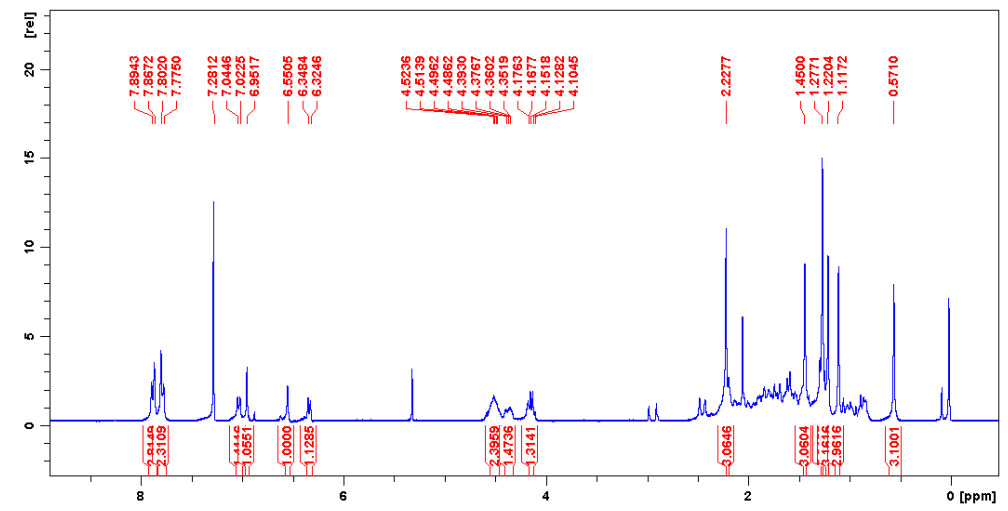

Fig. S127 ${ }^{1} \mathrm{H}$ NMR spectrum of $43\left(300 \mathrm{MHz}\right.$ in $\left.\mathrm{CDCl}_{3}\right)$

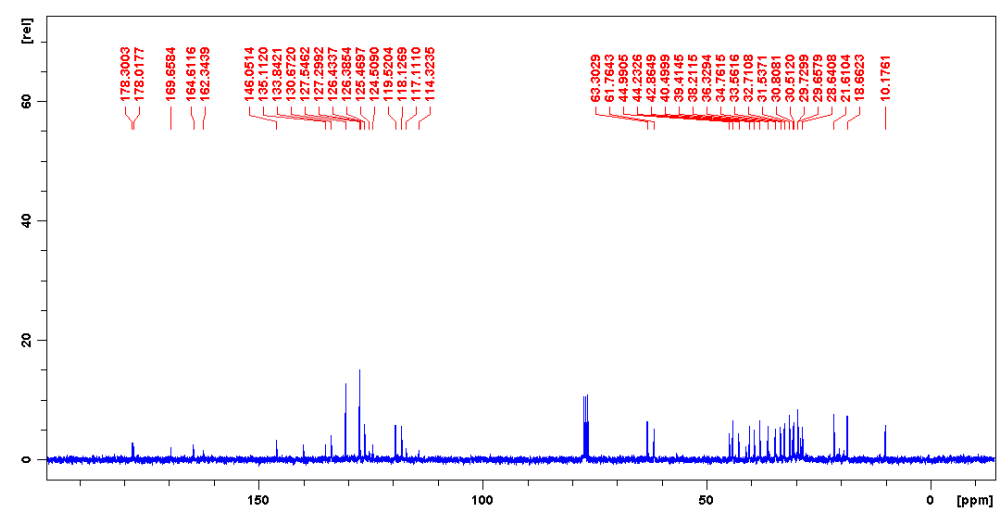

Fig. S128 ${ }^{13} \mathrm{C}$ NMR spectrum of $43\left(75 \mathrm{MHz}\right.$ in $\left.\mathrm{CDCl}_{3}\right)$

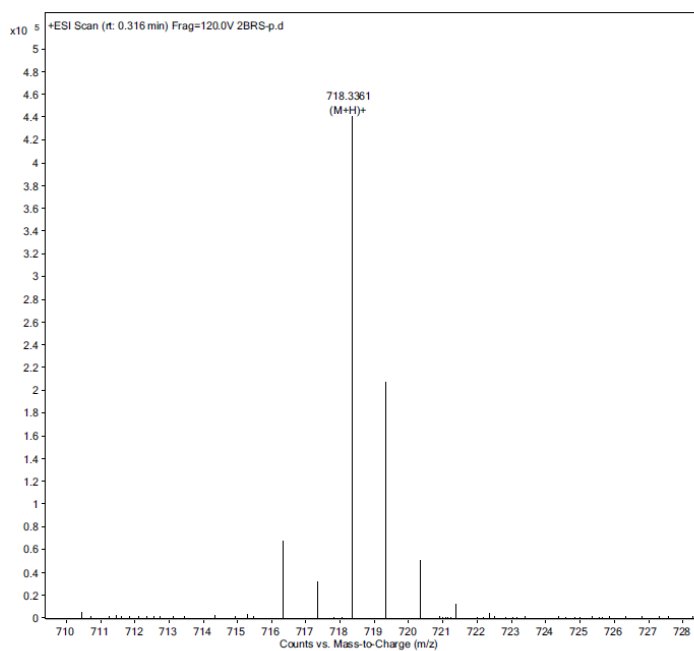

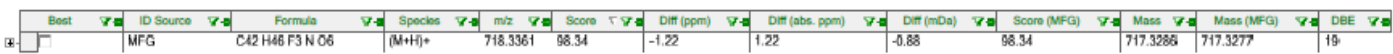

Fig. S129 ESI/HRMS spectrum of $\mathbf{4 3}$ 


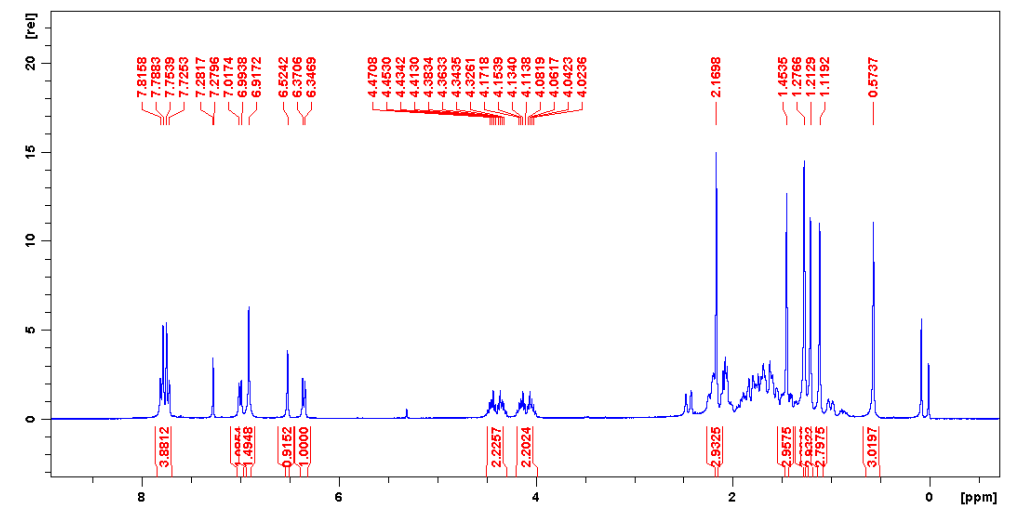

Fig. $\mathrm{S} 130{ }^{1} \mathrm{H}$ NMR spectrum of $44\left(300 \mathrm{MHz}\right.$ in $\left.\mathrm{CDCl}_{3}\right)$

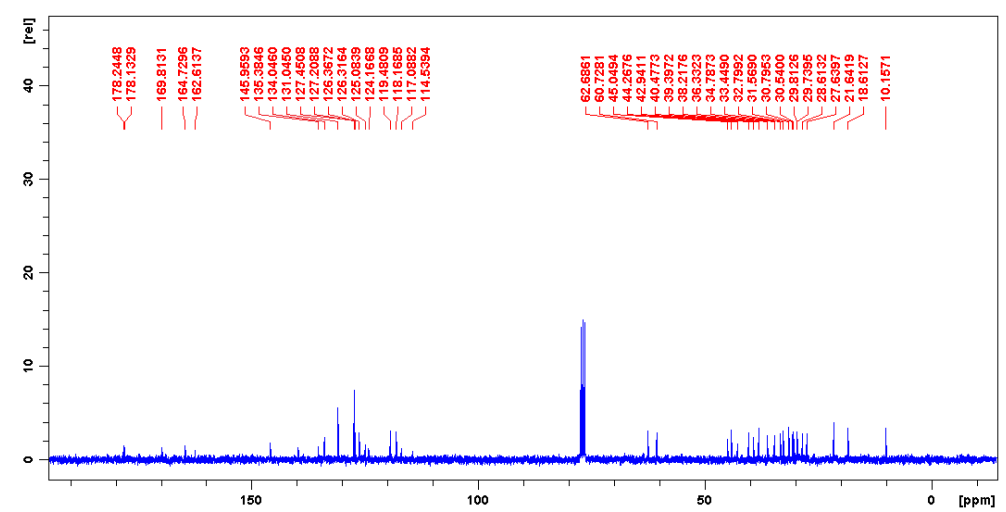

Fig. S131 ${ }^{13} \mathrm{C}$ NMR spectrum of $44\left(75 \mathrm{MHz}\right.$ in $\left.\mathrm{CDCl}_{3}\right)$
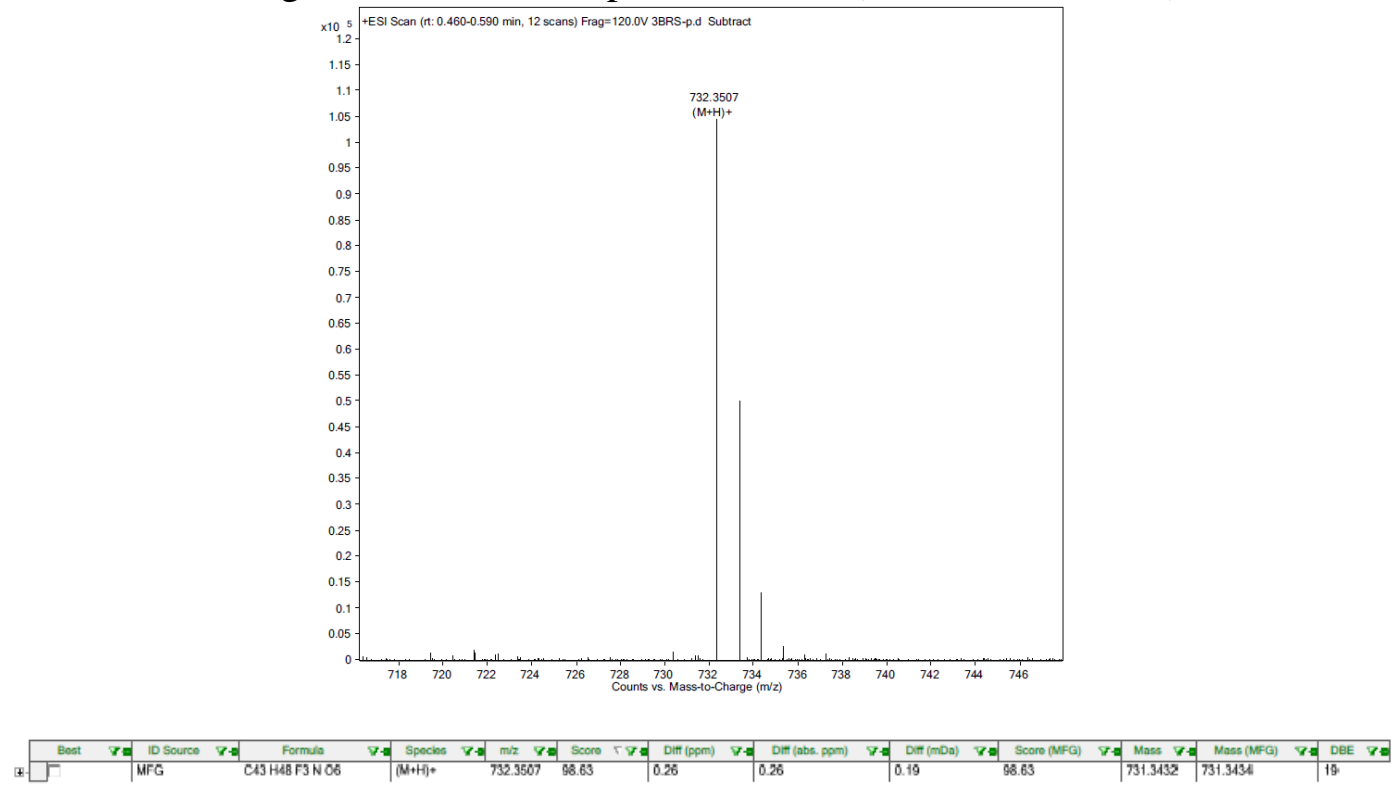

Fig. S132 ESI/HRMS spectrum of $\mathbf{4 4}$ 


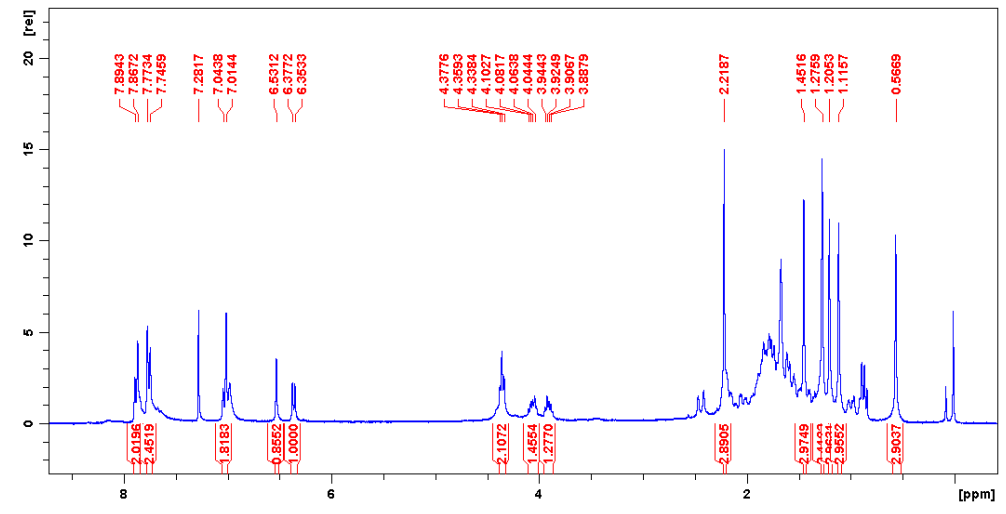

Fig. S133 ${ }^{1} \mathrm{H}$ NMR spectrum of $45\left(300 \mathrm{MHz}\right.$ in $\left.\mathrm{CDCl}_{3}\right)$

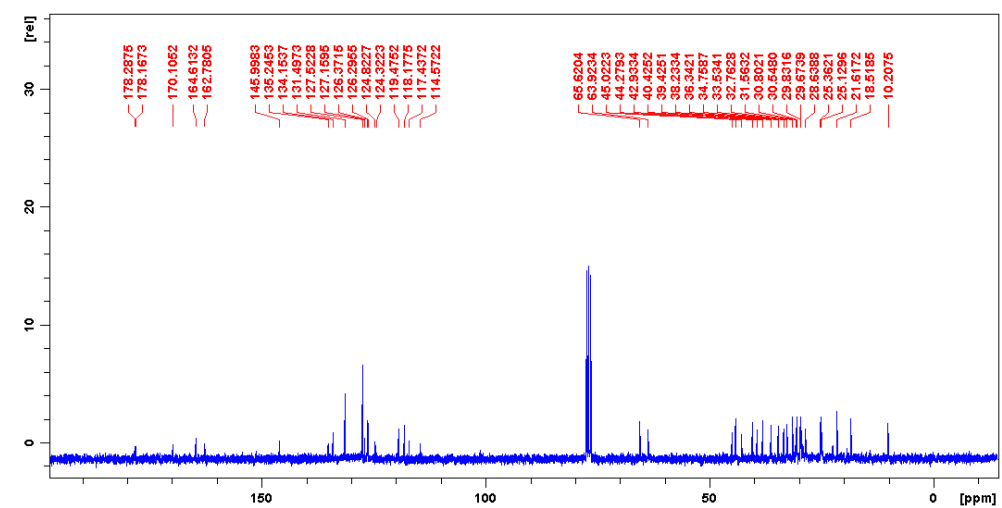

Fig. S134 ${ }^{13} \mathrm{C}$. NMR snectrum of 45 (75 MHz in $\left.\mathrm{CDCl}_{3}\right)$
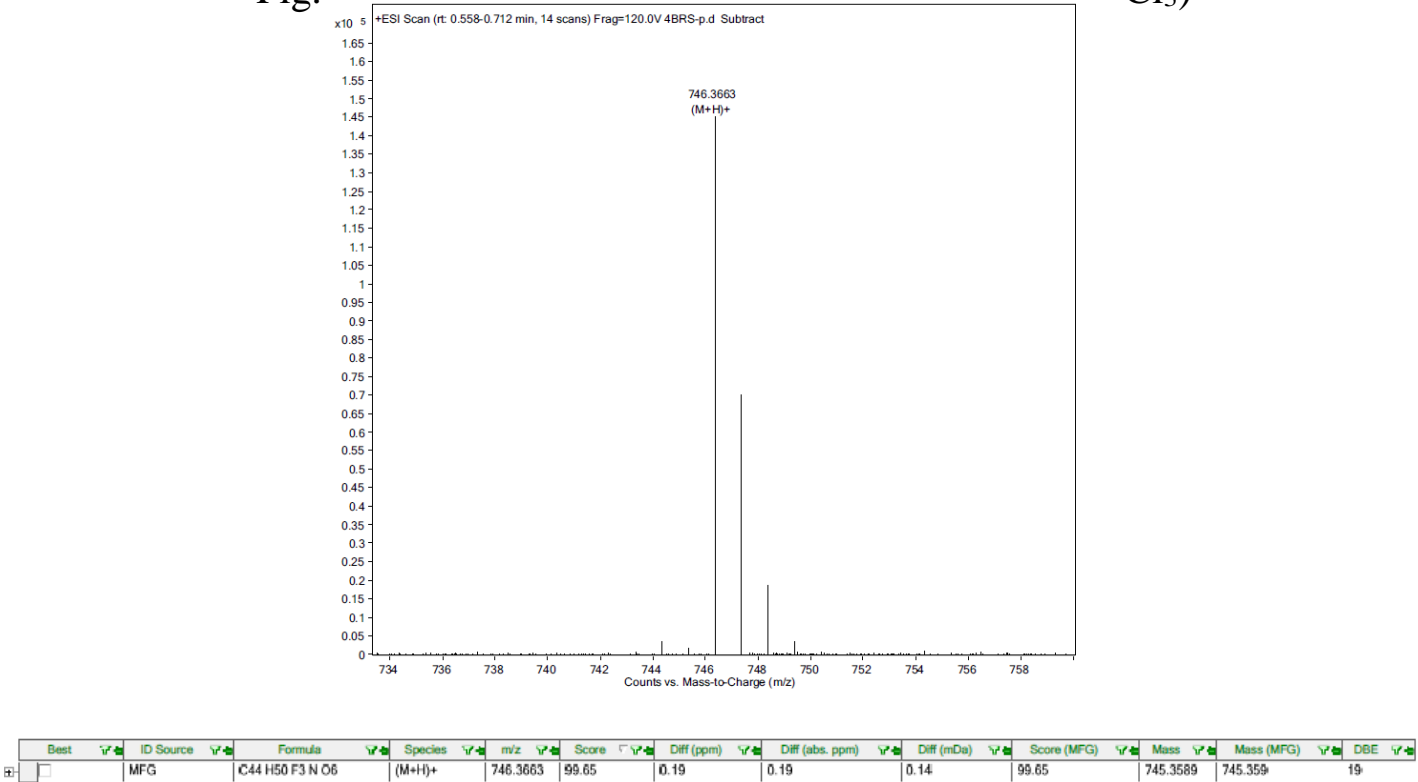

Fig. S135 ESI/HRMS spectrum of $\mathbf{4 5}$ 


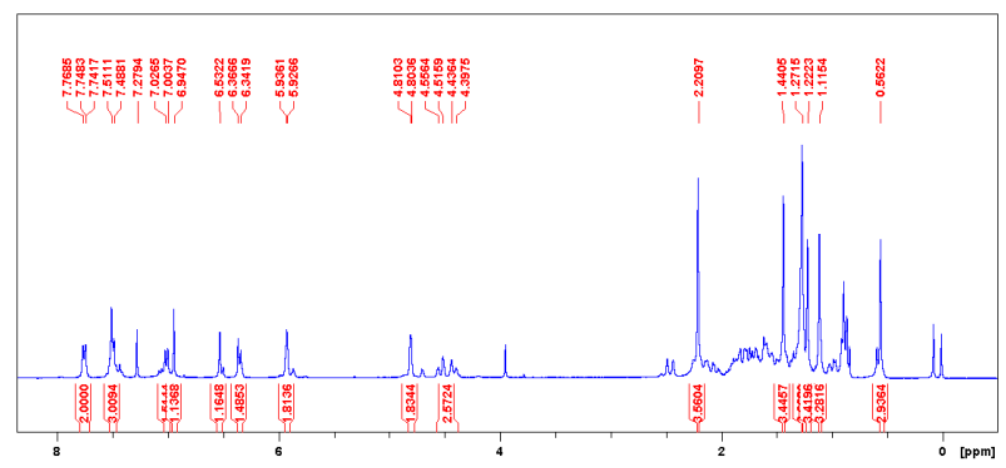

Fig. S136 ${ }^{1} \mathrm{H}$ NMR spectrum of $46\left(300 \mathrm{MHz}\right.$ in $\left.\mathrm{CDCl}_{3}\right)$

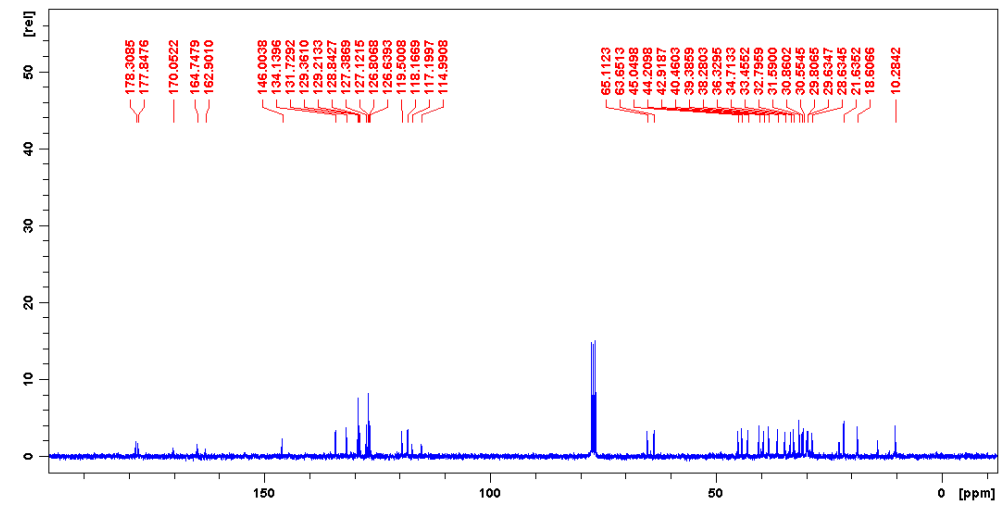

Fig. $\mathrm{S} 137{ }^{13} \mathrm{C}$ NMR spectrum of $46\left(75 \mathrm{MHz}\right.$ in $\left.\mathrm{CDCl}_{3}\right)$
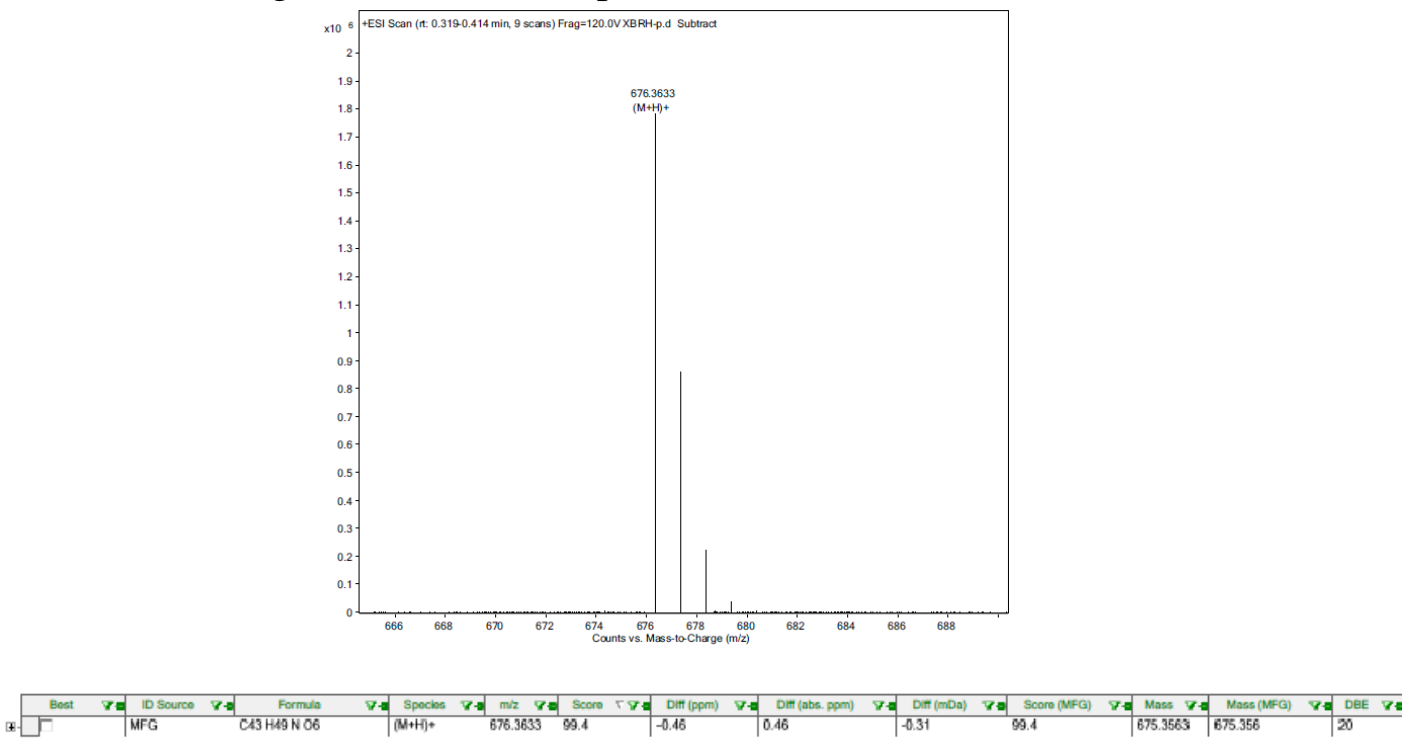

Fig. S138 ESI/HRMS spectrum of $\mathbf{4 6}$ 


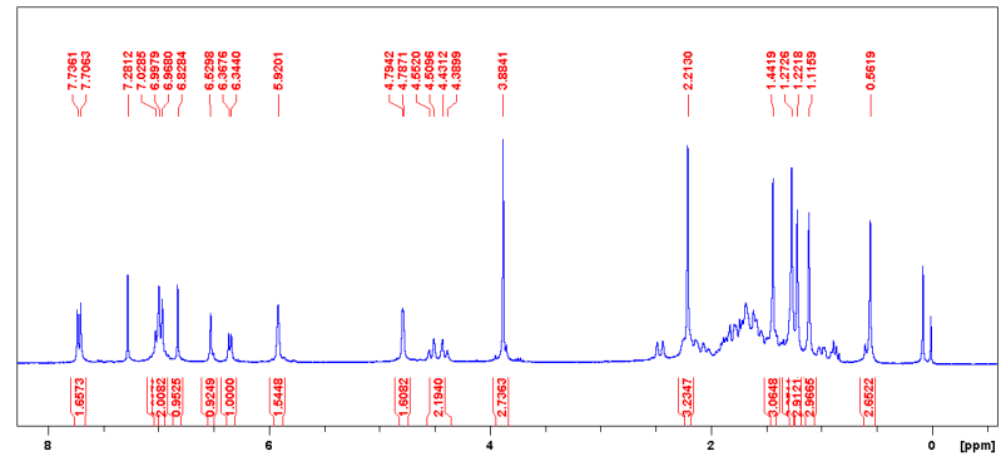

Fig. S139 ${ }^{1} \mathrm{H}$ NMR spectrum of $47\left(300 \mathrm{MHz}\right.$ in $\left.\mathrm{CDCl}_{3}\right)$

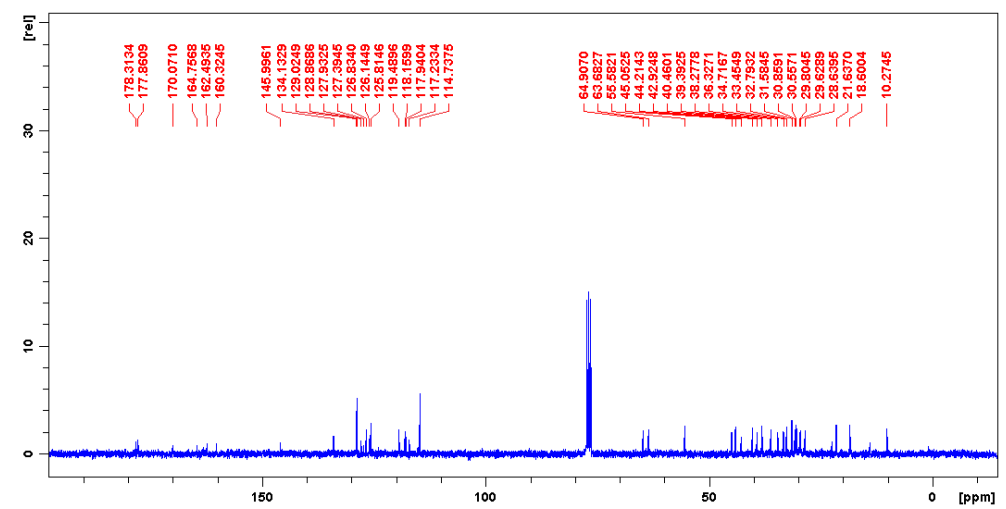

Fig. $\mathrm{S} 140{ }^{13} \mathrm{C}$ NMR spectrum of $47\left(75 \mathrm{MHz}\right.$ in $\left.\mathrm{CDCl}_{3}\right)$
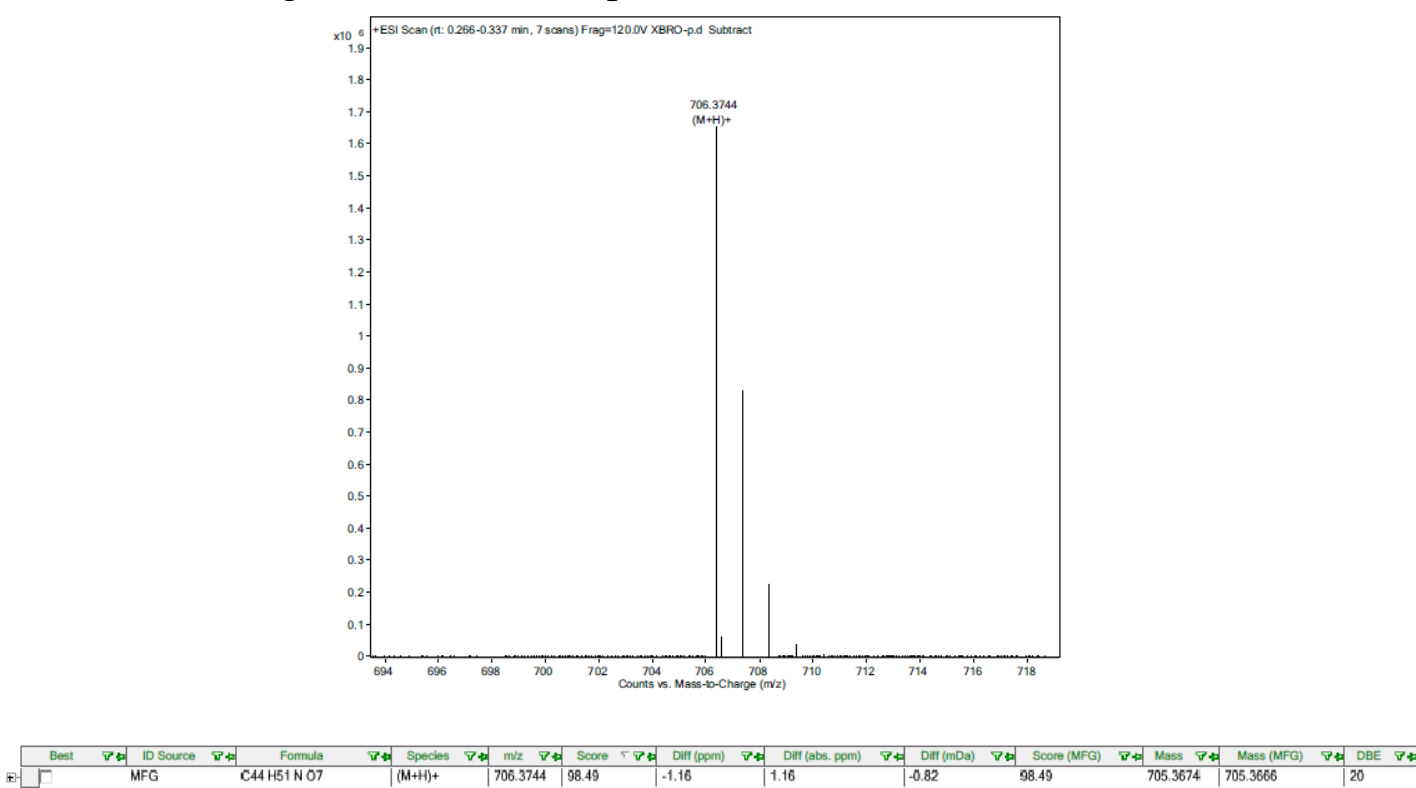

Fig. S141 ESI/HRMS spectrum of $\mathbf{4 7}$ 


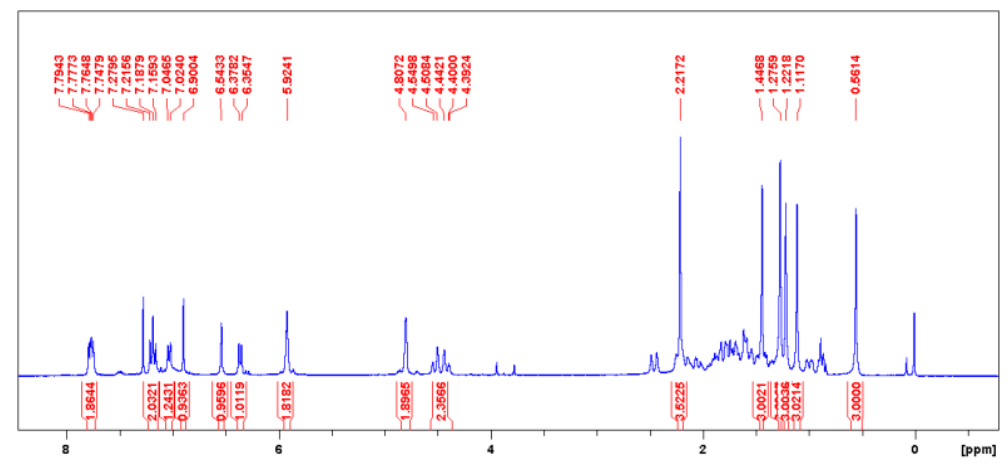

Fig. $\mathrm{S} 142{ }^{1} \mathrm{H}$ NMR spectrum of $48\left(300 \mathrm{MHz}\right.$ in $\left.\mathrm{CDCl}_{3}\right)$

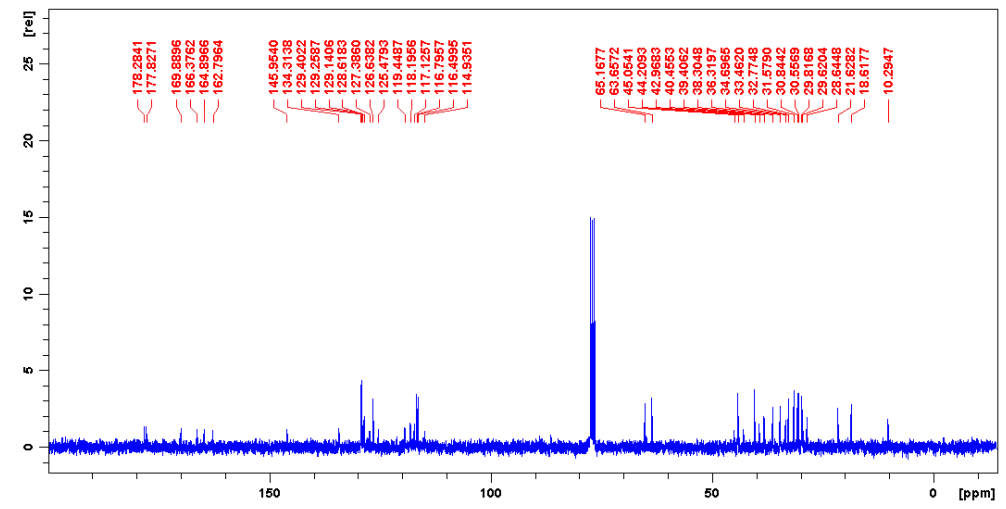

Fig. $\mathrm{S} 143{ }^{13} \mathrm{C}$ NMR spectrum of $48\left(75 \mathrm{MHz}\right.$ in $\left.\mathrm{CDCl}_{3}\right)$
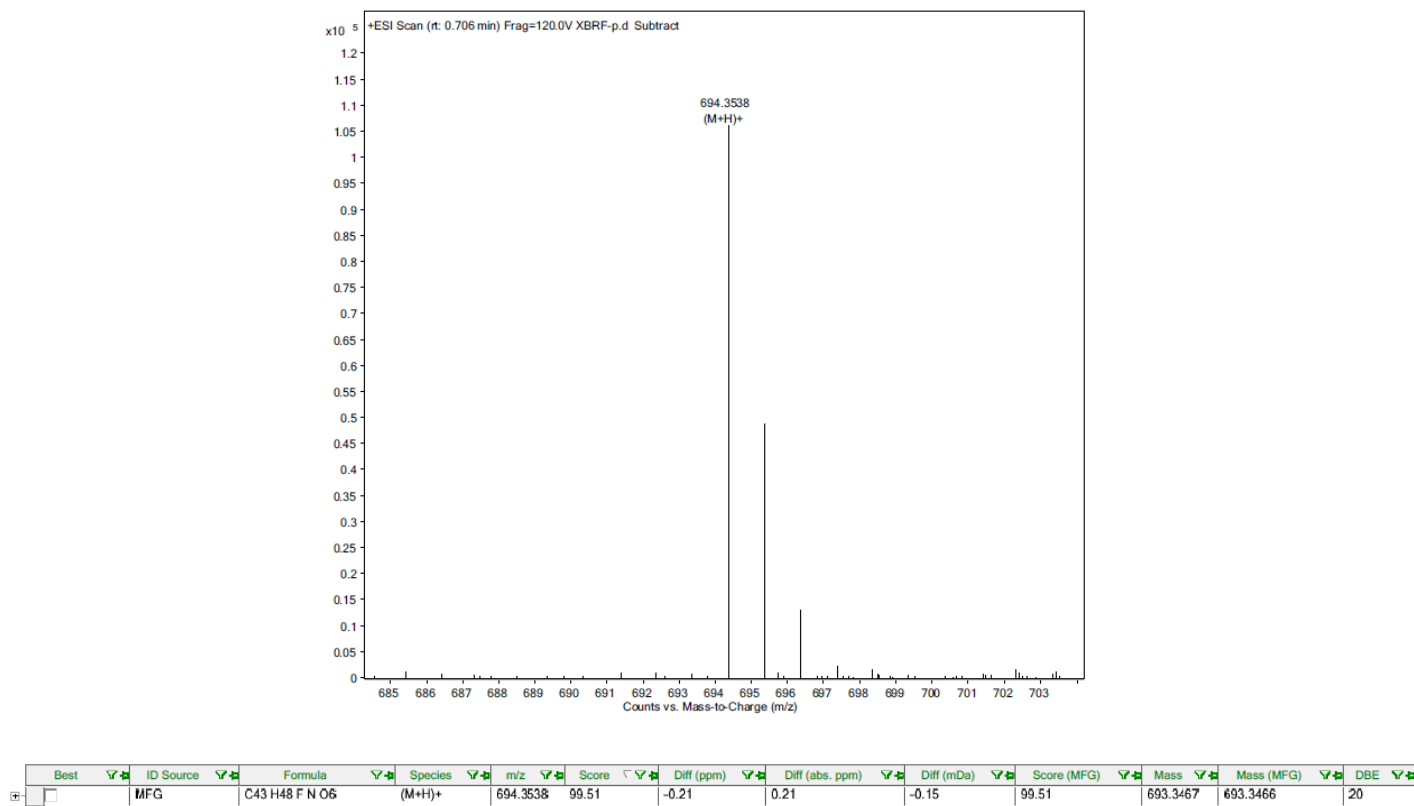

Fig. S144 ESI/HRMS spectrum of $\mathbf{4 8}$ 

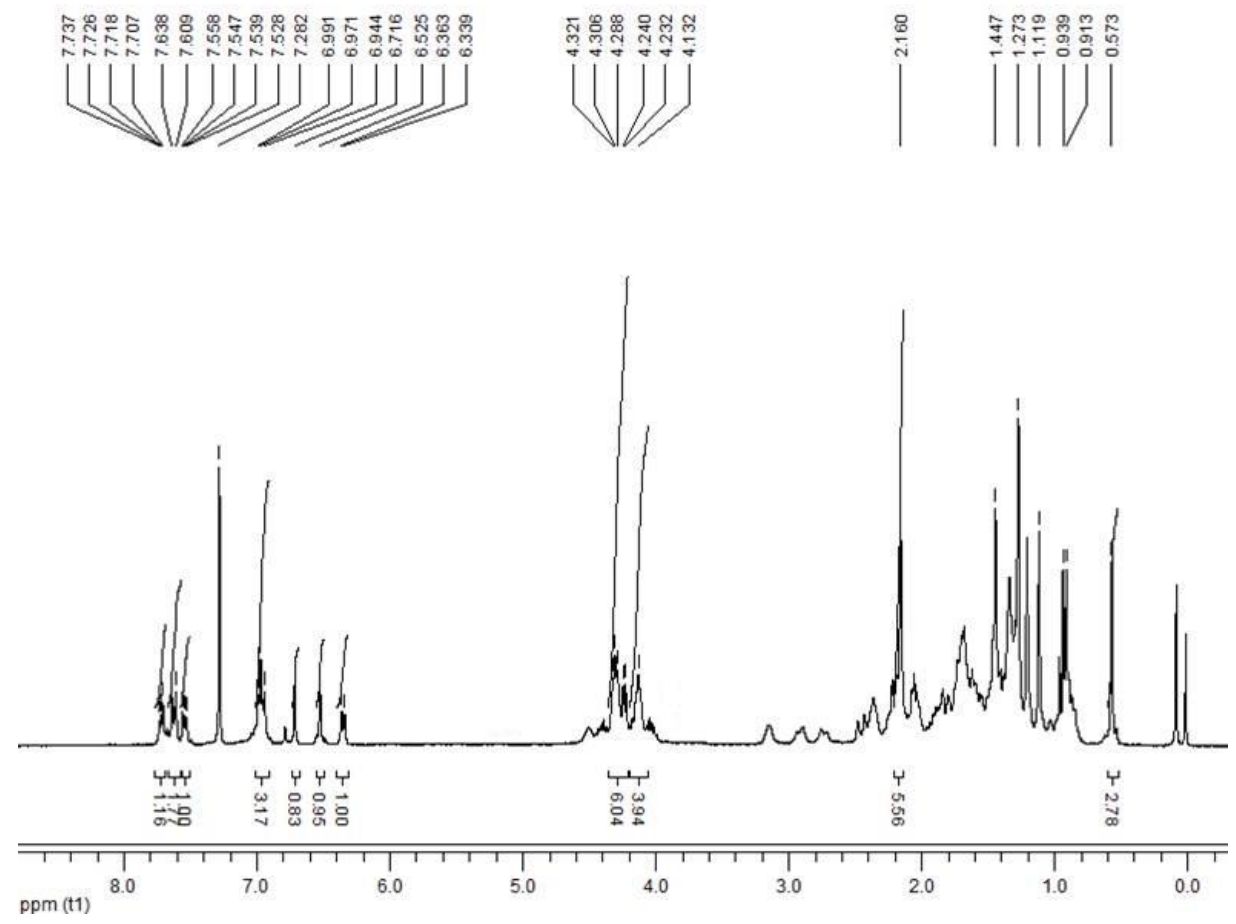

Fig. S145 ${ }^{1} \mathrm{H}$ NMR spectrum of 41-Bio $\left(300 \mathrm{MHz}\right.$ in $\left.\mathrm{CDCl}_{3}\right)$
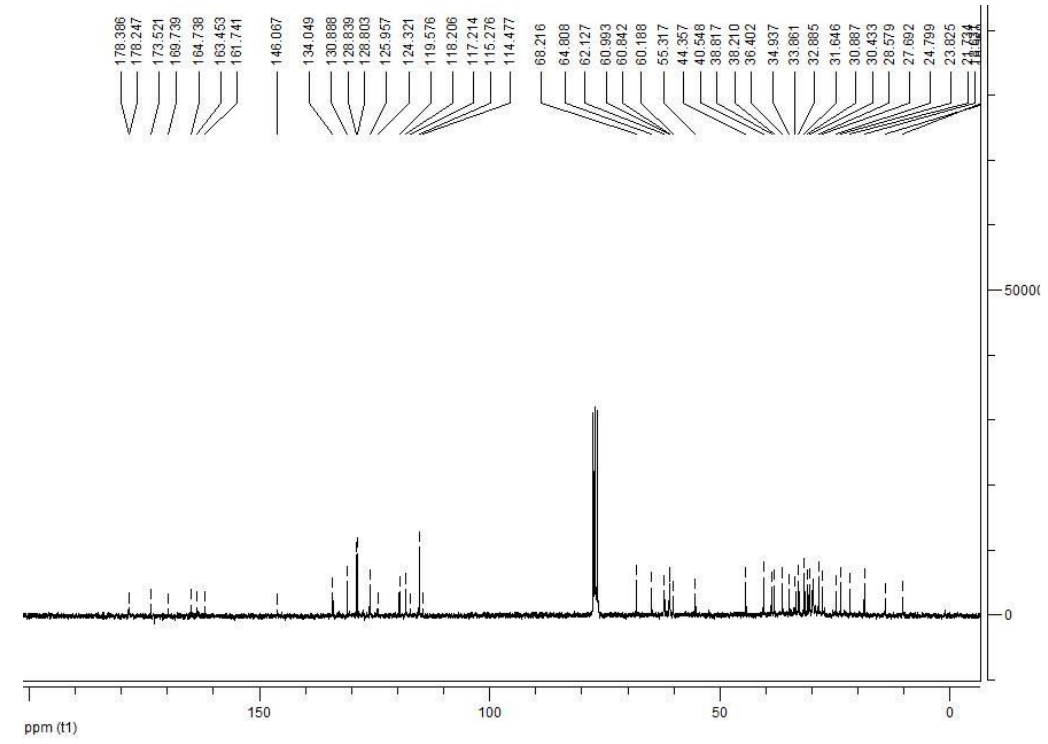

Fig. S146 ${ }^{13} \mathrm{C}$ NMR spectrum of 41-Bio $\left(75 \mathrm{MHz}\right.$ in $\left.\mathrm{CDCl}_{3}\right)$ 


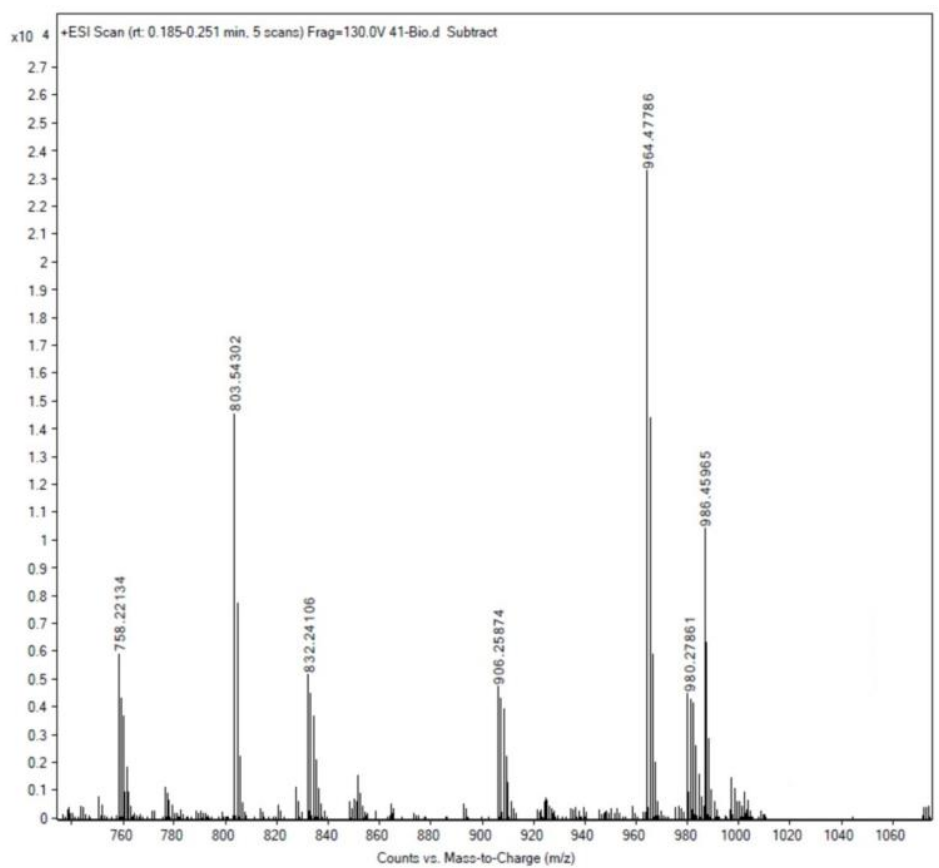

Fig. S144 ESI/HRMS spectrum of 41-Bio

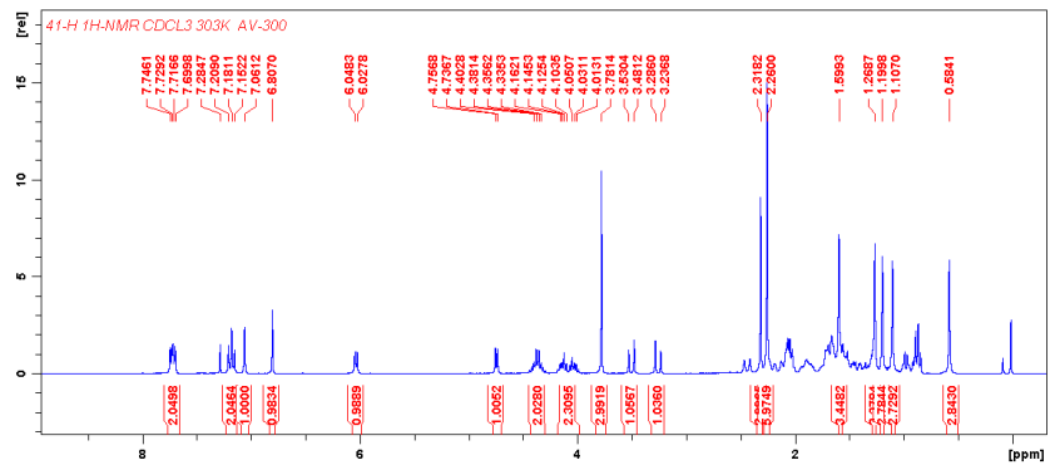

Fig. S145 ${ }^{1} \mathrm{H}$ NMR spectrum of $\mathbf{4 1 - H}$

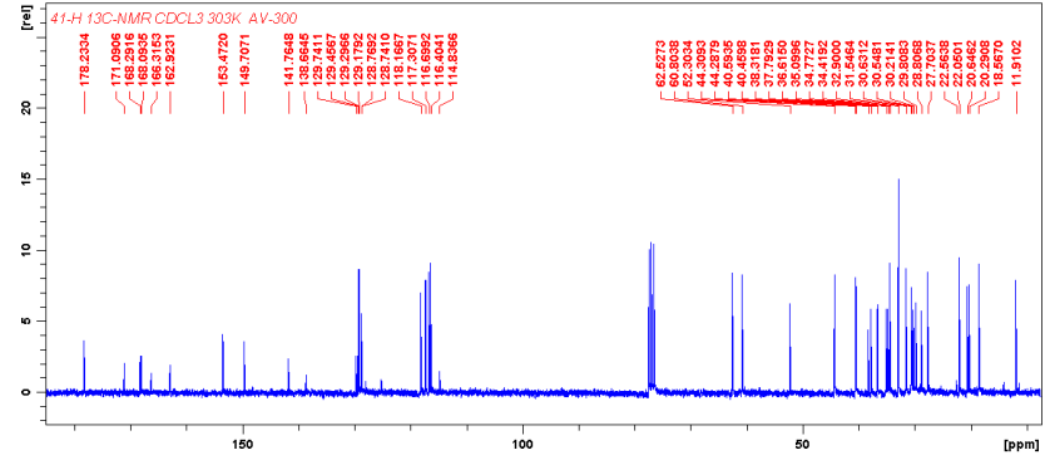

Fig. S146 ${ }^{13} \mathrm{C}$ NMR spectrum of $\mathbf{4 1 - H}\left(75 \mathrm{MHz}\right.$ in $\left.\mathrm{CDCl}_{3}\right)$ 


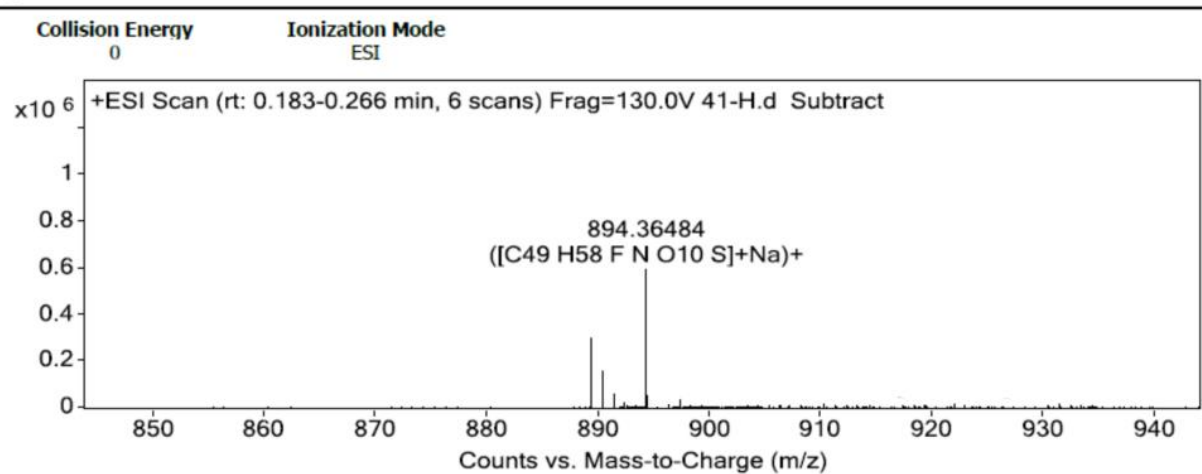

Fig. S147 ESI/HRMS spectrum of 41-H

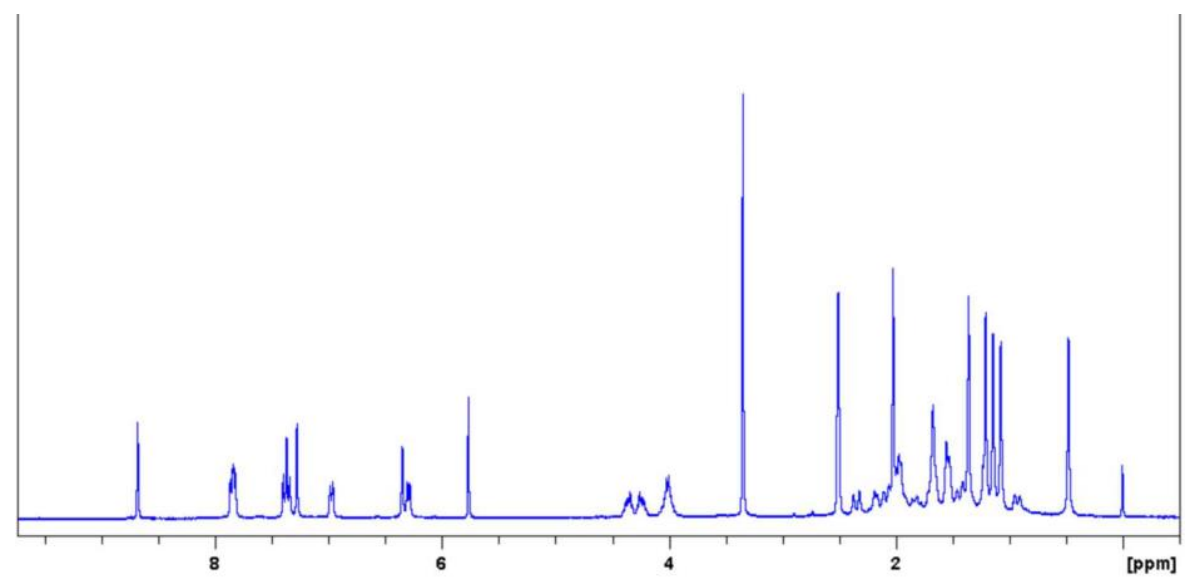

Fig. S148 ${ }^{1} \mathrm{H}$ NMR spectrum of 41 (75 MHz in DMSO-d $)$

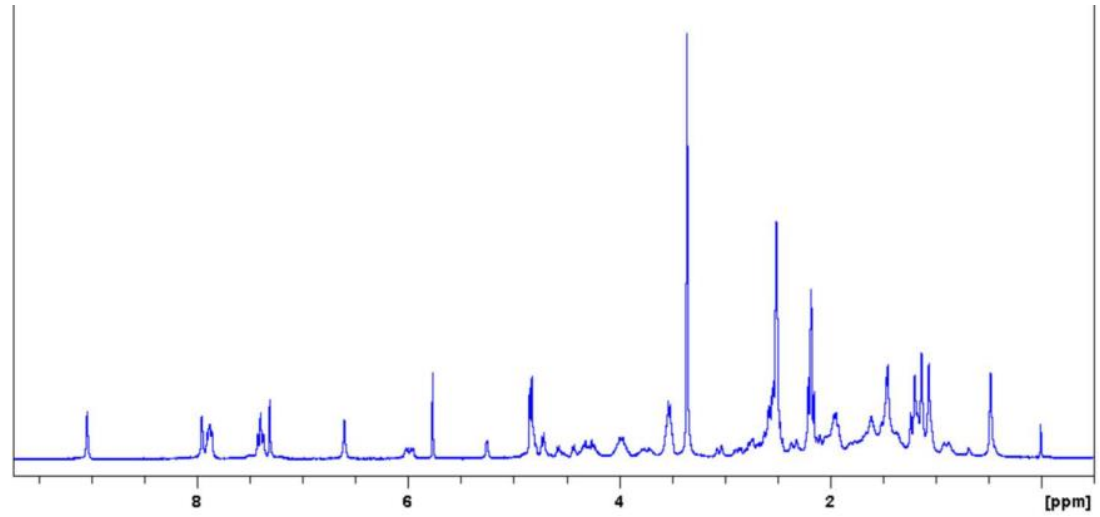

Fig. S149 ${ }^{1} \mathrm{H}$ NMR spectrum of 41 with DTT (75 MHz in DMSO- $d_{6}$ )

2. The synthetic route of compound $\mathbf{4 1 - H}$

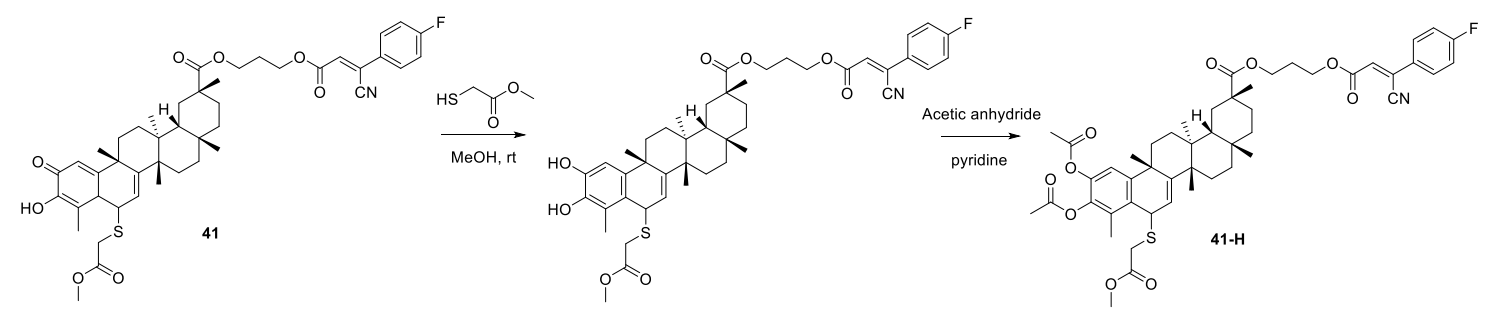


Scheme S1. Reagents and Conditions: (a) sulfhydryl group, $\mathrm{MeOH}$, rt, 15 min; (b) Acetic anhydride, pyridine, $\mathrm{rt}, 12 \mathrm{~h}$.

3. HPLC analysis of target compounds

1) HPLC analysis of compounds $\mathbf{1 - 1 5}(0.8 \mathrm{ml} / \mathrm{min}, 97 \% \mathrm{MeOH})$
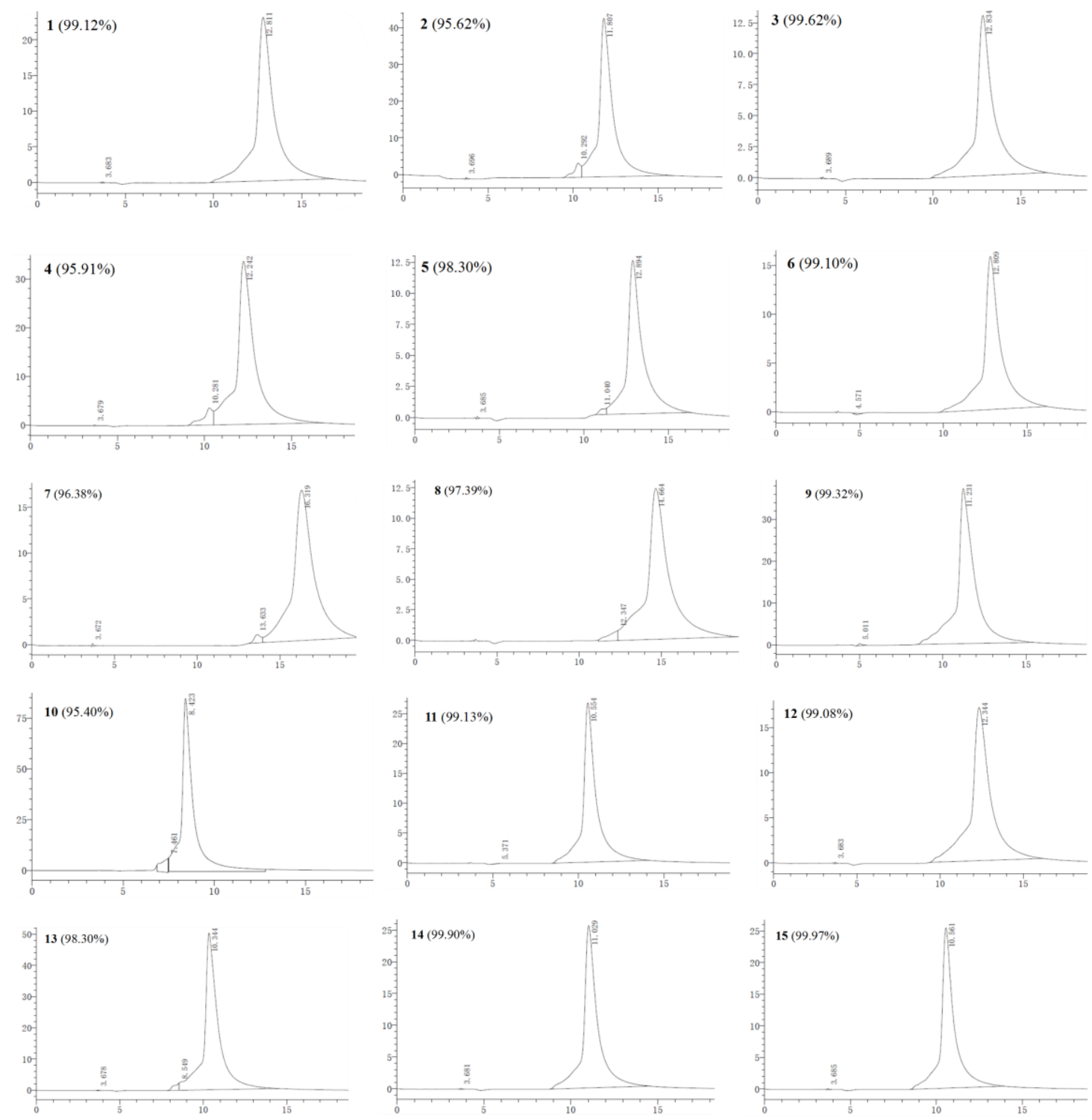

2) HPLC analysis of compounds $\mathbf{1 6 - 4 8}(0.8 \mathrm{ml} / \mathrm{min}, 94 \% \mathrm{MeOH})$
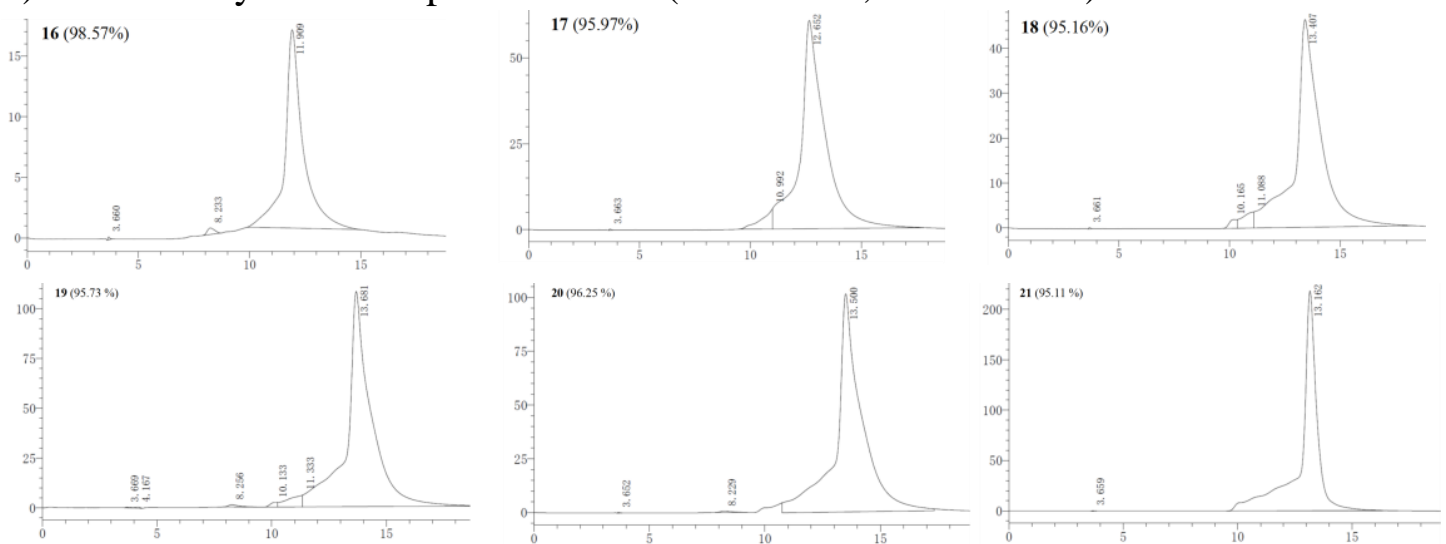

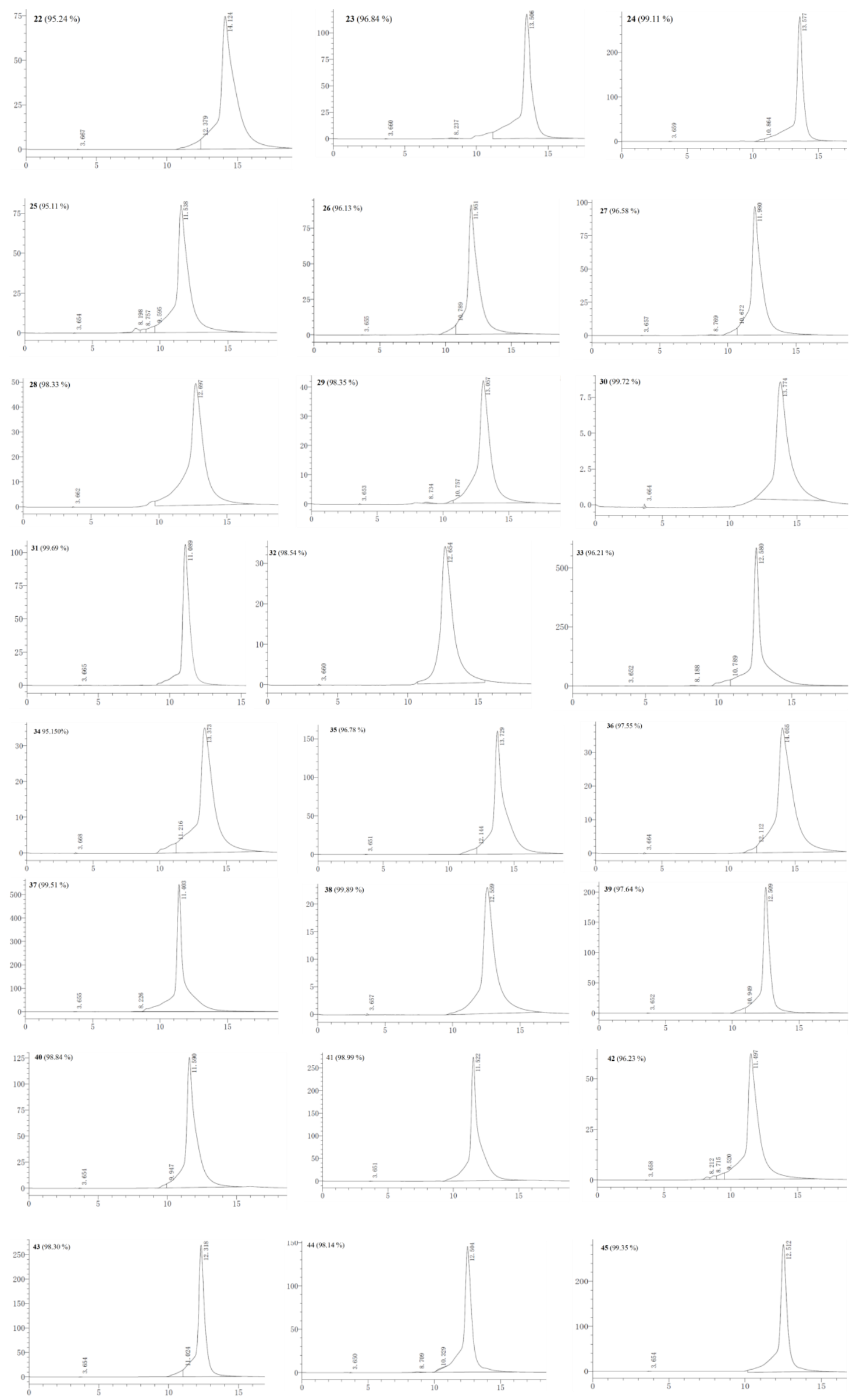

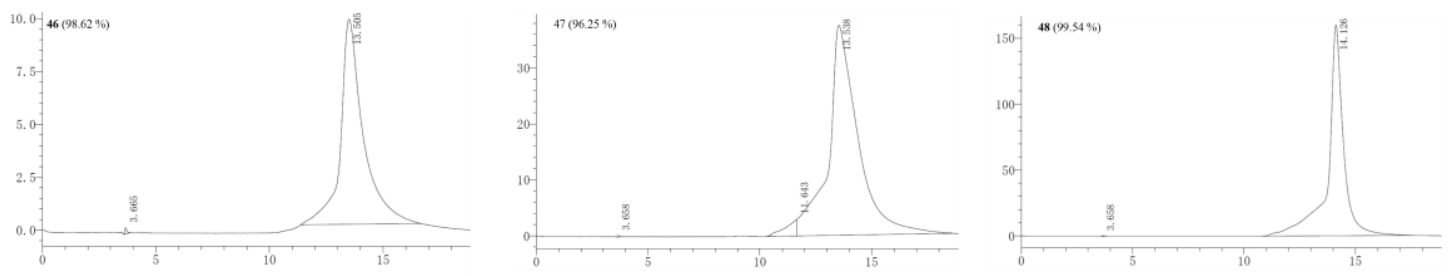

3) HPLC analysis of compounds $\mathbf{4 1 - H}(0.8 \mathrm{ml} / \mathrm{min}, 94 \% \mathrm{MeOH})$

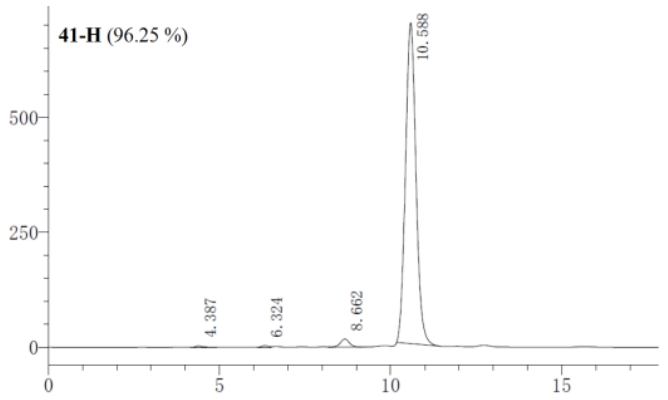

